\title{
Melter Viewing System for Liquid-Fed Ceramic Melters
}

\author{
J. H. Westsik, Jr. \\ B. B. Brenden
}

January 1988

Prepared for the U.S. Department of Energy under Contract DE-AC06-76RLO 1830

Pacific Northwest Laboratory

Operated for the U.S. Department of Energy

by Battelle Memorial Institute 


\title{
DISCLAIMER
}

This report was prepared as an account of work sponsored by an agency of the United States Government. Neither the United States Government nor any agency thereof, nor Battelle Memorial Institute, nor any of their employees, makes any warranty, expressed or implied, or assumes any legal liability or responsibility for the accuracy, completeness, or usefulness of any information, apparatus, product, or process disclosed, or represents that its use would not infringe privately owned rights. Reference herein to any specific commercial product, process, or service by trade name, trademark, manufacturer, or otherwise, does not necessarily constitute or imply its endorsement, recommendation, or favoring by the United States Government of any agency thereof, or Battelle Memorial institute. The views and opinions of authors expressed herein do not necessarly state or reflect those of the United States Government or any agency thereof, or Battelle Memorial Institute.

\author{
PACIFIC NORTHWEST LABORATORY \\ operated by \\ BATTELLE MEMORIAL INSTITUTE \\ for the \\ UNITED STATES DEPARTMENT OF ENERGY \\ under Contract DE-AC06-76RLO 1830
}

\begin{tabular}{|c|c|}
\hline \multicolumn{2}{|c|}{ Printed in the United States of America } \\
\hline \multicolumn{2}{|c|}{ Available from } \\
\hline \multirow{2}{*}{\multicolumn{2}{|c|}{$\begin{array}{l}\text { National Technical Information Service } \\
\text { United States Department of Commerce }\end{array}$}} \\
\hline & \\
\hline \multicolumn{2}{|c|}{5285 Port Royal Road } \\
\hline \multicolumn{2}{|c|}{ Springfield, Virginia 22161} \\
\hline \multirow{2}{*}{\multicolumn{2}{|c|}{$\begin{array}{l}\text { NTIS Price Codes } \\
\text { Microfiche } A 01\end{array}$}} \\
\hline & \\
\hline \multicolumn{2}{|c|}{ Printed Copy } \\
\hline & Price \\
\hline Pages & Codes \\
\hline 001-025 & A02 \\
\hline 026-050 & $\mathrm{A} 03$ \\
\hline 051-075 & $A 04$ \\
\hline $076-100$ & A05 \\
\hline 101-125 & AD6 \\
\hline 126-150 & $\mathrm{A} 07$ \\
\hline $151-175$ & $\mathrm{~A} 0 \mathrm{~B}$ \\
\hline $176-200$ & A09 \\
\hline 201.225 & A010 \\
\hline $226-250$ & A011 \\
\hline 251-275 & A012 \\
\hline 276-300 & $\mathrm{A} 013$ \\
\hline
\end{tabular}


FOR LIOU10-FED CERAMIO MELTERS

J. H. Westsik, Jr.

B. B. Brender

January 1988

Prepared for

the 1.3 . Department of Energy

under Contract DE-ACO6-76RLO 1930

Pacific Northwest Laboratory

Richtand, Washington 99352 
$\pm$ 


\section{SUMMARY}

Melter viewing systems are an integral component of the monitoring and control systems for liquid-fed ceramic melters. The Pacific Northwest Laboratory (PNL) has designed cameras for use with glass melters at PNL, the Hanford Waste Vitrification Plant (HWVP), and West Valley Demonstration Project (WVDP). This report is a compilation of these designs. Operating experiences with one camera designed for the PNL melter are discussed.

The cameras have been designed to provide images of the melter interiors while protecting the optical components from the harsh environment of corrosive chemicals, high temperatures, and high radiation fields. Critical components are fabricated of corrosion-resistant and radiation-hardened materials. Two separate cooling-air paths are used in all the designs to maintain camera temperatures within an acceptable temperature range. The electronic components of the cameras are placed outside the melter to further protect them.

A camera has been fabricated and tested on the High-Bay Ceramic Melter (HBCM) and the Pilot-Scale Ceramic Melter (PSCM) at PNL. The camera proved to be an effective tool for monitoring the cold cap formed as the feed pool developed on the molten glass surface and for observing the physical condition of the melter. Originally, the camera was wilt to operate using the visible light spectrum in the melter. It was later modified to operate using the infrared (IR) spectrum. In either configuration, the picture quality decreases as the size of the cold cap increases. Large cold caps cover the molten glass, reducing the amount of visible light and reducing the plenum temperatures below $600^{\circ} \mathrm{C}$. This temperature corresponds to the lowest level of blackbody radiation to which the video tube is sensitive.

The camera has been tested in melter environments for about $1900 \mathrm{~h}$. The camera has withstood mechanical shocks and vibrations. The cooling system in the camera has proved effective in maintaining the optical and electronic components within acceptable temperature ranges.

A new camera has been designed with improvements that evolved from the operating experiences with the first camera. Most of the optical components have been moved out of the harsh environment of the melter plenum. This 
reconfiguration results in a simpler, easier to repair camera housing. The canera housing is also more upright than previous designs to reduce interference with other equipment on the melter. 


\section{ACXNOWLEDGMENTS}

We thank the numerous people who participated in the design and development of these melter viewing systens. D. N. Berger, R. D. Thornhill, K. Austin, J. 8. Cattaneo, J. H. Hofweber, L. B, Hutchens, X. E. Keene, H. L. Meteler, M. D. Ripplinger, M. Studd, S. L. Trent, D. J. Yeager, and R. Zama developed the detailed designs for the cameras. S. M. Barnes, S. D. Halstead, K. E. Eliason, F. E. Haun, and $W .0$. Heath contributed to the development, testing and documentation of the cameras. 


\section{CONTENTS}

SUMMARY ..............................

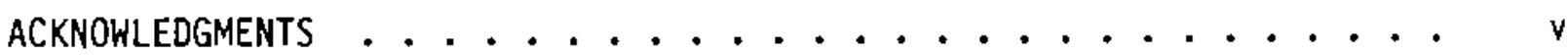
ACRONYMS .......................... ix

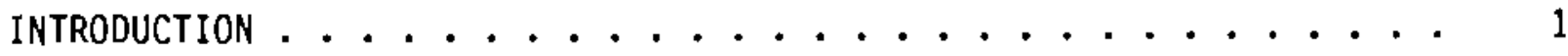

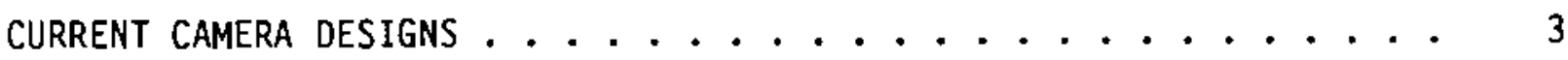

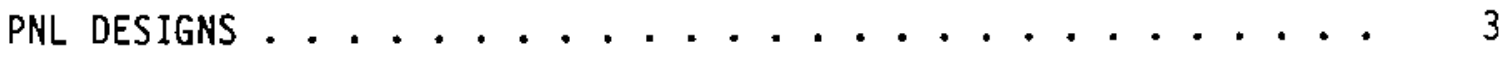

HBCM/PSCM Camera ................. 3

RLFCM Camera ....................... 7

Electronics ....................... 8

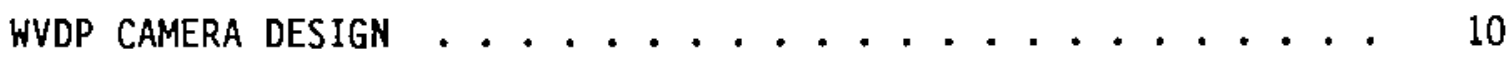

HWVP CAMERA DESIGN ............................... 10

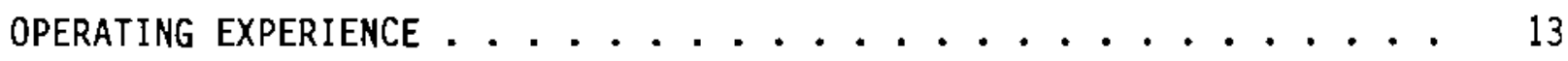

VISIBLE LIGHT CONFIGURATION . . . . . . . . . . . 13

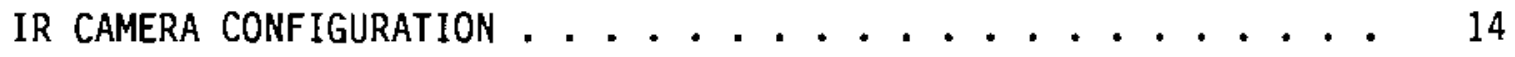

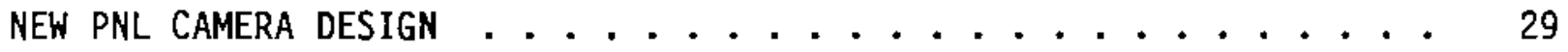

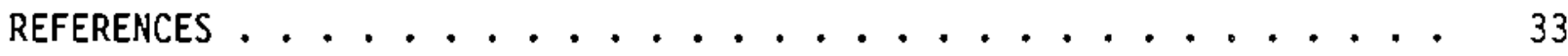

APPENDIX A: DETAILED DRAWINGS OF THE HBCM/PSCM CAMERA $\ldots \ldots \ldots$. . . A.1

APPENDIX B: DETAILED DRAWINGS OF THE RLFCM CAMERA . . . . . . . B.1

APPENDIX C: CONCEPTUAL DESIGN FOR THE WVDP CAMERA . . . . . . . c.1

APPENDIX D: CONCEPTUAL DESIGN FOR THE HWVP CAMERA $\ldots \ldots \ldots . \ldots . \ldots$

APPENDIX E: NEW PNL CAMERA DESIGN ................ . . E.1 


\section{FIGURES}

1 Schematic of HBCM/PSCM Cantera ................4 4

2 Spectral Response of Video Tube and Emittance of Blackbodies at Typical Melter Temperatures ......... 6

3 Schenatic of RLFCM Canera .............. 7

4 Schematic of WVDP Canera ................ 11

5 Location of Melter Insturmentation During PSCM-21 ...... 15

6 Melter Interior Showing Bubbler Probe, Feed Nozzle South Electrode, and Thermowell ............... 16

7 Melter Interior Seven Minutes After Figure $6 \ldots 17$

8 Gray-\$cale Conversion of Figure $6 \ldots, \ldots, \ldots$

9 Melter Interior During Overfeeding ........... 19

10 Melter Interior 2 Minutes After Feed Turned off ....... 20

11 Melter Interior 12 Minutes After Feed Turned off . . . . . . 21

12 Me1ter Interior 22 Minutes After Feed Turned off $\ldots \ldots 22$

13 Melter Interior 32 Minutes After Feed Turned off ....... 2?

14 Melter Interior 42 Minutes After Feed Turned off . . . . . 24

15 Plenum Temperatures for Run PSCM-16 ............ 27

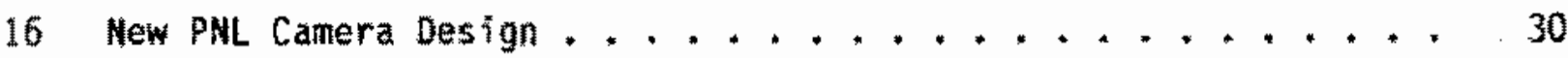


$+$ 
ACRONYMS

$\begin{array}{ll}\text { ADS } & \text { Air-Displacement Slurry } \\ \text { FRG } & \text { Federal Republic of Germany } \\ \text { HBCM } & \text { High-Bay Ceramic Melter } \\ \text { HWVP } & \text { Hanford Waste Vitrification Plant } \\ \text { IR } & \text { infrared } \\ \text { LFCM } & \text { Liquid-Fed Ceramic Melter } \\ \text { NTSC } & \text { National Television System Committee } \\ \text { NWTP } & \text { Nuclear Waste Treatment Program } \\ \text { PNL } & \text { Pacific Northwest Laboratory } \\ \text { PSCM } & \text { Pilot-Scale Ceramic Melter } \\ \text { RGB } & \text { red green blue } \\ \text { RLFCM } & \text { Radioactive Liquid-Fed Ceramic Melter } \\ \text { SCFM } & \text { Standard Cubic Feet Per Minute } \\ \text { SODA } & \text { Small Optical Design and Analysis } \\ \text { SRL } & \text { Savannah River Laboratory } \\ \text { WVDP } & \text { West Valley Demonstration Project }\end{array}$





\section{INTRODUCTION}

Liquid-fed ceramic melters (LFCM) are being developed for immobilizing radioactive liquid wastes in a glass matrix. The Nuclear Waste Treatment Program (NWTP) and its predecessors at the Pacific Northwest Laboratory (PNL) have the responsibility to develop the technology necessary to implement this process for the treatment of radioactive wastes. A melter viewing system is an integral component of the control system for the LFCM process.

In the LFCM process, a slurry of the radioactive wastes and finely crushed glass is poured onto a pool of molten glass in the melter. The liquids boil of $f$ and the chemicals decompose to their oxides before being absorbed by the molten glass. At sufficiently large feed rates, a "cold cap" forms on the surface of the glass. Most of the decomposition reactions take place in this cold cap. The cold cap is advantageous because it reduces the volatilization of species from the hot glass, and it maximizes the vitrification processing rate. However, if the cold cap becomes too large, the melting process becomes unstable. The cold cap may bridge across the walls of the melter such that the cold cap may lose contact with the molten glass, thereby reducing heat transfer and slowirg the processing rate. Pressurizations are also more vigorous and frequ. 't. Thus it is important to optimize the cold cap size to maximize the production rate without extending into potentially unstable operating conditions.

Another operating condition of concern is the formation of glass foam. This foam increases the volume of material in the melter to levels that could damage equipment and insulates the cold cap from the molten glass, thus reducing the processing rate.

The size and condition of the cold cap, the presence of foam, and the general physical condition of the melter have historically been determined via visual observation. The nonradioactive melters at PNL have view ports that allow the operators to look directly into the melter. Melters for processing radioactive wastes cannot be viewed directly because of the need to place the melters in shielded facilities. Therefore, remote viewing techniques are needed to look into the melter cavity and observe the condition of the cold cap and the interior melter components. Other instrumentation 
was evaluated in a previous study to determine whether it could provide the same infomation as viewing the glass surface but did not prove to be as explicit (Barnes, Westsik, and Wise 1985; Westsik et al. 1985). The Radioactive Liquid-Fed Ceramic Melter (RLFCM) at PNL was operated successfully for about $2-1 / 2$ years without a melter viewing system. While visual may not be necessary on a continuous basis, it does provide an excellent method to verify conditions within the melter and will enhance control and perhaps increase efficient melter operation.

This report discusses the designs of the melter viewing systems used at PNL and the designs prepared by PNL for WVDP and HWVP. Operating experiences with the PNL system are presented. Based upon these operating experiences, a new camera design has been prepared for use at PNL. 


\section{CURRENT CAMERA DESIGNS}

Melter viewing systems are designed to provide an image of most of the melter surface while protecting the necessary lenses, mirrors, and electronics from the harsh environment of corrosive chemicals, high temperatures, and high radiation fields. The optical components and their housing are referred to here as the "camera." Savannah River Laboratory (SRL) designed the first camera system for remote viewing of the melter surface (Heckendorn 1983, 1986). Pacific Northwest Laboratory incorporated features of the SRL design into cameras built for the High-Bay Ceramic Melter (HBCM) and the Pilot-Scale Ceramic Melter (PSCM) and for the RLFCM. The Laboratory is also designing cameras for use at WVDP and at HWVP.

\section{PNL DESIGNS}

The first camera built at PNL was designed and fabricated for the HWVP (Siemens et al. 1985). This camera was tested and evaluated on the HBCM and PSCM melters. This basic camera design was then modified for the RLFCM to incorporate features necessary for the remote, radioactive environment.

\section{HBCM/PSCM Camera}

Figure 1 shows a schematic of the $\mathrm{HBCM} / \mathrm{PSCM}$ camera. The camera was designed to be installed in a corner of the melter. Because the camera was to be in a vertical nozzle, the objective lenses were offset 30 degrees from vertical to look down and across the molten glass surface. Outside the melter, the optical path bends 90 degrees so that the video tube is not in the direct path of radiation from the glass. Detailed drawings of the camera are shown in Appendix A.

Two air streams are used to cool the camera. The first enters the camera body behind the video tube. Cooling the video tube is important because the electronics are particularly susceptible to heat. After flowing past the video tube, the air flows through holes in the iris/filter holder, down through the center optic-path tube, across the mirrors in the camera nose, and along the wide-angle lens housing. The air then flows back up in the annulus between the optic-path tube and the outer housing and exhausts into the cell. Design 


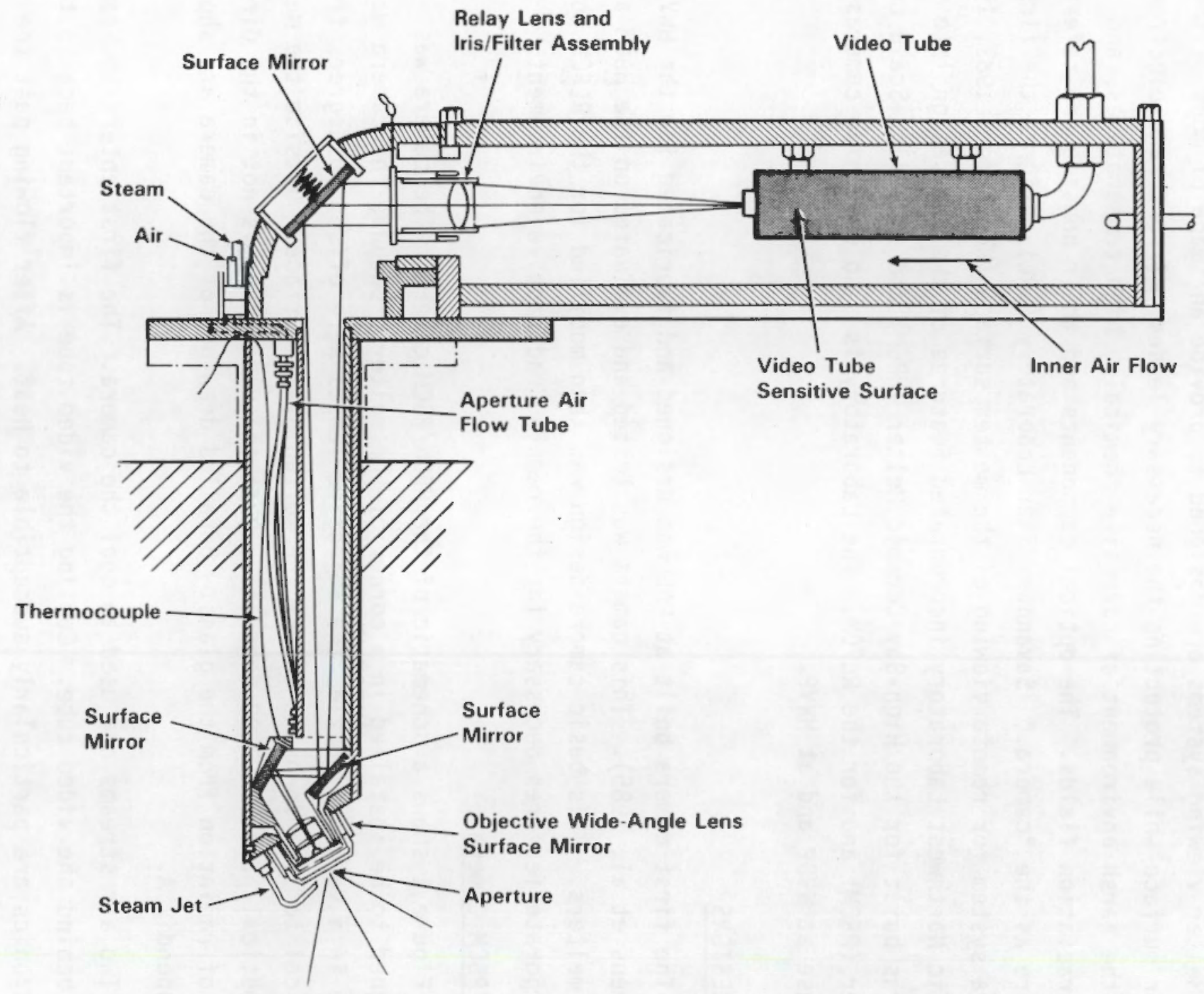

FIGURE 1. Schematic of HBCM/PSCM Camera 
calculations show this flow pattern keeps the lens assembly cooler than with the air flow reversed. The second air stream flows through flexible tubing to the face of the wide-angle lens and out into the melter through the aperture. This flow path keeps the face of the lens cool and helps sweep off the gas and particulates away from the camera nose. It is important that this cooling air be filtered to remove oils and particulates that could damage the optics and electronics of the camera.

During the initial testing, particulates and condensates obscured the aperture of the camera. A steam jet that blows across the aperture was therefore added. Short $(<10-$ second) blasts of steam once a day proved effective in keeping the aperture clear. Because the steam blasts caused pressurization of the melter, one-second blasts were recommended (Siemens et al. 1985). The stean line was not needed during PSCM runs 21 and 22.

The camera has been designed to be mounted vertically in one corner of the melter and to view the surface of the melt at a distance of about $46 \mathrm{~cm}$. Since the surface to be viewed is somewhat larger than $60 \mathrm{~cm} \times 120 \mathrm{~cm}$, the camera objective must have a very large field of view. An eyepiece-type lens with a 70-degree field of view and a $16-\mathrm{mm}$ focal length was chosen. The image formed by this lens is relayed to the sensitive surface of the video tube using an achromat with a focal length of $22.00 \mathrm{~cm}$, located abc $: 26.2 \mathrm{~cm}$ in front of the video-tube sensitive surface.

Because the PSCM and $\mathrm{HBCM}$ melters do not process radioactive materials, a standard commercial lens could be used for the objective lens. However, the cement used with one pair of elements in this commercial lens deteriorates when the lens becomes too hot. To avoid the resulting deterioration of the image, this lens must first be taken apart and the cement removed. The lens can then be reassembled without cement.

Originally, the camera was designed to operate using the visible light spectrum. This was possible when the plenum heaters (as used at SRL) or the exposed molten glass would illuminate the melter cavity. The camera included a filter to remove the near-IR light and an iris assembly to reduce the intensity of the visible light. The visible spectrum is of limited value, however, when there are no plenum heaters and when the cold cap covers the 
glass surface. Therefore, the iris and visible-light-transmitting filter were replaced with an IR-transmitting filter. Figure 2 shows the response of the video tube, the light transmitted by the two types of filters, and the radiation emitted by a blackbody at temperatures expected in a glass melter (Siegel and Howell 1981).

\section{RLFCM Camera}

The RLFCM camera is very similar in design to the HBCM/PSCM camera. The camera is intended to be placed in a nozzle in a corner of the melter.

As shown in Figure 3, the RLFCM camera has the same "L" shape as the cold camera. However, the lenses and mirrors in the nose are rotated 180

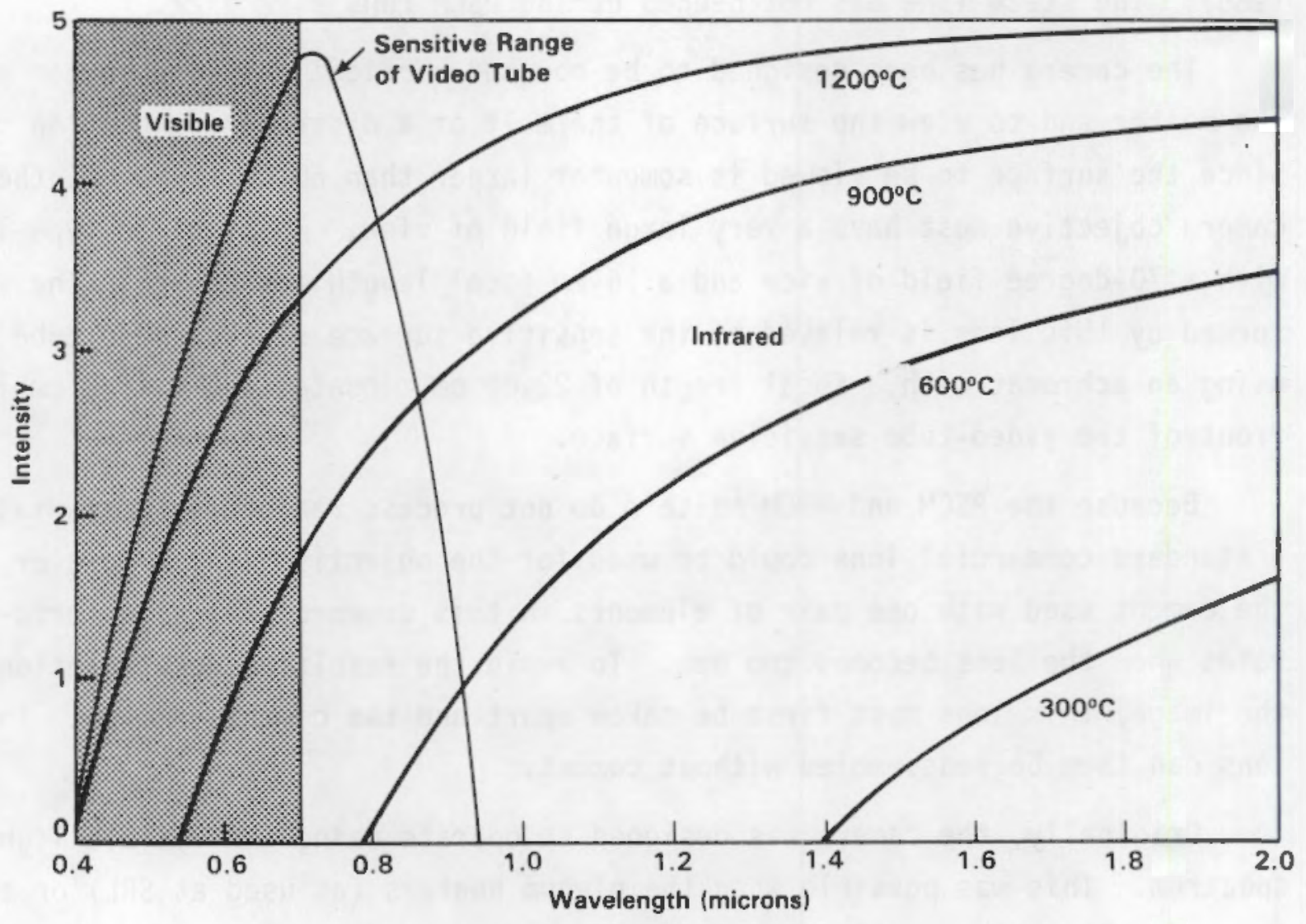

FIGURE 2. Spectral Response of Video Tube and Emittance of Blackbodies at Typical Melter Temperatures 


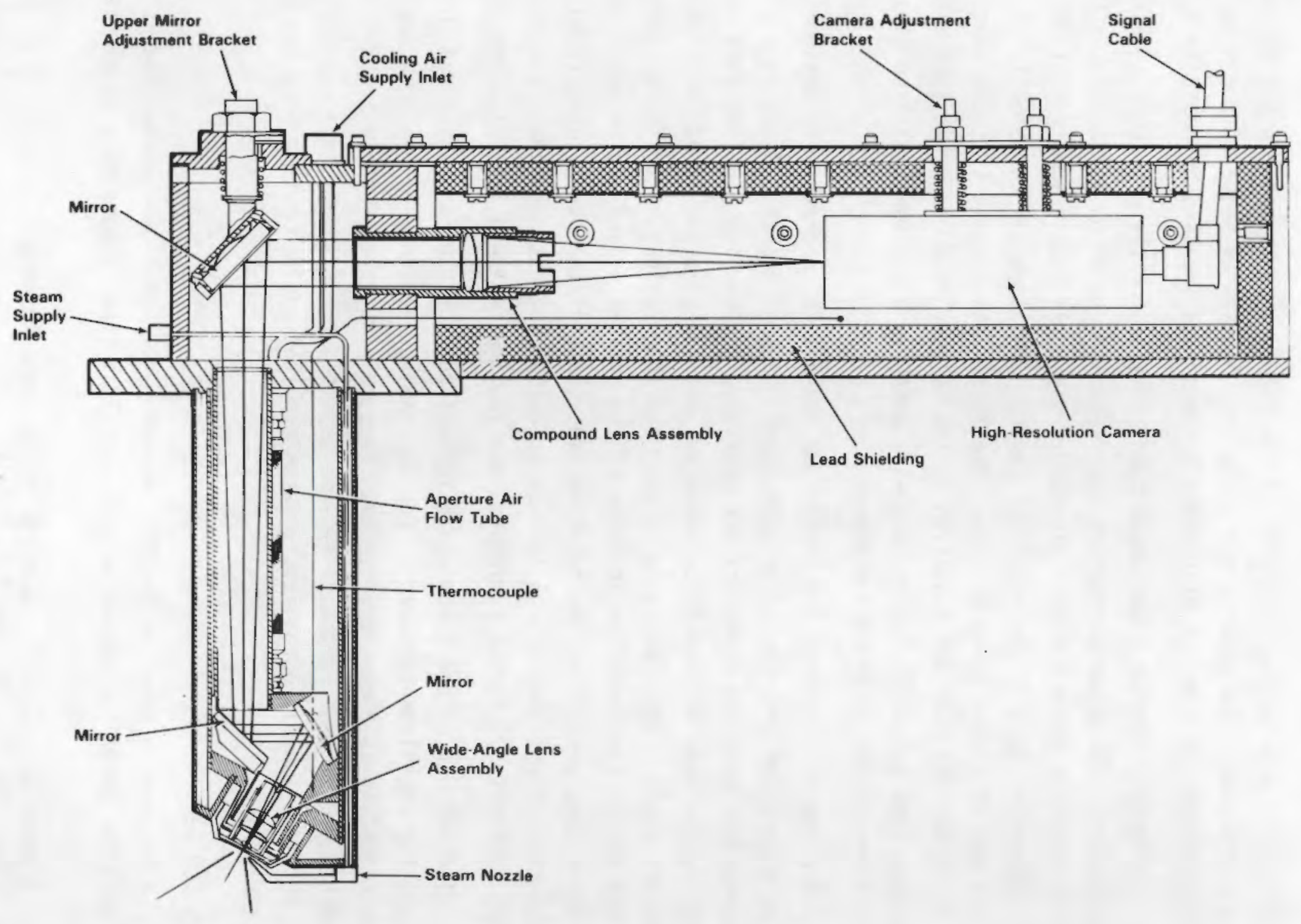

FIGURE 3. Schematic of RLFCM Camera 
degrees. Lead shielding is placed inside the housing to protect the sensitive video tube. The cooling-air paths are the same as those of the HBCM/PSCM camera. Detailed drawings of the RLFCM camera are included in Appendix B.

The optics for the camera have been modified for the remote, radioactive application. The upper mirror has been remounted to allow adjustments with a manipulator. A three-element, air-spaced objective lens assembly replaces the commercial lens of the HBCM/PSCM camera. The lens has the same focal length and 70-degree field of view. The first lens element is fused quartz to withstand the heat and radiation in the melter. The other two lens elements are made from Schott ${ }^{(a)}$ BK-7-G-18 glass, which is a cerium-stabilized glass that is resistant to radiation damage.

The lenses for the RLFCM, WVDP, and the new PNL cameras were designed using a computer program called SODA (Small Optical Design and Analysis). (b) The designer provides inputs of the indices of refraction, lens-surface location, approximate lens-surface curvature, and the size and location of the entrance pupil. The glasses to be used and the wavelengths to be considered in the design are specified in terms of the indices of refraction used. The designer also prescribes the relative importance of the aberrations to be corrected. These aberrations include spherical aberrations, coma, astigmatism, distortion, etzval curvature, and longitudinal and lateral color.

The outputs of the program are the optimum surface curvatures and thicknesses for each lens component. For the cameras designed at PNL, the optics were optimized as a complete system. Thus, aberrations of the objective lens assembly are reduced by the relay lens assembly. Individual lens assemblies are not individually optimized, a technique that would not result in the best system design.

\section{Electronics}

A Matsushita Newvicon $\$ 411 \mathrm{~g}^{(\mathrm{C})}$ extended near-IR video-camera tube is used in both the HBCM/PSCM and RLFCM systems. This tube is sensitive to spectral

(a) Trademark of Schott Glaswerke, Mainz, West Germany.

(b) Copyright 1985 by Donald W. Small.

(c) Trademark of Matsushita Electric Corp. of America, Secaucus, New Jersey. 
energy extending from $0.4 \mu \mathrm{m}$ to $0.95 \mu \mathrm{m}$ (see Figure 2). The video tube has been shown to withstand radiation doses to $3 \times 10^{8} \mathrm{R}$. Improved image quality is obtained by restricting the spectral range to either the visible or the IR portion of the spectrum. Because the molten glass surface is viewed in its own radiation, somewhat cooler surfaces can be seen using the IR spectrum extending from $700 \mathrm{~nm}$ to $950 \mathrm{~nm}$. Therefore, an optical filter is used between the relay lens and the video tube to remove the visible light spectrum. A separate remote control unit isolates much of the electronics from the radiation field.

Signals from the control unit can then be viewed directly on a video monitor, recorded on video tape, or further processed. The HBCM/PSCM melterviewing system includes a gray-scale-to-color converter that classifies the black and white signal into eight brightness bands. When processing an IR image, the bands can be calibrated to span-defined temperature ranges. The areas of the bands can also be determined and displayed on a digital meter. To aid in calibrating the image analyzer, we replaced the factory knobs with 0-100 turn dials. An RGB (red, green, blue) output from the image analyzer is displayed on an RGB monitor either as a black and white picture or in color, with the colors indicating specific brightness bands. The RLFCM system has a gray-scale-to-color converter but does not include the image-analyzing capabilities.

To record the RGB color pictures on video tape, the RGB outputs must first pass through a color encoder which converts the signal to the standard National Television System Committee (NTSC) format. The signals are then recorded on a video cassette recorder, which can record up to one hour of video on 3/4-inch tapes. If it is necessary to document an entire melter run, recording in the VHS format ${ }^{(a)}$ with longer and cheaper tapes should be considered.

(a) Trademark of Victor of Japan, Ltd., Yokahama City, Japan. 


\section{WVDP CAMERA DESIGN}

A melter viewing system has also been designed for use in WVDP. The design places the video camera outside the melter cell in a region shielded from radiation (See Figure 4). The video camera can be serviced or replaced without exposure to high radiation levels. To place the camera outside the cell, two additional relay lenses and two mirrors were used. These were designed to fit into a shield plug with an offset optical path. Aside from this shield plug and its associated optics, the remainder of the periscope is essentially the same design as that used for the RLFCM. The prescriptions for the lenses have been changed, however, to optimize to the dimensions of the WVDP cell. The conceptual design for the camera is shown in Appendix $C$.

\section{HWVP CAMERA DESIGN}

The camera designed for the HWVP is very similar to the design for the RLFCM camera at PNL. They differ primarily in the location and type of connectors for the electrical, cooling air, and steam services. The conceptual design for the camera is shown in Appendix D. 


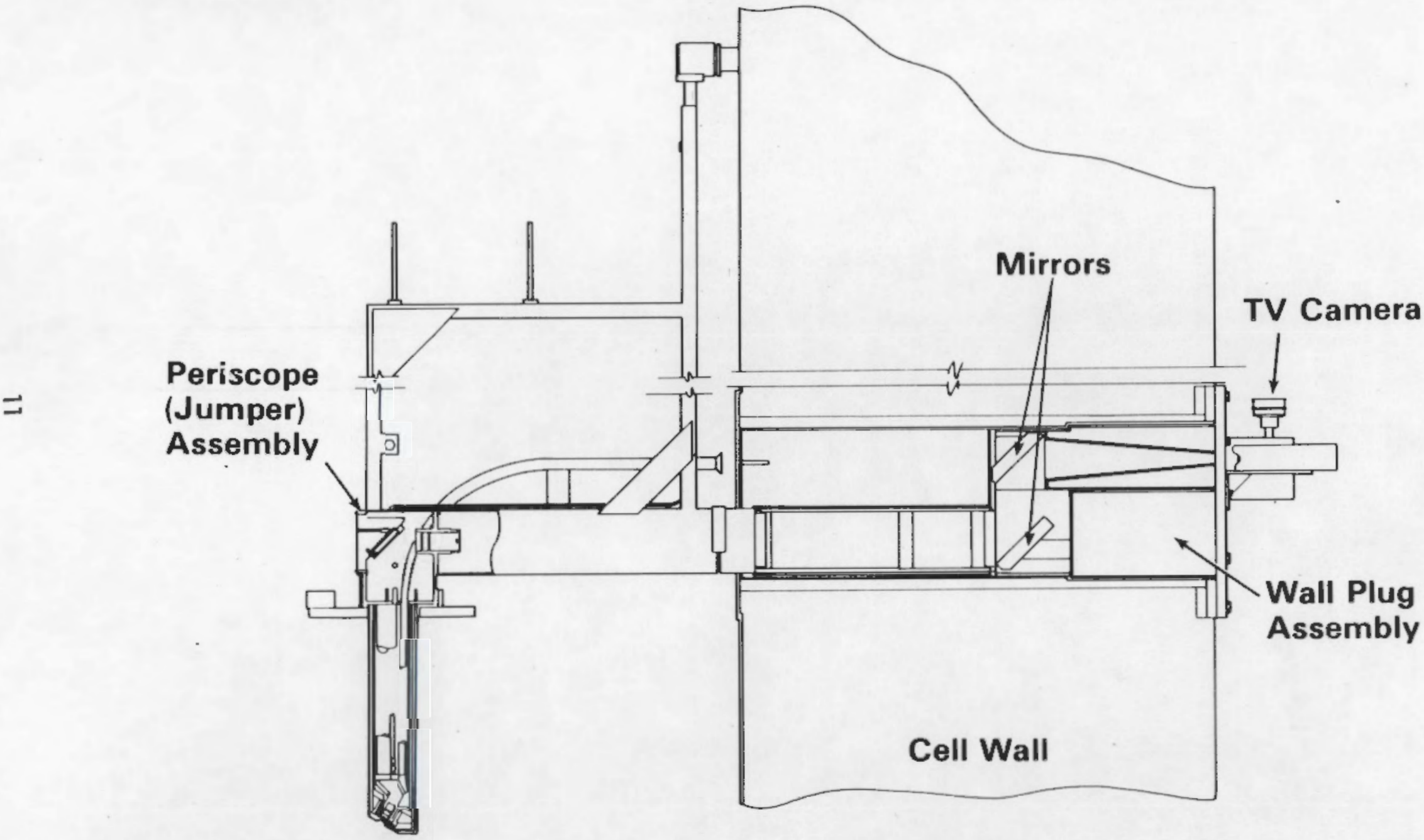

FIGURE 4. Schematic of WVDP Camera 


\section{OPERATING EXPERIENCE}

The melter viewing system was developed initially to operate using the visible light spectrum. The camera was later modified to operate using the near-IR spectrum. Operating experience with both configurations is discussed below.

\section{VISIBLE LIGHT CONFIGURATION}

Initial development of the $\mathrm{HBCM} / \mathrm{PSCM}$ camera has been reported previously by Siemens et al. (1985) and is summarized here. During the development period, the steam jet was added to facilitate removal of splashes and condensates that were obscuring the aperture in the camera nose. The iris and IR filter were inserted into the optical path to improve the clarity of pictures displayed. The gray-scale-to-color converter was employed to further improve the picture clarity. The camera was shown to withstand the vibrations and shocks of bumping into objects during installation. To remove distortion in the pictures caused by the power cables supplying power to the melter, an isolation transformer was inserted into the power supply line to the camera and monitor. Cooling air maintained temperatures near the nose of the camera at $127^{\circ} \mathrm{C}$ during idling in the $\mathrm{HBCM}$. F $-w$ rates were 18 SCFM through the camera body and 1.7 SCFM through the camera aperture.

The camera was installed in the HBCM for $1155 \mathrm{~h}$ in a long-term test of the optics and camera housing. No deterioration of camera performance was detected.

The camera was then used during the $320 \mathrm{~h}$ of the PSCM-19 melter experiment in August 1984 (Burkholder, Jarrett, and Minor 1985). All components of the system worked well. Cooling air at 3 SCFM was sufficient to keep the measured camera temperature below $100^{\circ} \mathrm{C}$. Steam cleaning kept the aperture free of visible obstructions. Picture quality was dependent upon the cold cap size; larger cold caps decreased illumination, which resulted in poorer picture quality. 


\section{IR CAMERA CONFIGURATION}

Following the melter test designated PSCM-19, the camera was modified to utilize the near-IR rather than the visible light spectrum. The iris and IR filter were replaced by a visible light filter with a cutoff of $0.7 \mu \mathrm{m}$. The camera was then used during portions of melter runs PSCM-21 and PSCM-22 (Burkholder and Jarrett 1986; Burkholder, Jarrett, and Minor 1986).

Installation of the IR camera for the PSCM-21 run was delayed because of difficulties in cooling the lens-and-mirror portion of the camera that extends into the melter plenum. The lack of cooling caused the mirrors and one of the lens elements to break. Once an air leak was plugged and the broken optical components were replaced, the camera worked well. The camera was installed in the melter for a total of $311 \mathrm{~h}$. Temperatures measured near the lower mirrors were as high as $255^{\circ} \mathrm{C}$ during idling and as $10 \mathrm{w}$ as $77^{\circ} \mathrm{C}$ during melter operation.

For the PSCM-21 run, the camera was rotated to look at the southwest corner of the melter beneath the viewport such that the corner opposite the corner visible from the viewport could be observed (Figure 5). Video tapes were made of growth and burnoff of the cold cap, overfeeding, and the early stages of foaming. Figures 6 through 14 show photographs taken from the video tapes recorded during PSCM-21. The photos include large portions of the melter walls rather than the glass/cold cap surface. Only a quarter to a third of the melt surface is visible because the horizontal part of the camera extended between the feed nozzle and the bubbler tube (see Figure 5 ) such that the camera could not be rotated to look at more of the melt surface. From the perspectives of the camera and viewport, drifting of the cold cap along the melt surface could be observed. Neither the view from the camera nor from the viewport gives an accurate indication of the cold cap coverage in those areas that were not visible. It will therefore be difficult to use the IR camera to obtain quantitative data on the growth and consumption of the cold cap unless the entire melt surface can be viewed.

Figure 6 shows the melter interior at about 13:45 on June 6, 1985. The bubbler probe is clearly visible at the lower left; the feed nozzle is at the upper right, and the south electrode and glass thermowell are at the lower right. Hotter regions in general appear brighter in the photo. However, 


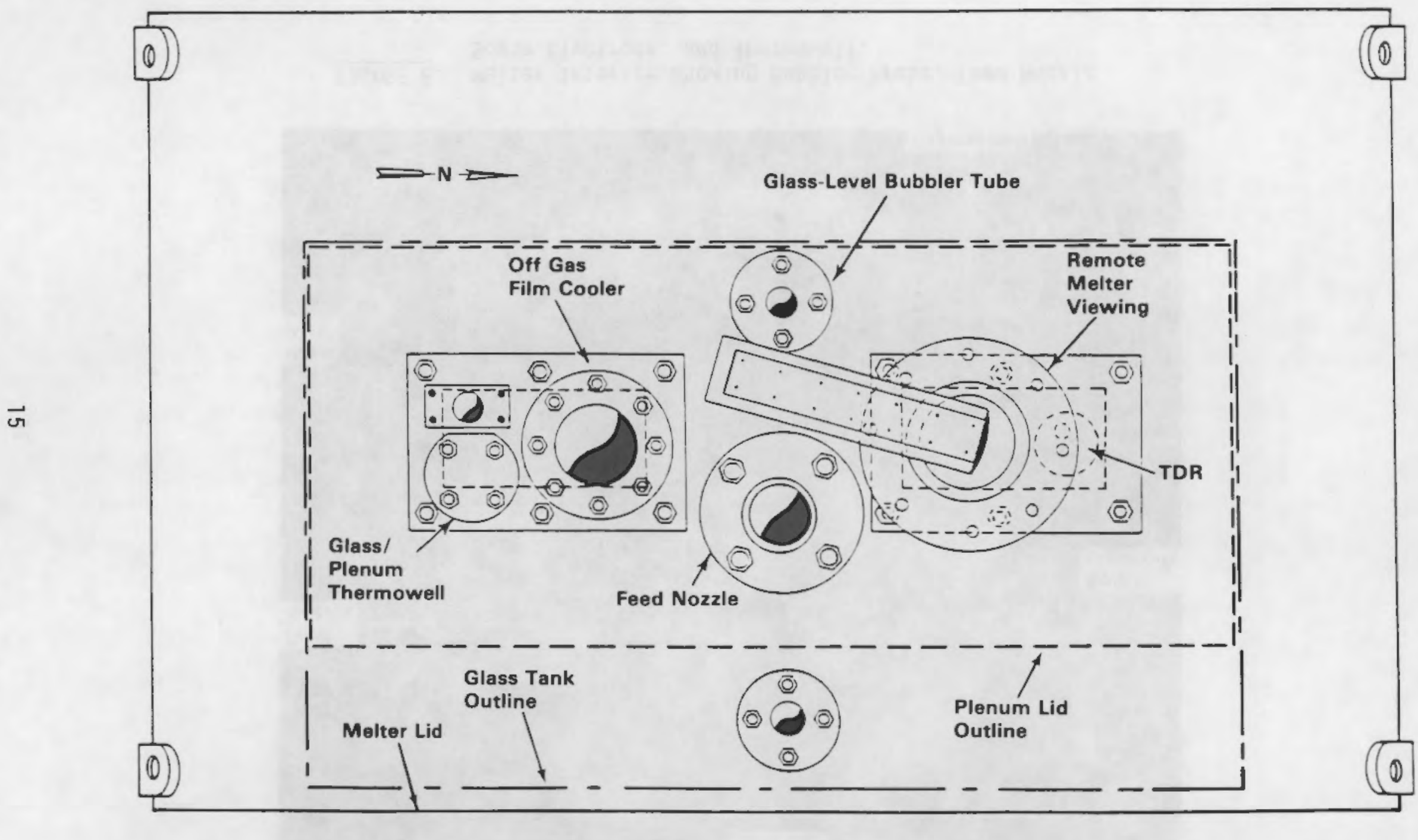

FIGURE 5. Location of Melter Instrumentation During PSCM-21 


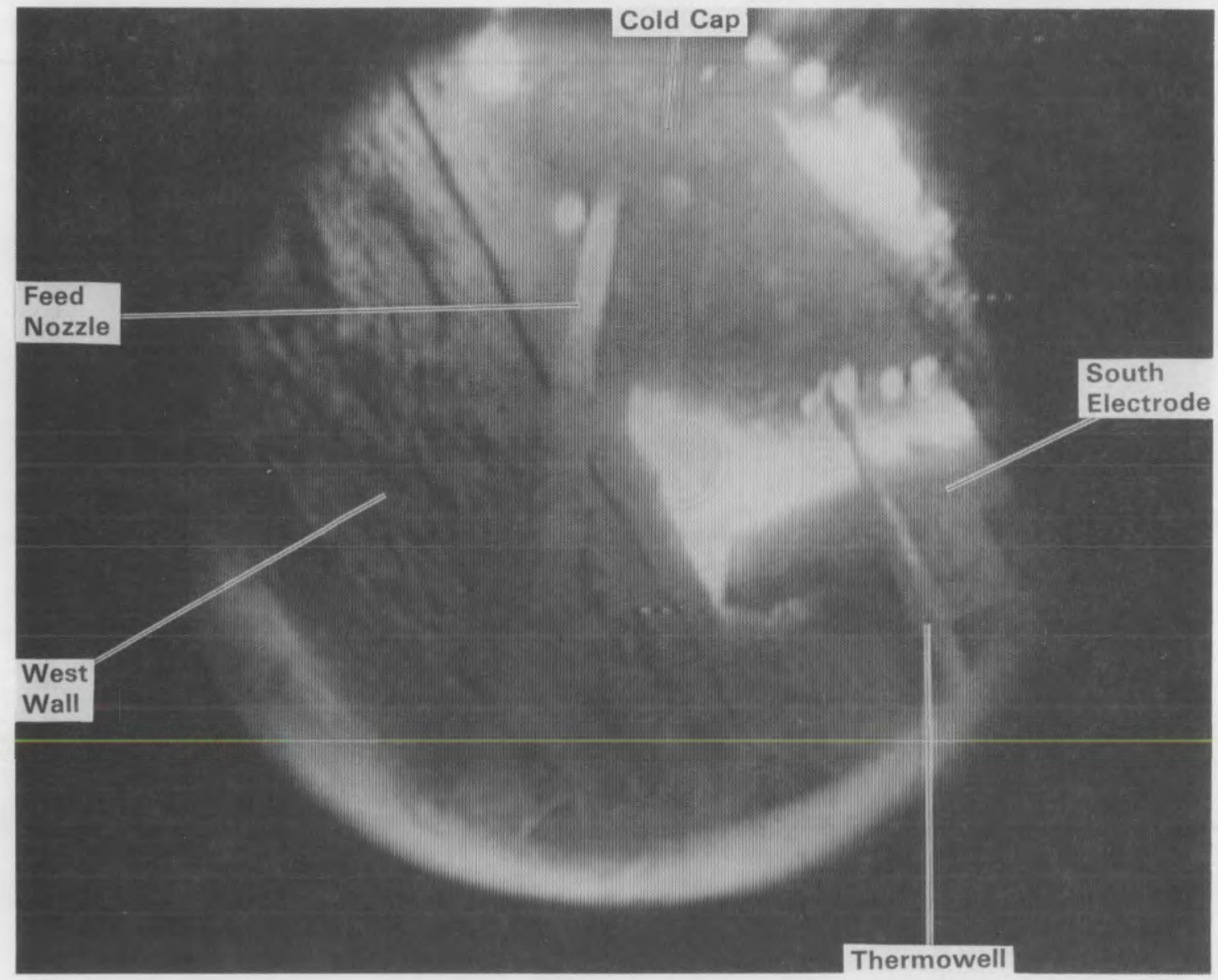

FIGURE 6. Melter Interior Showing Bubbler Probe, Feed Nozzle South Electrode, and Thermowell. 


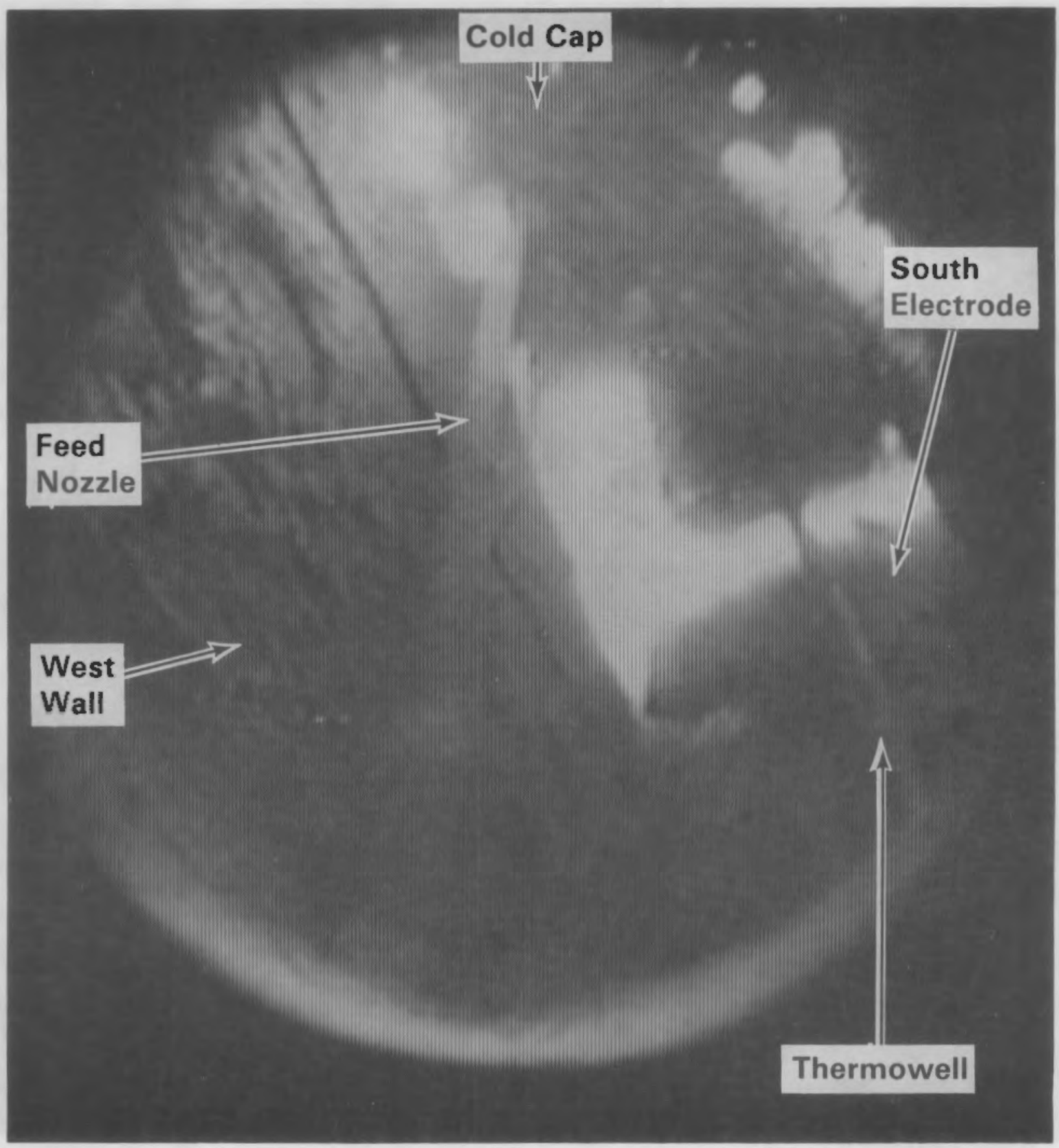

FIGURE 7. Melter Interior Seven Minutes After Figure 6. Note the absence of the pour stream at the tip of the nozzle. 


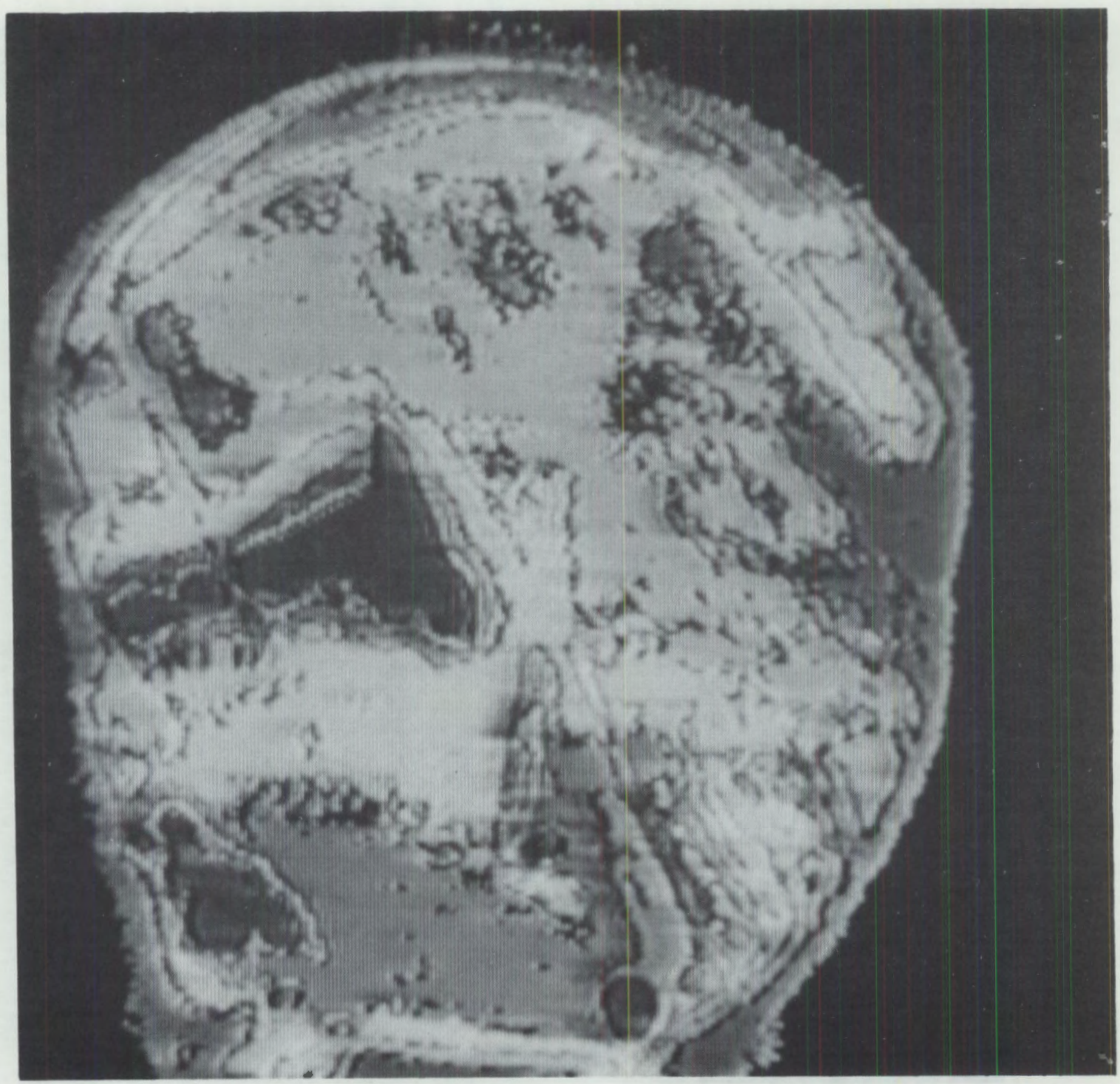

FIGURE 8. Gray-Scale Conversion of Figure 6 


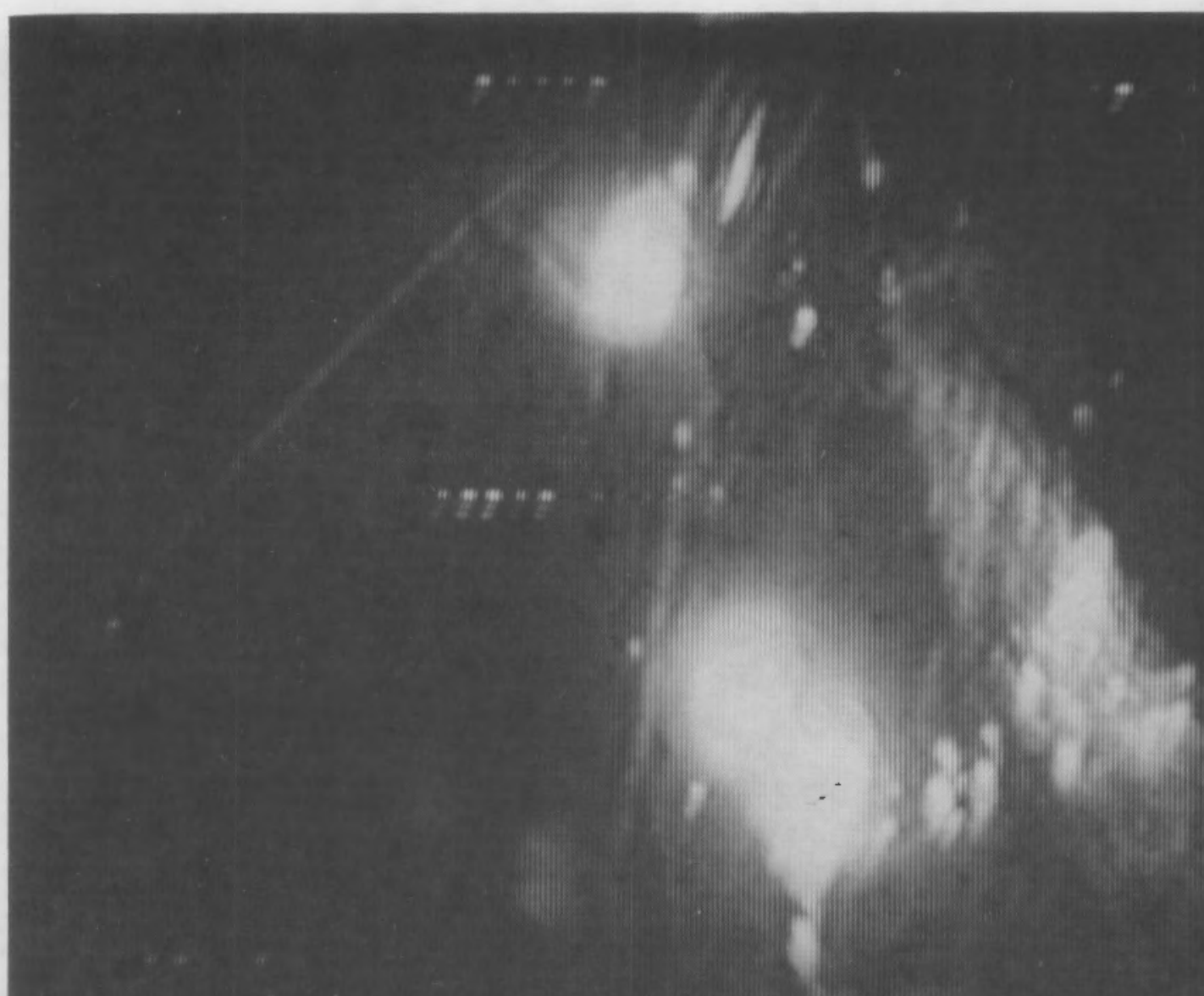

FIGURE 9. Melter Interior During Overfeeding 


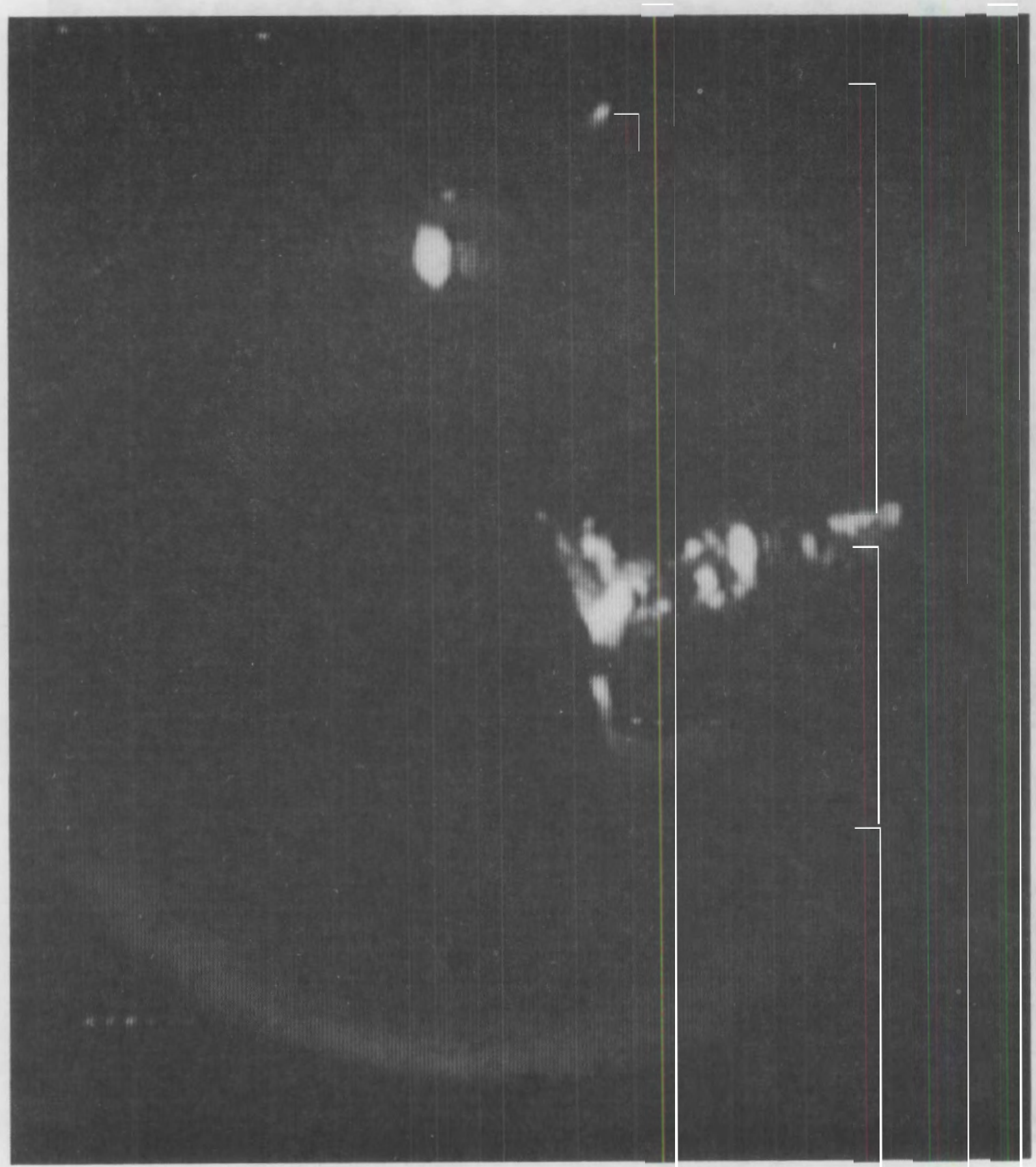

FIGURE 10. Melter Interior 2 Minutes After Feed Turned off 



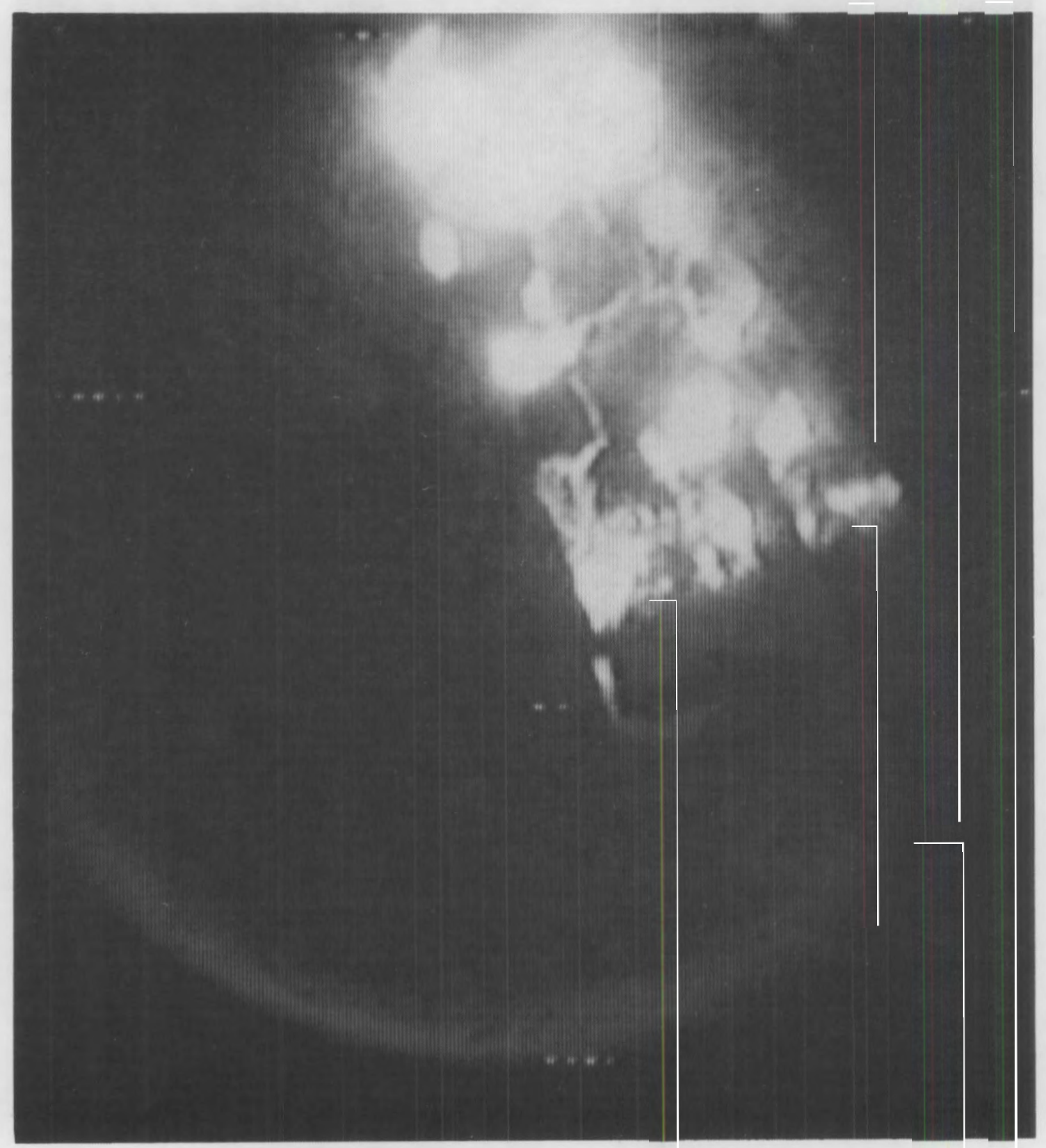

FIGURE 12. Melter Interior 22 Minutes After Feed Turned off 



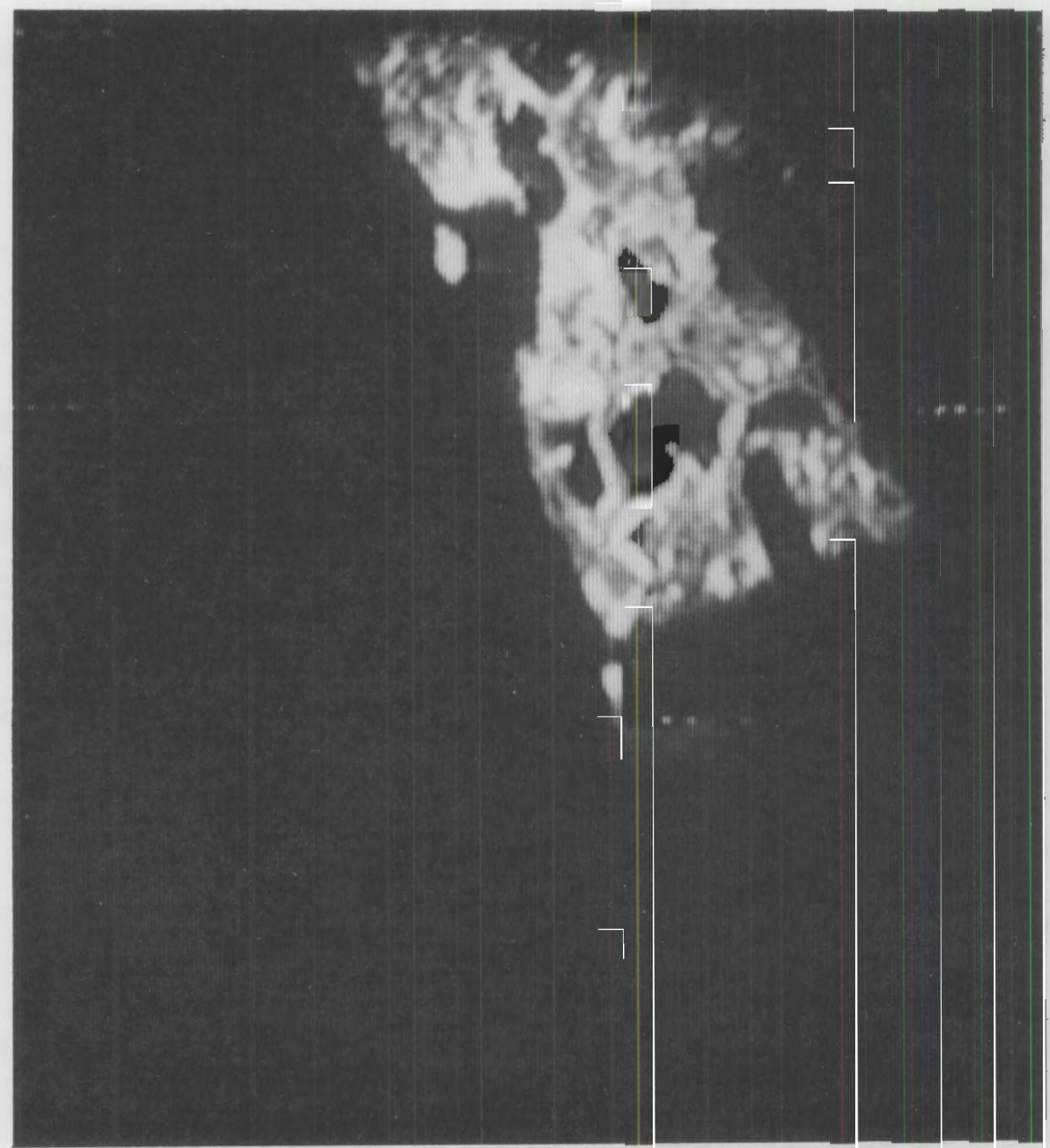

FIGURE 14. Melter Interior 42 Minutes After Feed Turned Off 
many surfaces reflect the light from the exposed hot glass, making the surfaces appear hotter than they really are. Thus, the feed stream pouring from the feed nozzle appears as a bright line extending beyond the tip of the feed nozzle, and the bubbles from the boiling slurry appear as bright circles on the cold cap surface. Figure 7 was taken about seven minutes after Figure 6 when the air-displacement slurry (ADS) pump was in its fill cycle such that there is no feed strean visible at the tip of the feed nozzle.

Figure 8 shows the effect of the gray-scale-to-color converter on the image taken 2 or 3 seconds after Figure 6 . (Note that Figure 8 is a black and white photograph of this conversion.) Whereas the conversion from black and white to the color band is reported to improve the picture quality for the visible light camera configuration, the gray-scale-to-color conversion appears to result in a loss of detail when using the near-IR spectrum (Siemens et al. 1985).

Figure 9 shows the melter during an intentional period of overfeeding at about $22: 2 \mathrm{D}$ on June 8,1985 . The interior is very dark except for several vents in the cold cap. The light streaks emanating from the top of the photo are the paths taken by glass particles emitted by a vent out of the field of view. Details of the feed nozzle are blurred because of glass fibers adhering to tiıe nozzle that are waving in the off-gas flow during the timed exposure required to take the picture.

Figures 10 through 14 are a sequence of photos showing the burnoff of the cold cap when the feed was stopped at 23:30 on June 8, 1985. Figure 10 was taken two minutes after the feed was turned off. The remaining photos were taken at ten-minute intervals thereafter.

Note that in all eight photographs there is a glow between the south electrode and the south wall of the melter. It appears that the hot glass has gotten between the electrode and the wall, and thermal radiation is emanating from the gap between the two melter components. Indeed, when the PSCM was disassembled following PSCM-22, a gap of at least $5 \mathrm{~cm}$ was found between the electrode and the wall (Koegler 1987). Thus, the camera can be used to inspect the physical condition of the melter. 
Testing of the IR camera during PSCM-22 was plagued with a number of problems. The camera was not installed until the final week of the run and was used for only $96 \mathrm{~h}$. Before the run started, the nose piece that protects the lenses and mirrors which extend into the melter plenum was found to have corroded to the extent that cooling to the lenses was lost. This corrosion necessitated refabricating several parts of the camera housing. Installation was further delayed by a short circuit in the electronics of the camera itself. A buildup of glass and corrosion products in the melter-lid nozzle sleeve, through which the camera must slide to look into the melter, had to be removed before the camera could finally be installed. Picture quality was not as good as with previous melter runs. This loss of quality was probably a result of 1) changes in critical distances within the optical path caused by the refabrication of the camera housing, and 2) reinstallation of the surface mirrors backwards so that the image was reflecting off multiple interfaces.

The RLFCM camera has not been used to date. The dose rates generated by the high cesium and strontium levels in the glasses being produced for the Federal Republic of Germany (FRG) are of the order of $5 \times 10^{5} \mathrm{R} / \mathrm{h}$. This is approximately 50 times higher than the dose rates expected for the wastes at WVDP. At the higher dose rates of the FRG glasses, the video tube would have an expected lifetime of less than $1000 \mathrm{~h}$.

While both the visible and the IR-spectrum configurations appear to give good pictures of the melter interior when there is little or no cold cap, neither camera configuration provides much detail when the cold cap is large (Figure 10 for example). This is a result of the sensitive range of the video tube in the camera. Referring back to Figure 2, the video tube is sensitive to thermal radiation between $400 \mathrm{~nm}$ and $950 \mathrm{~nm}$. As the blackbody radiation curves show, temperatures must exceed $600^{\circ} \mathrm{C}$ before the thermal radiation can be seen by the video tube. As Figure 15 shows, plenum temperatures can drop below $600^{\circ} \mathrm{C}$ with as little as 30 to $40 \%$ cold cap coverage and below $500^{\circ} \mathrm{C}$ with $100 \%$ cold cap coverage. With 30 to $40 \%$ coverage, there is still sufficient molten glass exposed to illuminate the melter. However, at $100 \%$ coverage, there is no illumination other than that due to venting; the melter will appear black even in the IR configuration. The lack of illumination is itself an 


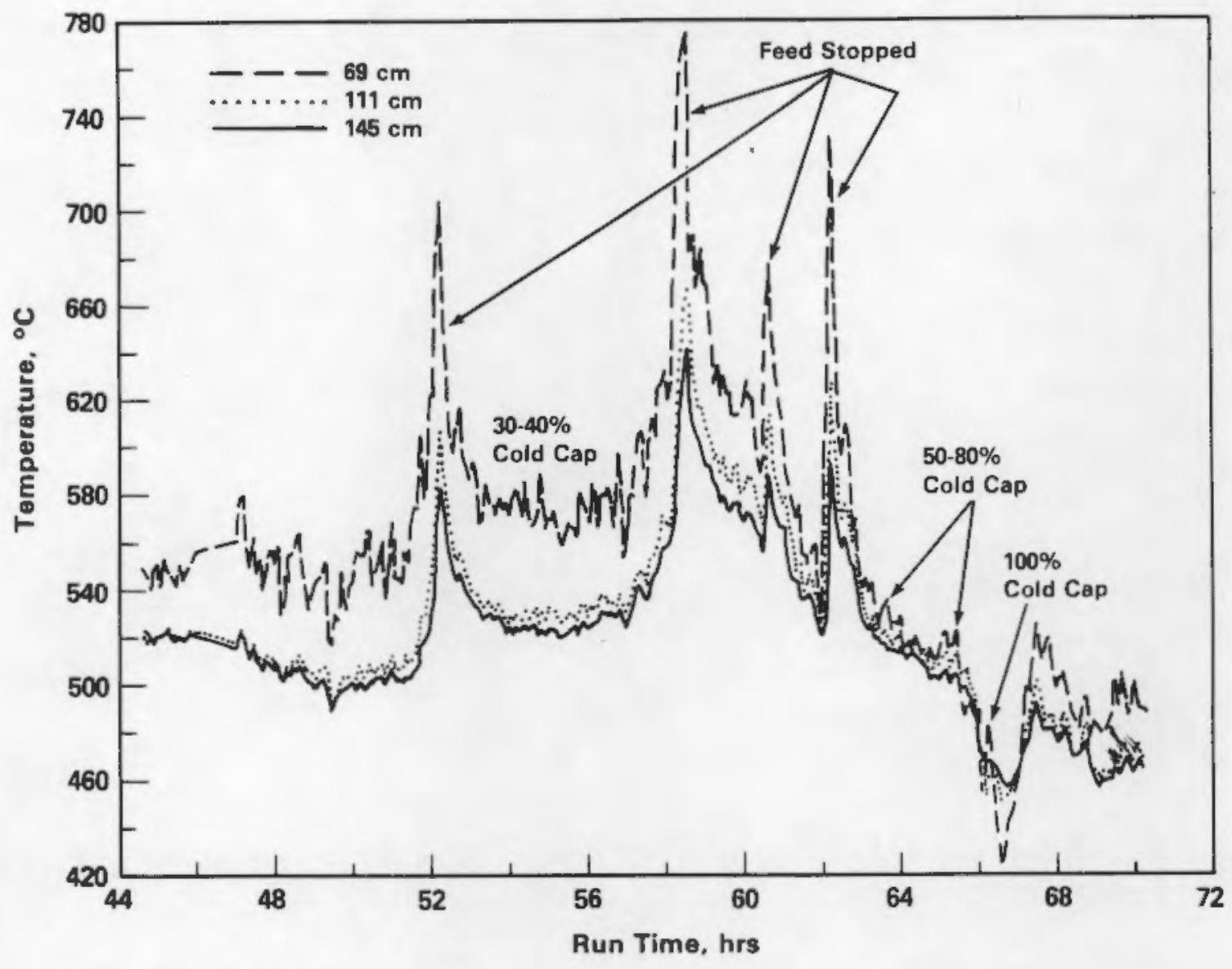

FIGURE 15. Plenum Temperatures for Run PSCM-16

indication that overfeeding is being approached. The lack of detail is more of a problem when trying to develop models of the cold cap, when, for example, it is important to distinguish between regions of boiling and dried feed.

Thermal imaging systems are available that are sensitive to the 3-6 $\mu \mathrm{m}$ and 8-12 $\mu \mathrm{m}$ regions. However, it is very difficult if not impossible to design a wide-angle periscope to relay the image of the melt surface to these systems. Furthermore, liquid nitrogen is required as a coolant in some models, and the scan rates and resolution are poor in others. 


\section{NEW PNL CAMERA DESIGN}

Operating experiences with the HBCM/PSCM camera led to some design improvements to be implemented in a new PNL camera. First, although the cooling air flow pattern provided sufficient cooling of the camera, we still wanted to move as many of the optical components as possible away from the hot region of the camera that is directly exposed to the melter. Second, we wanted a more upright camera such that could be rotated without interfering with other equipment on the melter. Third, we wanted a camera that could be easily and rapidly repaired.

Critical to achieving these design goals was a modification to the PSCM 1id. Previously, all process nozzles were oriented vertically or horizontally. During the rebuilding of the PSCM, a special nozzle with an angle 30 degrees from vertical was placed in the northwest corner of the melter lid (Koegler 1987). We recognize that vertical nozzles are preferred in the hot cells, but it is possible to design devices that could be used in the hot cells with manipulators to install the camera in an angled nozzle. The camera could also be placed vertically on a flange near the center of the melter.

In all of the previous camera designs the optical axis is vertical as it penetrates the melter and is then deflected $30 \mathrm{~d}$,rees from vertical in order to view as much of the glass surface as possible from one corner of the melter. There is no need for this offset in the new PNL design because of the 30-degree nozzle; therefore, the design could be simplified (see Figure 16 and Appendix E). Two mirrors and a complex offset mounting structure are eliminated from the nose of the camera. The outer casing of the camera that extends through the refractory is made of Inconel $690^{(a)}$ to resist corrosion. The nose of the camera is a thicker and simpler structure that should be less subject to corrosion. The steam jet has been retained to keep the aperture clear of obstructions. Servicing, if required, will be easier because the optical system is more readily removed from the outer enclosure.

(a) Inconel is a trademark of the Huntington Alloys Corporation, Huntington, West Virginia. 


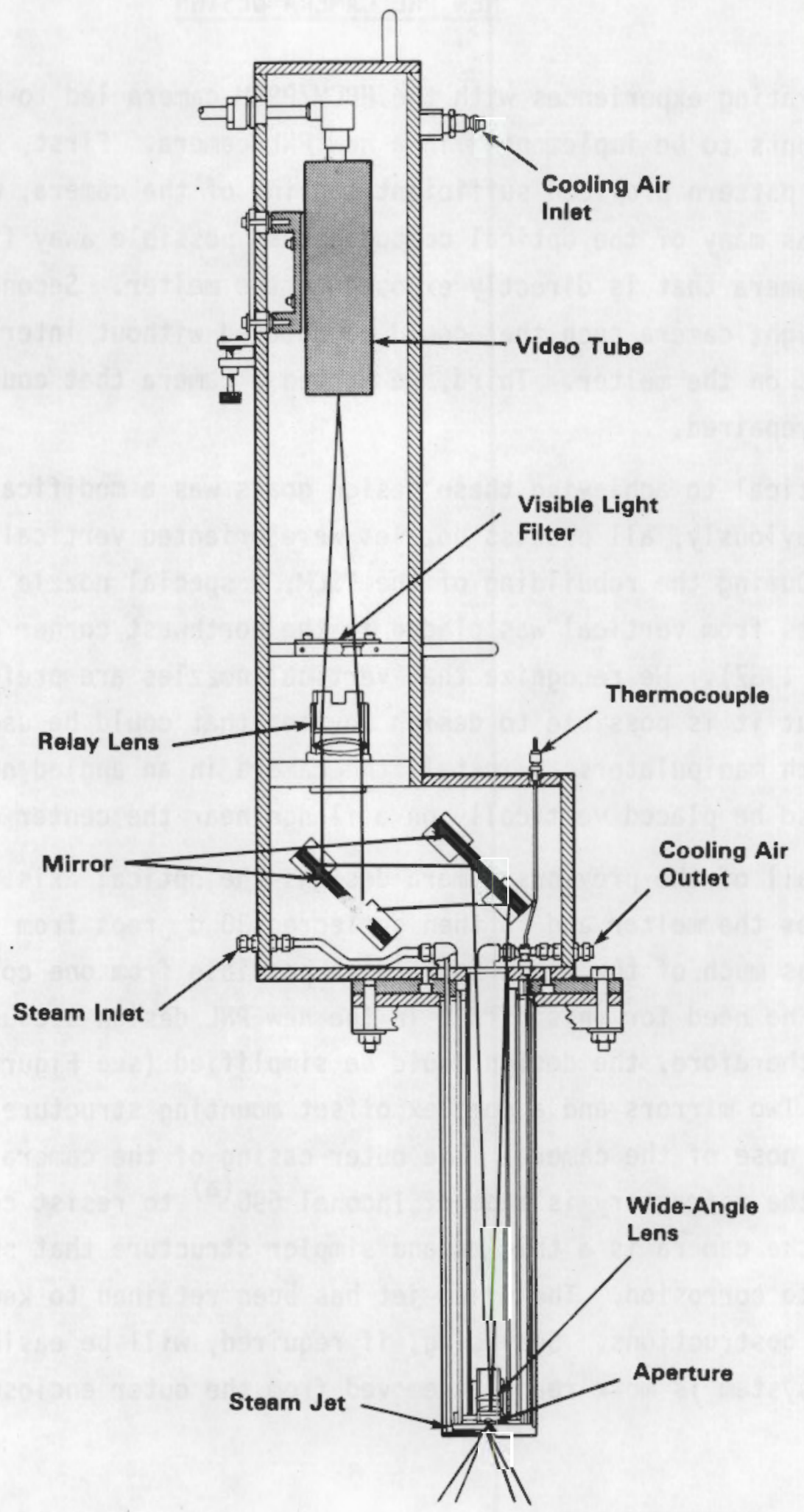

FIGURE 16. New PNL Camera Design 
The cooling-air flow patterns are retained in the new camera design. The main cooling air flows past the video tube, through the camera body, past the wide-angle lens, and back out into the atmosphere. A second, smaller stream of air flows past the face of the wide-angle lens, through a $0.152-\mathrm{cm}$-diameter aperture into the melter plenum. The noses of the HBCM/PSCM and RLFCM cameras must extend into the melter plenum to view the melter surface. The new PNL camera is designed to be recessed into the refractory, which should also help keep the camera cool.

The optical requirements for the new PNL periscope camera are quite similar to those for the RLFCM camera. Although the viewing distance in the PNL canera is $91 \mathrm{~cm}$ rather than $46 \mathrm{~cm}$, the optical design for both cameras consists of a wide-angle objective lens, a relay lens, a filter and the video system. Two mirrors are used to offset the optical axis outside the melter in order to remove the video camera from the direct radiation beam.

The objective lens assembly consists of three elements. The first element is the primary image former; the other two elements direct the light into the relay lens. The first or front element is also the smallest element and the one most directly exposed to the heat, radiation, and spatter of the melt. It is fabricated of synthetic fused silica, which resists damage resulting from thermal shock ....d resists darkening resulting from radiation. Lenses 2 and 3 are made of Schott BK-7-6-18 radiation stabilized glass. The second and third lens elements in the set are mounted together with the front lens in a stainless steel housing, which is cooled by air that flows down the innermost tube and back up through a concentric tube of larger diameter.

Light from the image formed by the objective lens assembly is transmitted up the innermost tube to a pair of mirrors outside of the melter. Both mirrors can be adjusted to align the optical beam with the relay lens and video camera.

A relay lens reforms an image on the sensitive surface of the camera tube. The relay lens consists of two elements, one made of Schott BK-7-G-18 and the other made of Schott F-2-6-12. Both lens materials are stabilized against darkening that results from nuclear radiation. This combination of 
glasses is used to achromatize the lens system for three wavelengths in the visible spectrum. The objective and relay lenses were designed as one group to obtain optinum performance.

An optical filter is mounted between the relay lens and the video camera to limit the spectrum to either the visible or the near-IR portion of the spectrum. Typically, the visible transmitting filter cuts off at $700 \mathrm{~nm}$. When the 2 f filter is used, this effective pass band is limited to the region between $700 \mathrm{~nm}$ and $900 \mathrm{~nm}$. This is a relatively narrow band, and no effort was made to optimize or achromatize the optics for this band. 


\section{REFERENCES}

Barnes, S. M., J. H. Westsik, Jr., and B. M. Wise. 1985. "Instrumentation Concepts for Nuclear Waste Glass Melters." Waste Management 85. University of Arizona, Tucson, AZ.

Burkholder, H. C., and J. H. Jarrett, Compilers. 1986. Nuclear Waste Treatment Program Annual Report for FY-1985. PNL-5787, Pacific Northwest Laboratory, Richland, WA.

Burkholder, H. C., J. H. Jarrett, and J. E. Minor, Compilers. 1985. LFCM Vitification Technology Quarterly Progress Report January - March, $1 \overline{985}$. PNL-5470-2, Pacific Northwest Laboratory, Richland, WA.

Burkholder, H. C., J. H. Jarrett, and J. E. Minor, Compilers, 1986 . LFCM Vitrification Technology Quarterly Progress Report July - September, 1986. PNL-5470-4, Pacific Northwest Laboratory, Richland, WA.

Heckendorn, F. M., II. 1983. "DWPF Process Control." Waste Management 83. University of Arizona, Tucson, AZ.

Heckendorn, F. M., II. 1986. Remote viewing of Melter Interior, Defense Waste Processing Facility. DP-MS-86-74, E. I. duPont de Nemours \& Co., Savannah River Plant, Aiken, SC.

Koegler, S. S. 1987. Pilot-Scale Ceramic Melter 1985-1986 Rebuild. PNL-6259, Pacific Northwest Laboratory, Richland, WA.

Siegel, R., and J. R. Howell. 1981. Thermal Radiation Heat Transfer Hemisphere Publishing Corporation, Washington DC.

Siemens, D. H., et al. 1985. High-Level Radioactive Waste Vitrification Process Equipment Component Testing. PNL-5394, Pacific Northwest Laboratory, Richland, WA.

Westsik, J. H., et a1. 1985. Instrumentation for Remote Control of LiquidFed Ceramic Melters, PNL-5635, Pacific Northwest Laboratory, Richland, WA. 



\section{APPENDIX A}

DETAILED DRAWINGS OF THE HBCM/PSCM CAMERA 


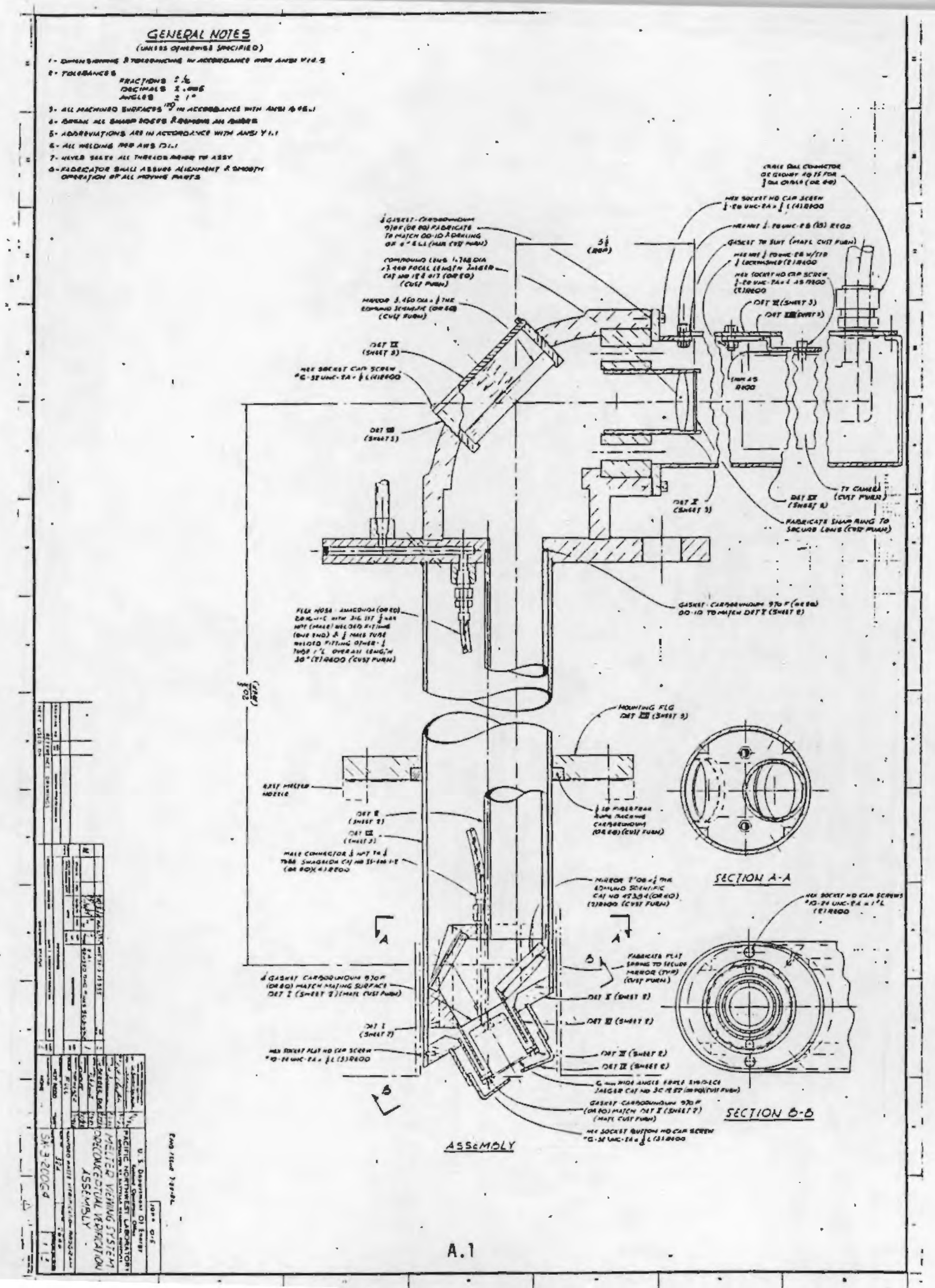




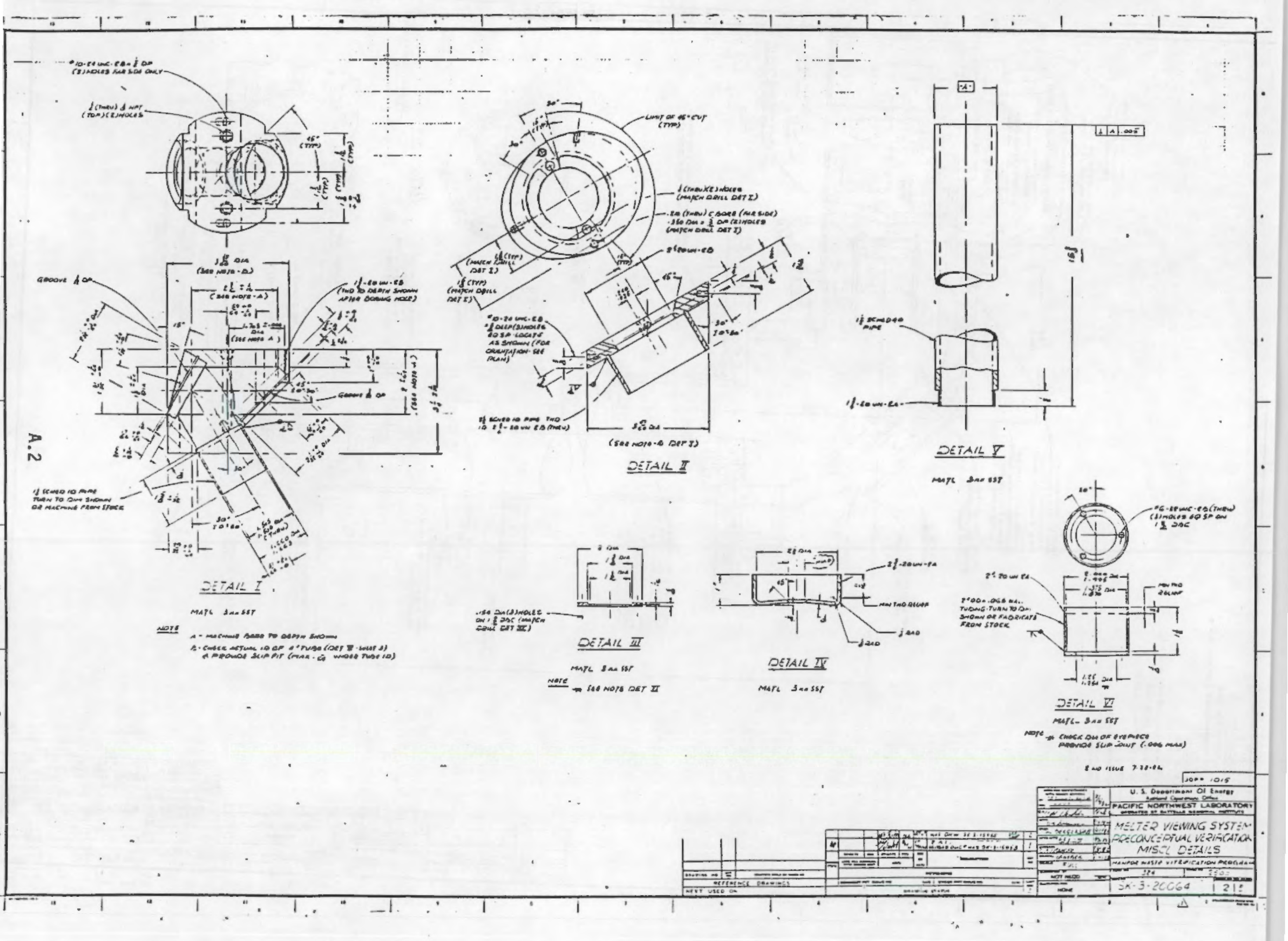



APPENDIX B

DETAILED DRAWINGS OF THE RLFCM CAMERA 


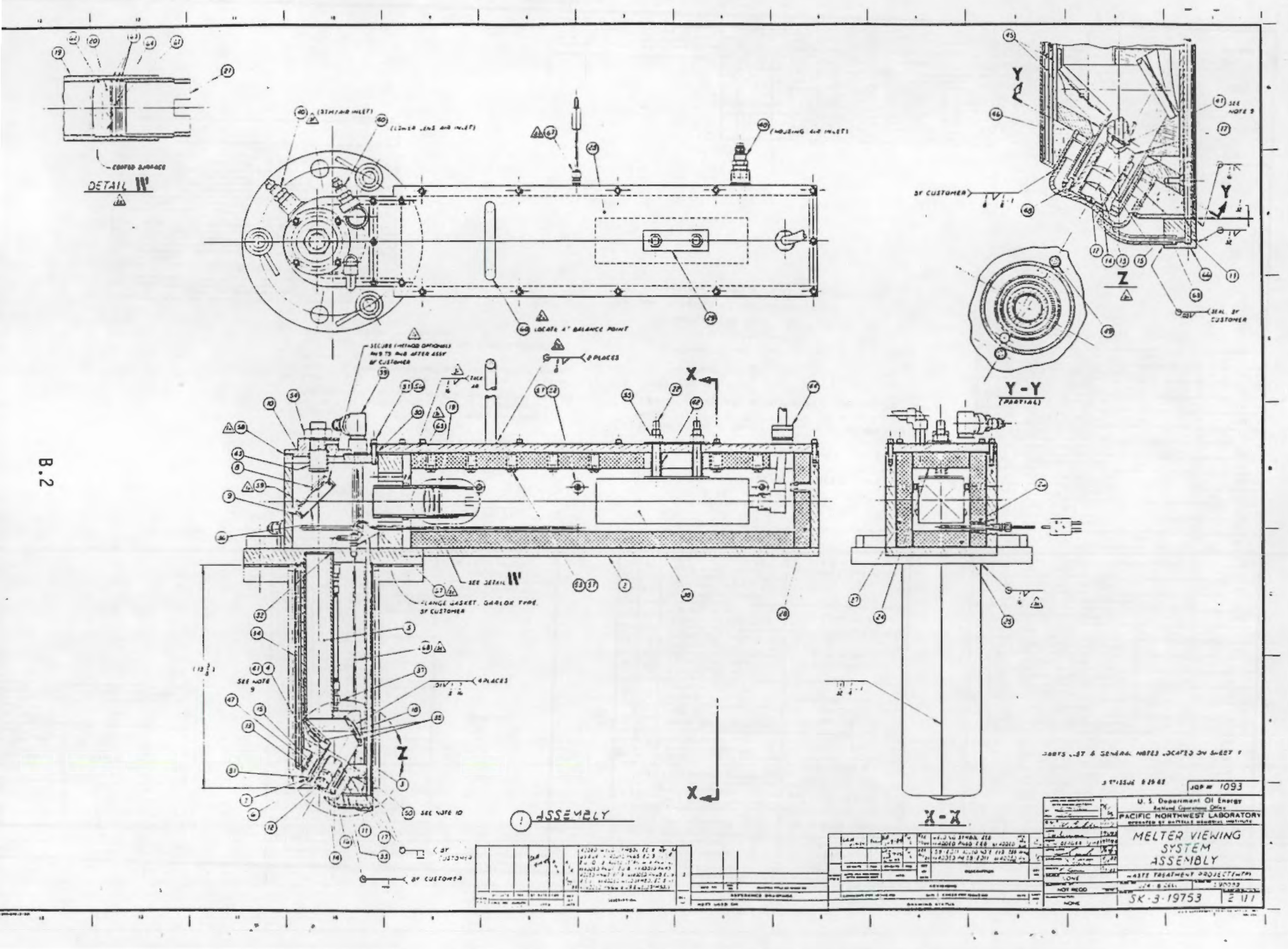




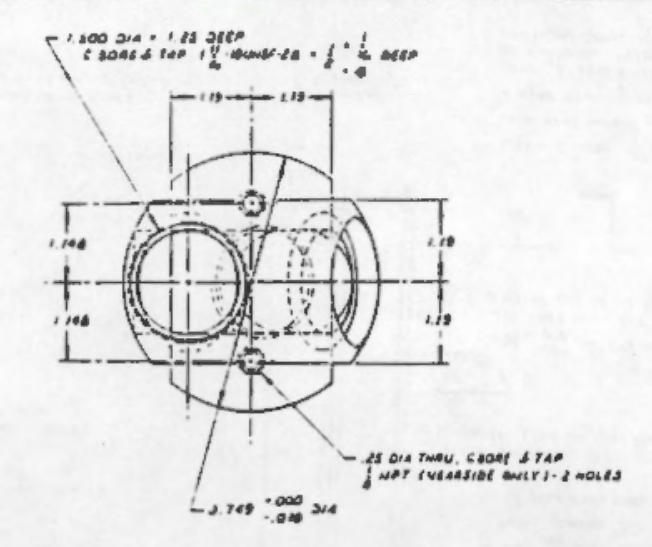

$\stackrel{\infty}{\circ}$
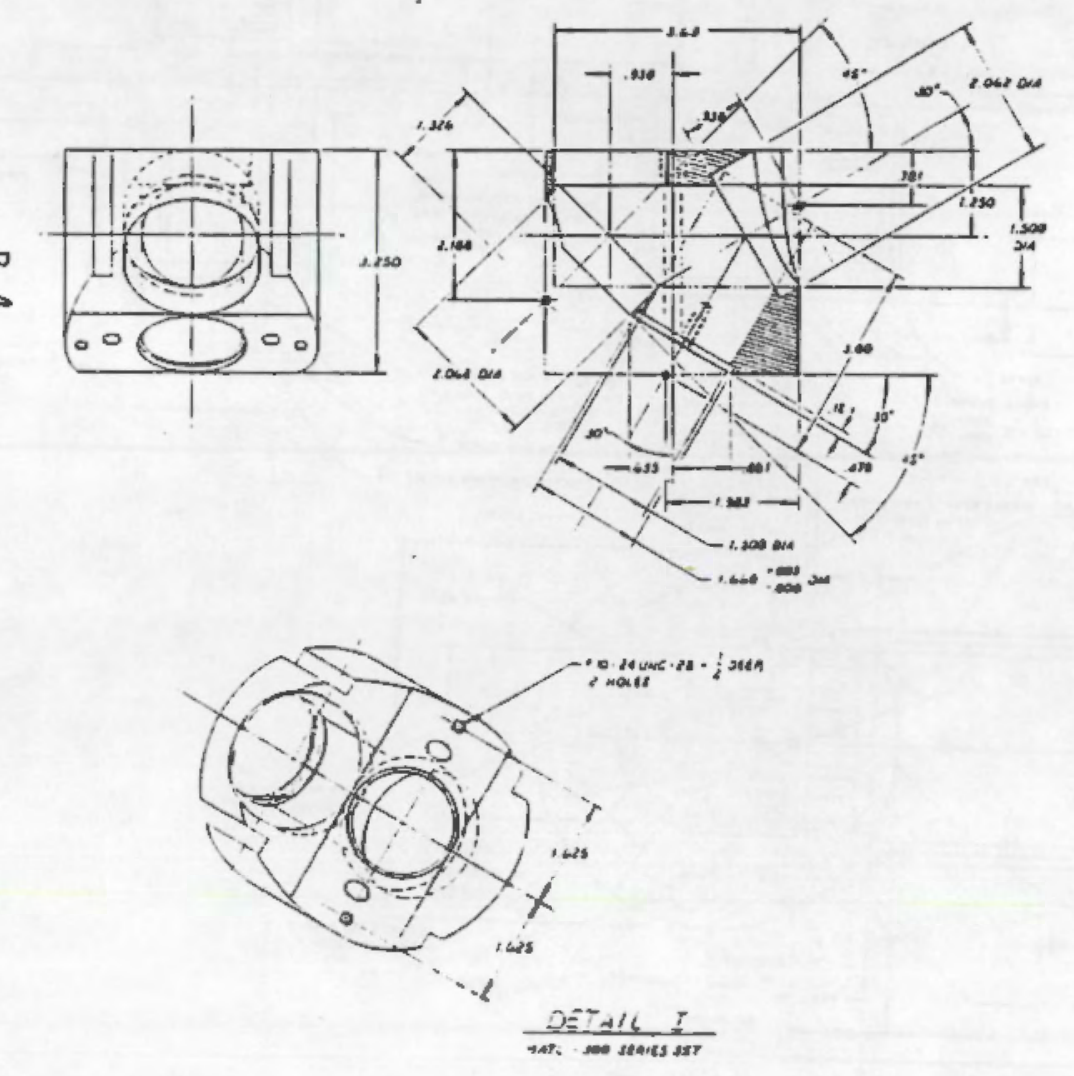
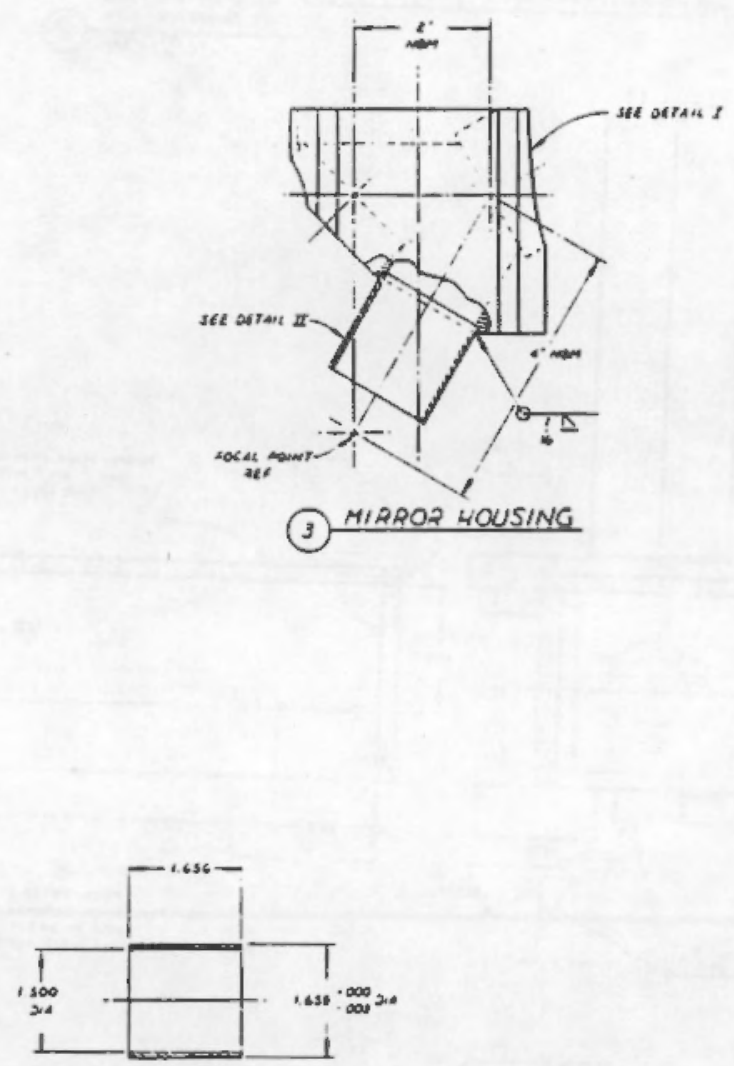

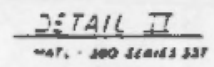

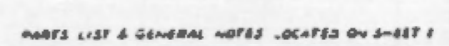

arsue expes 1093

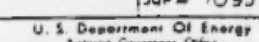

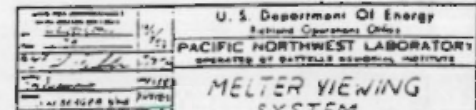
$\Rightarrow, T$ DETAILS $=2.2-10$ Detalls $H+1-1=1$

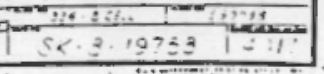



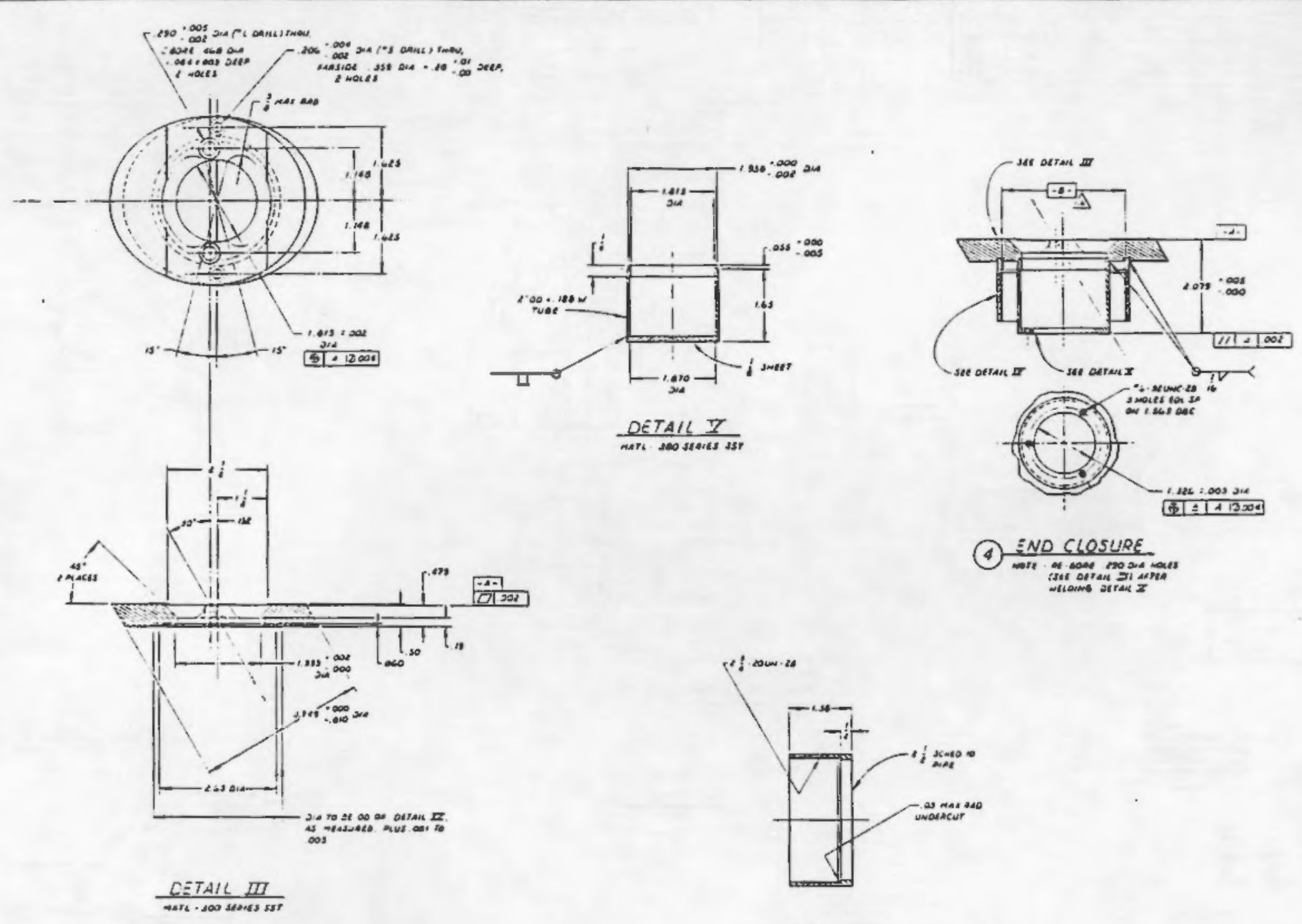

(4) END CLOSURE

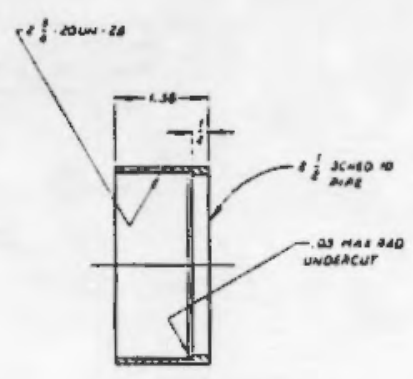

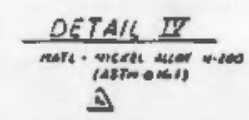

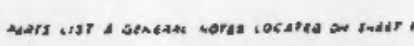

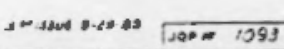
$=7$ Fis.

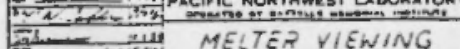

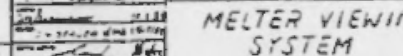
SYSTEM 


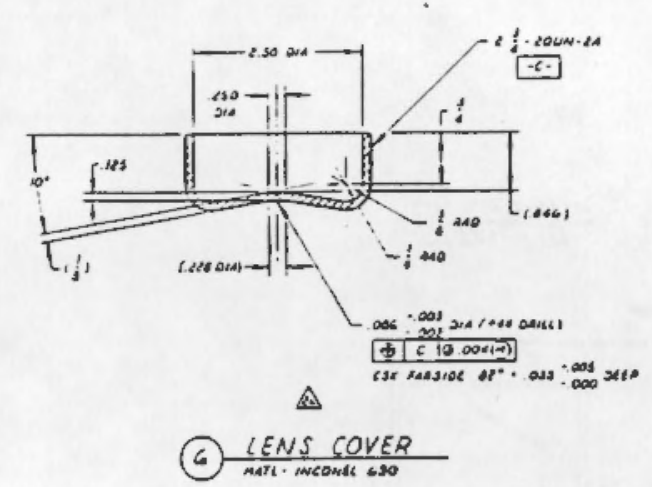

, on
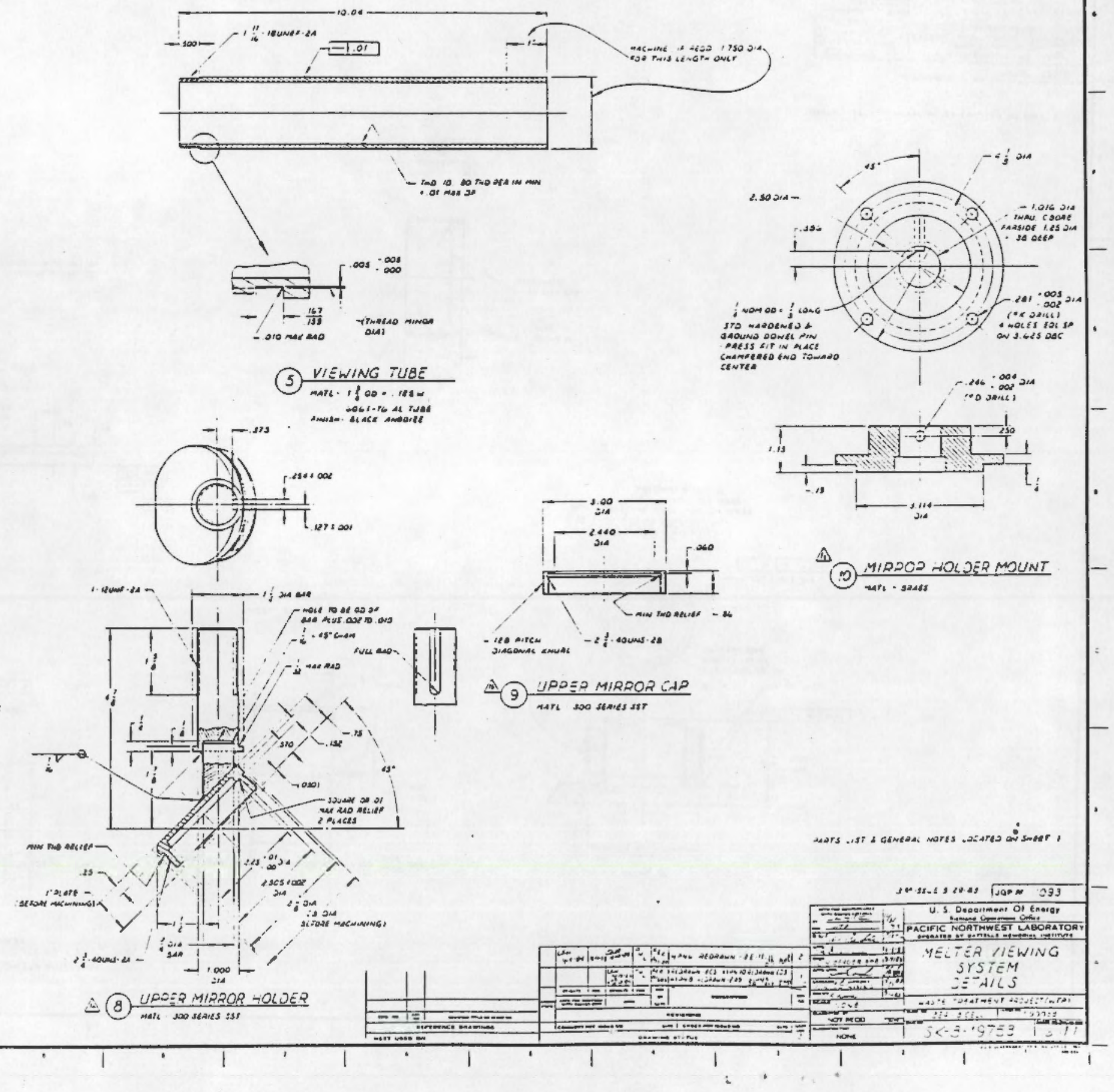


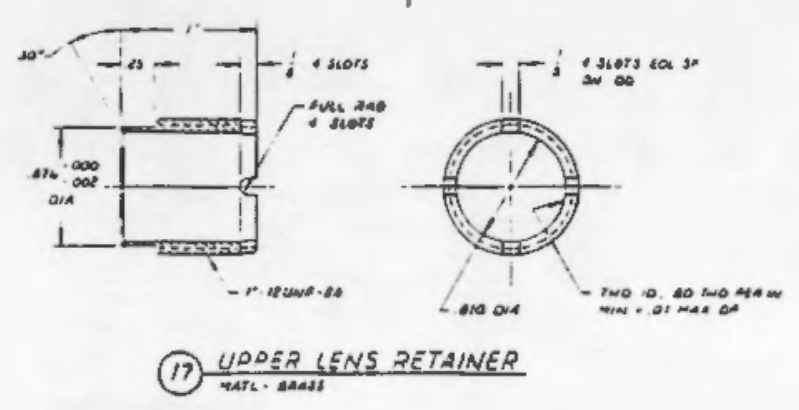

$\stackrel{0}{0}$

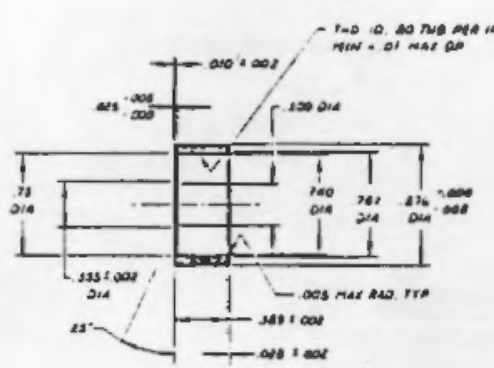

(13) LOWER IEVS RETAINER

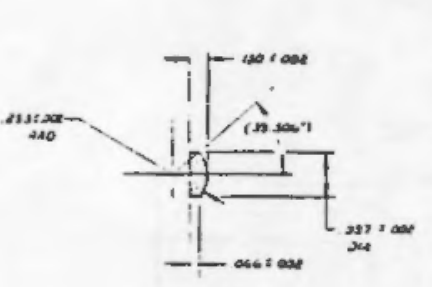

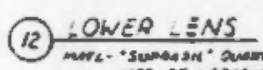

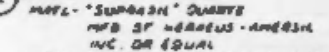

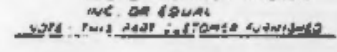

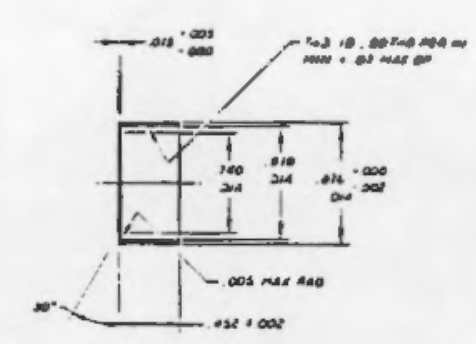

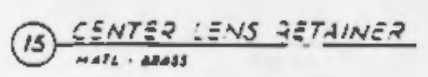

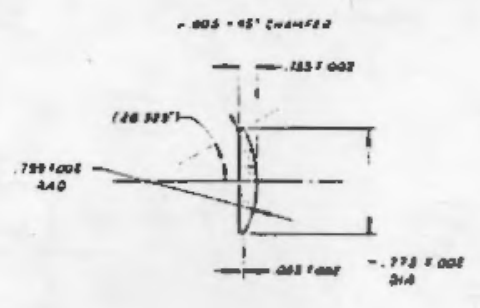

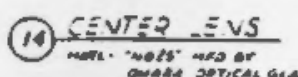

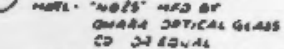

vorf

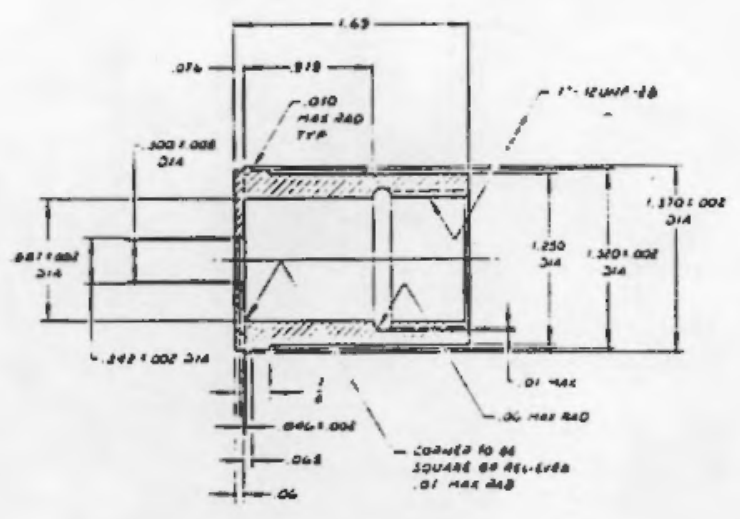

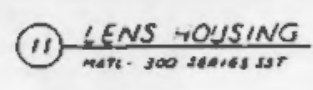

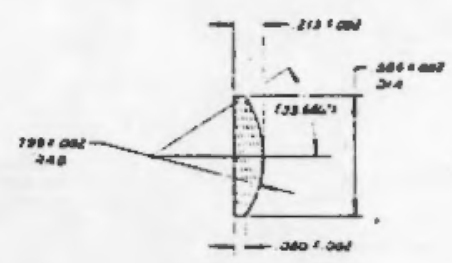

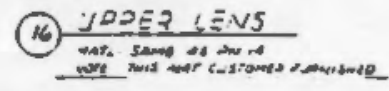

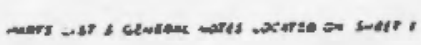

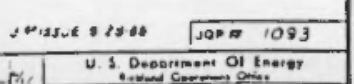

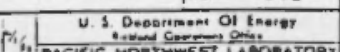

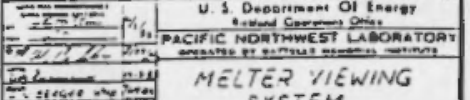
SYSTEM
DETAILS

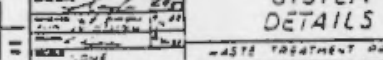

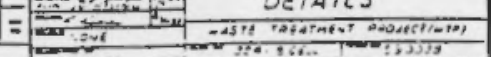

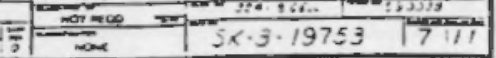


$\infty$

$\infty$

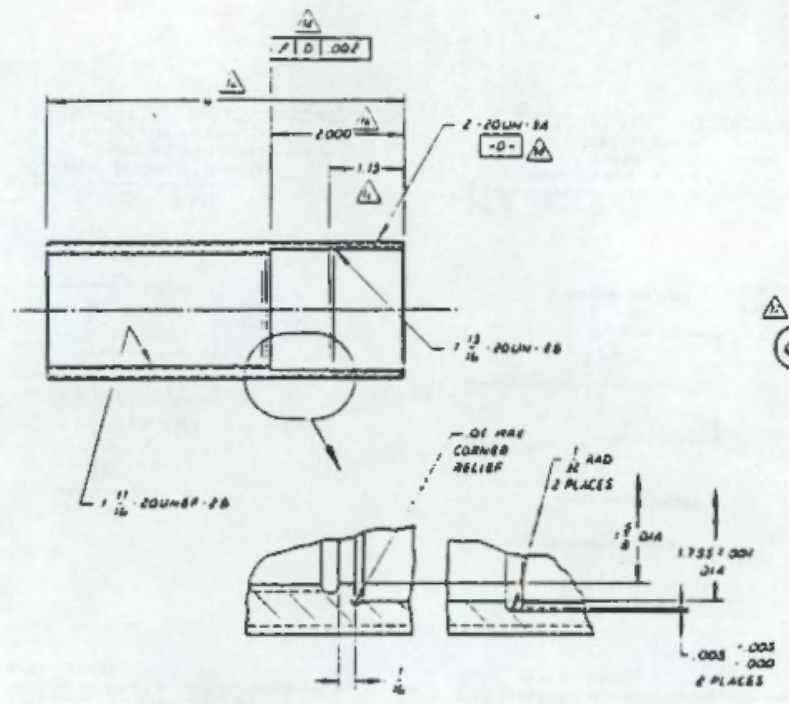

(19) J00E2 : ENS 40I0E?

तो
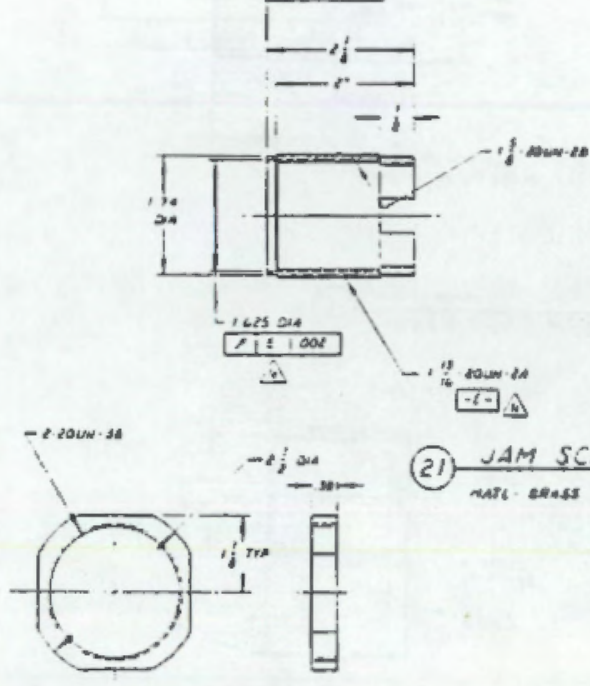

(21) $\mathrm{JAM} \mathrm{SCREW}$

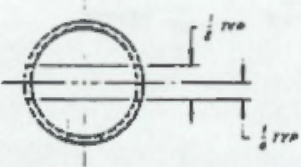

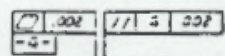

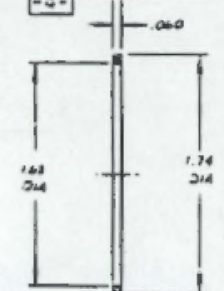

(64) ARERTURE DISC

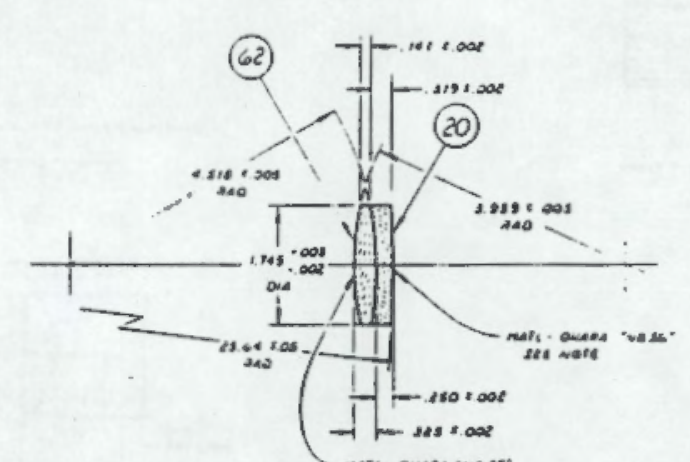

norti. ameas insess

$\Delta$

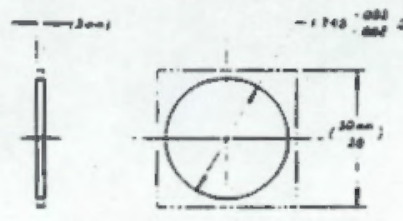

TOP :ENSES

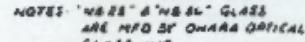

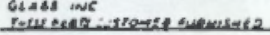

A(63) 5 SAC58

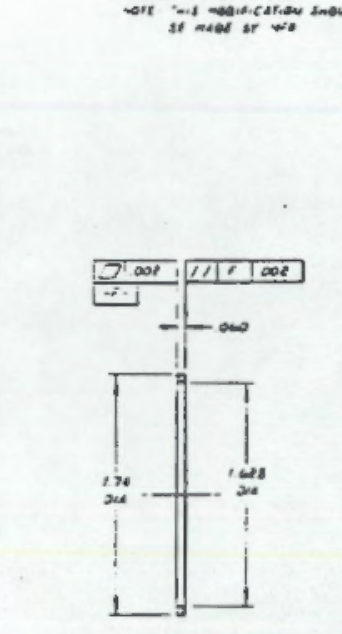

(6) $\rightarrow$ TOT MIRDOR

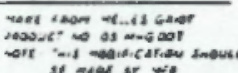

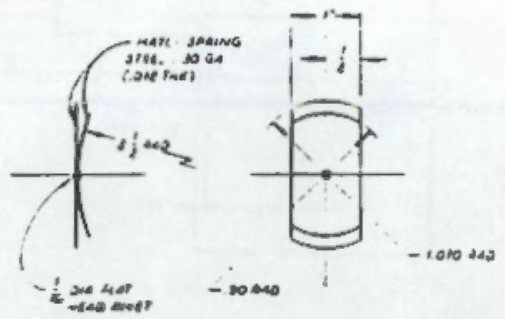

(10) MIRROR RETAINING SPRING

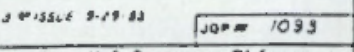

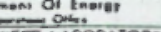
mEs TER VIEWING SYSTEM

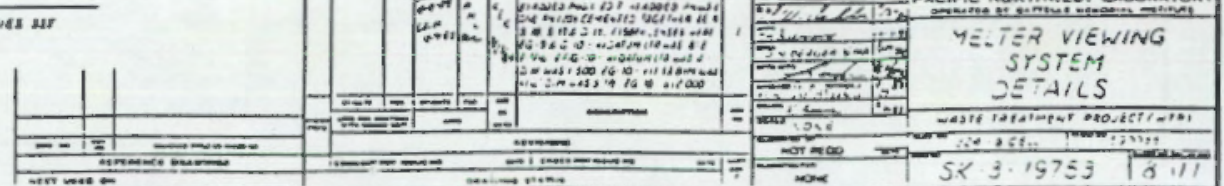




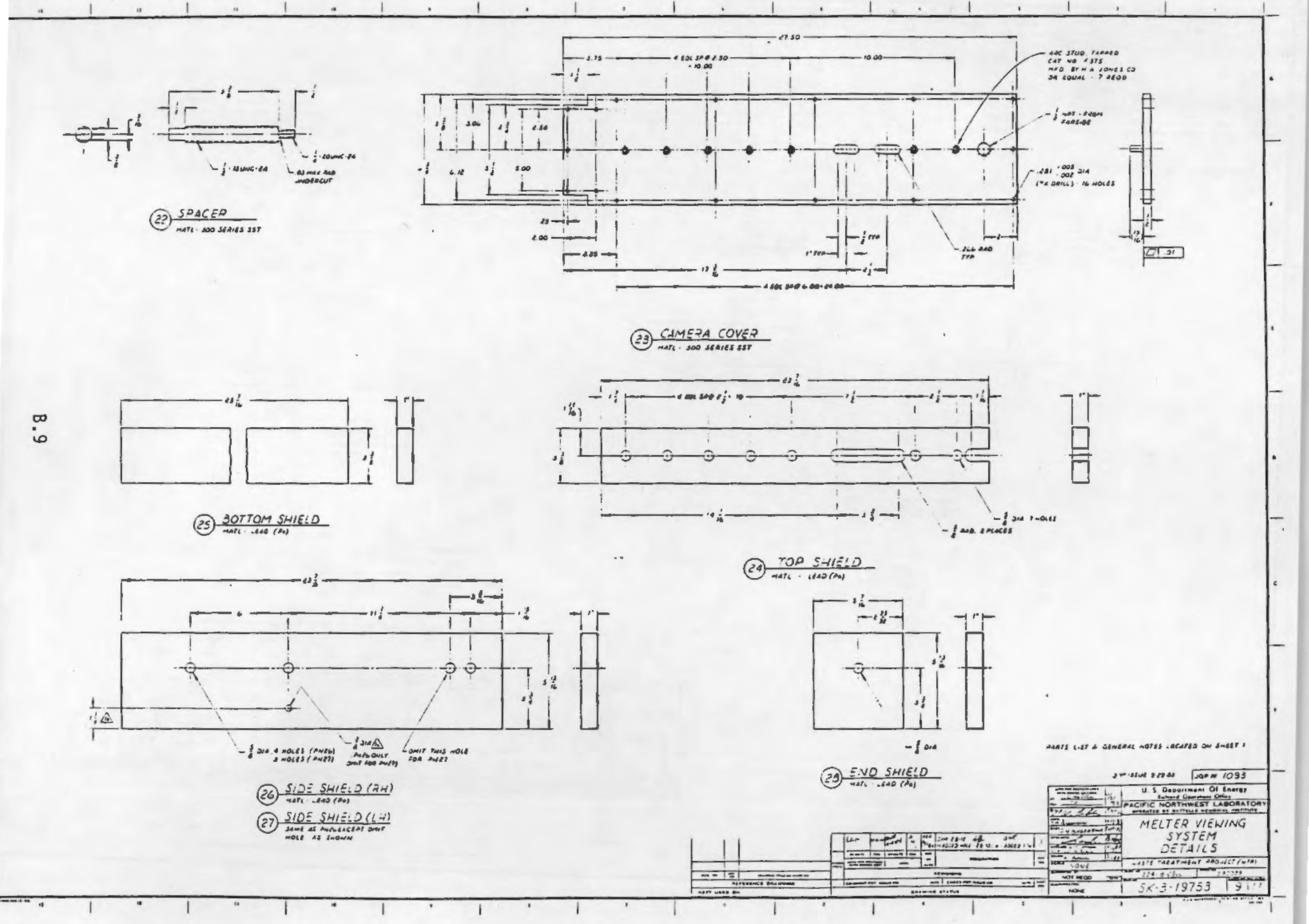




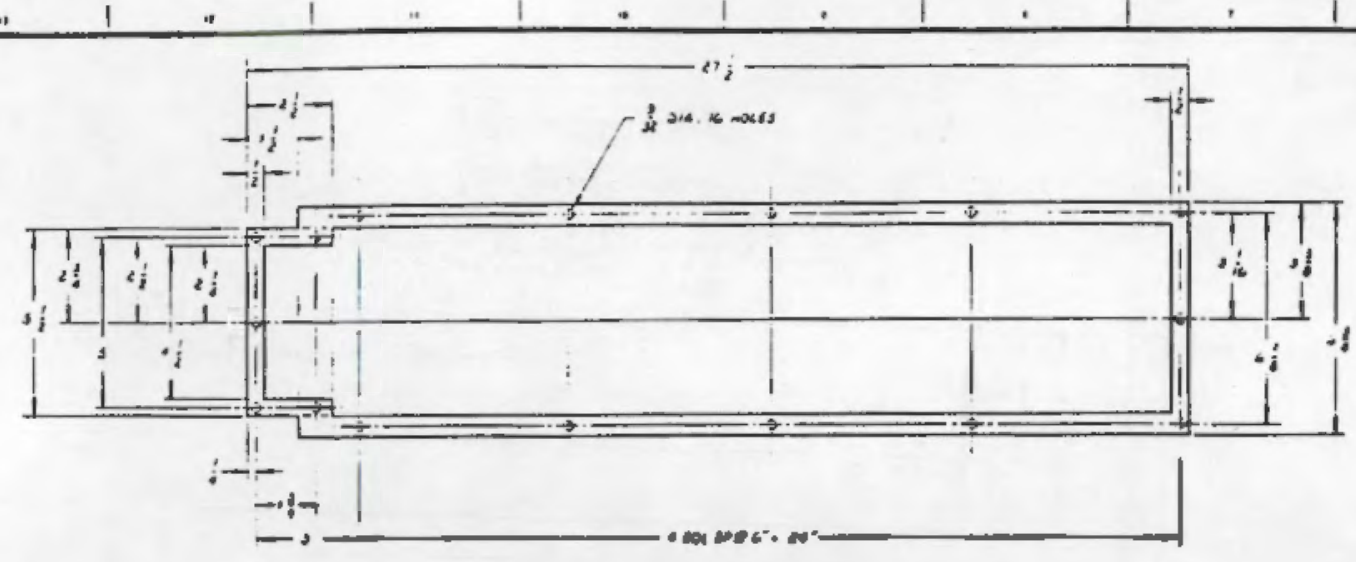

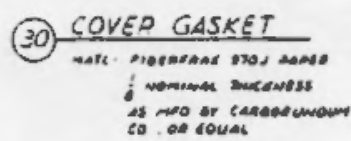

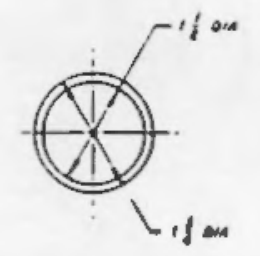

(22) TUAE GASKET

$\stackrel{0}{0}$

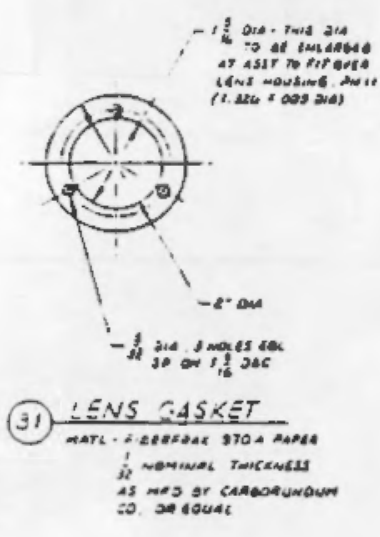

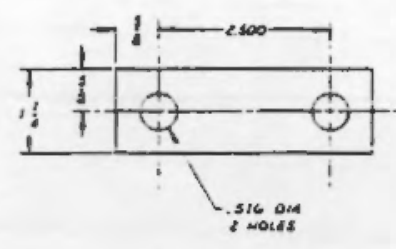

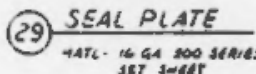

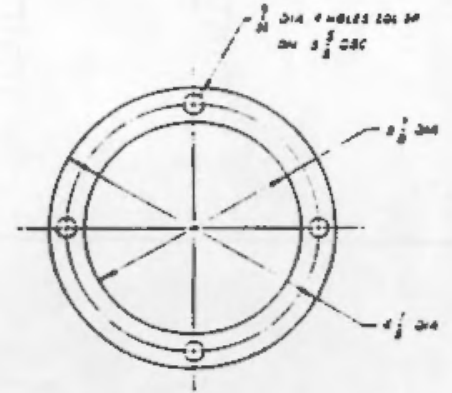

$\triangle$ (58) MOUNT GASKET

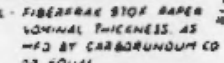

Sers ust s Gevereat wares cosaste on wert

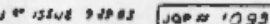
U. D. Deoeriment of Easer

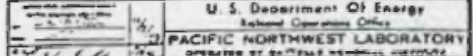

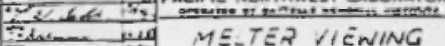
Then ME TEN VIEWING DETAILS 

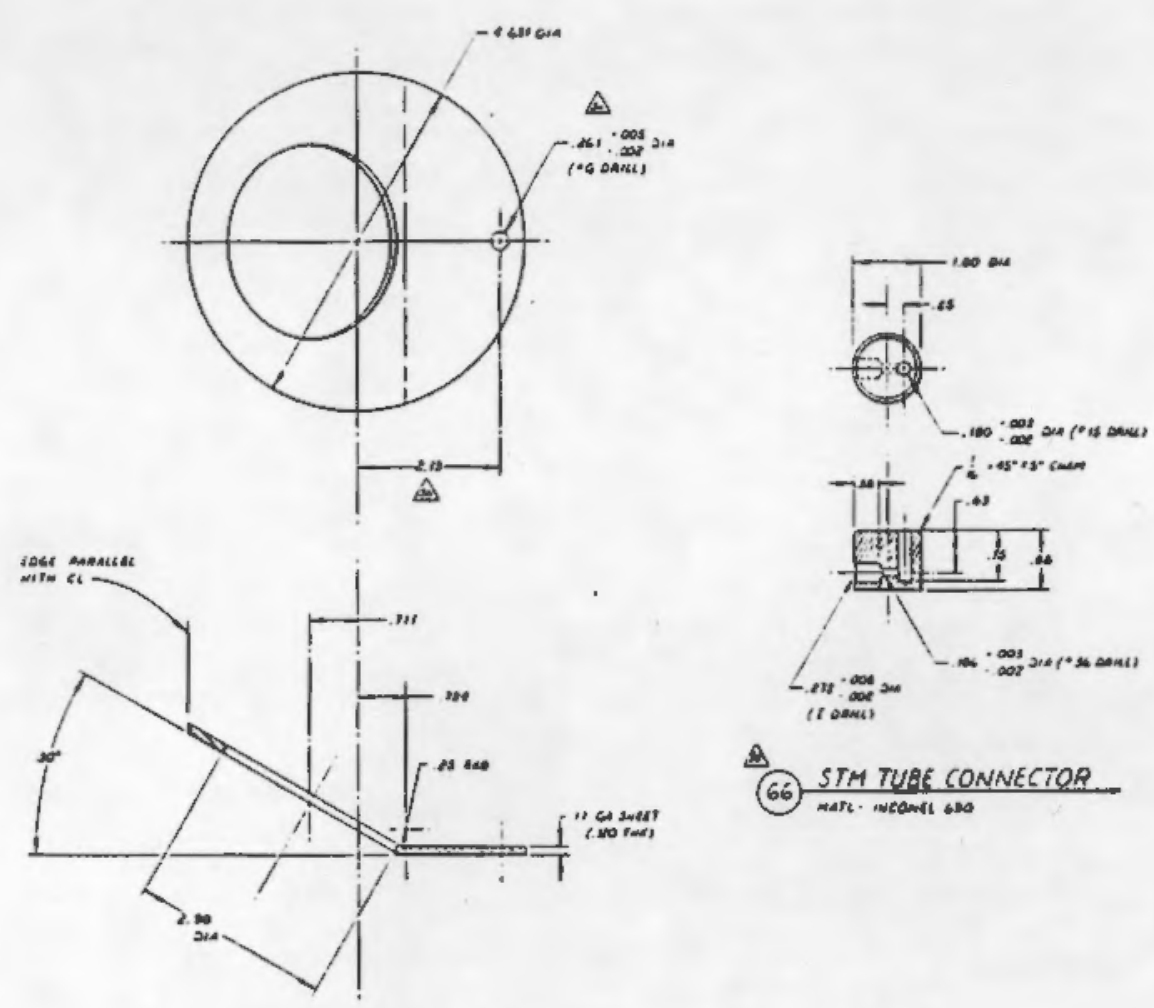

品
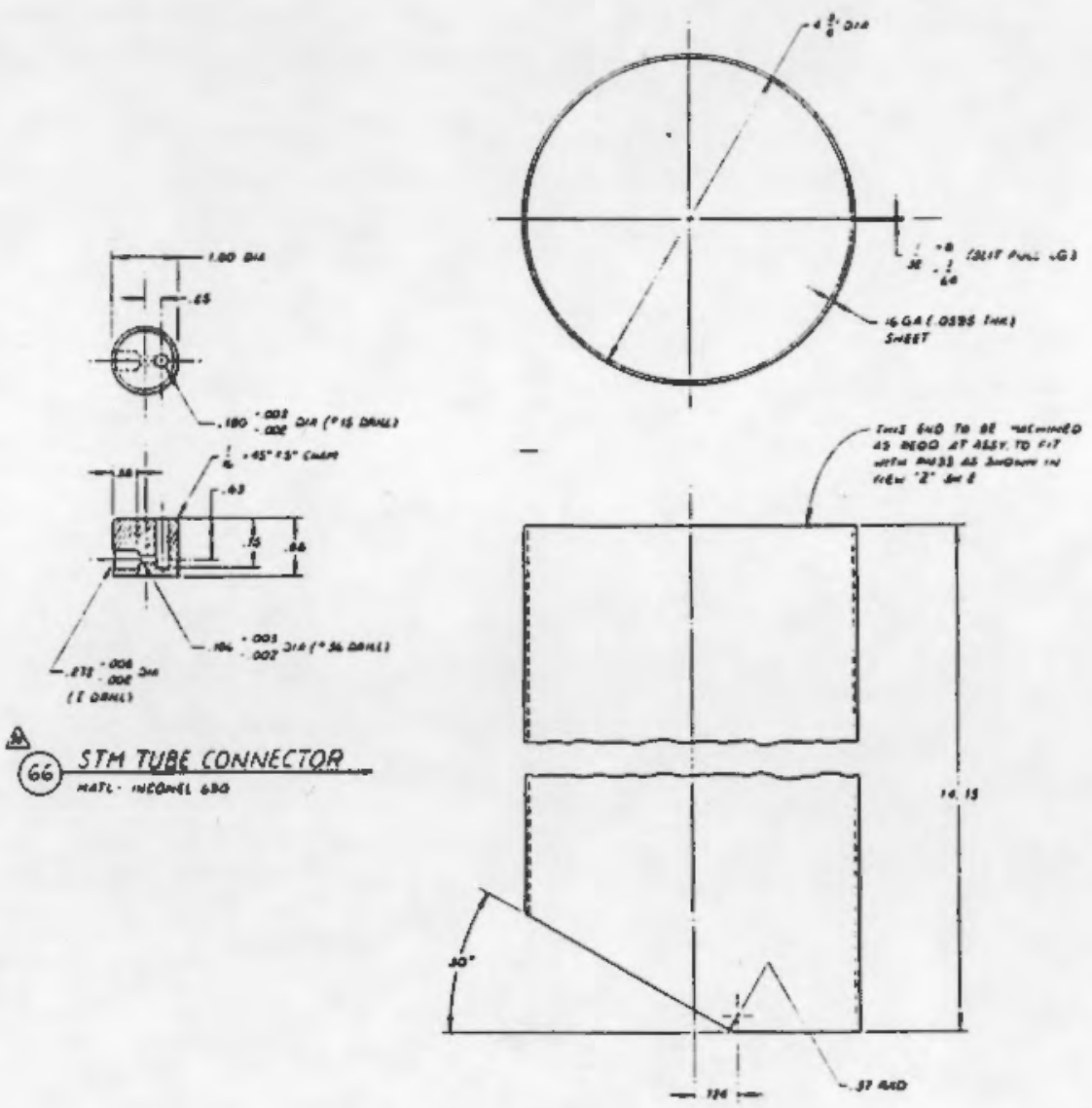

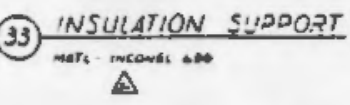

66) STM TUBE CONNECTOR

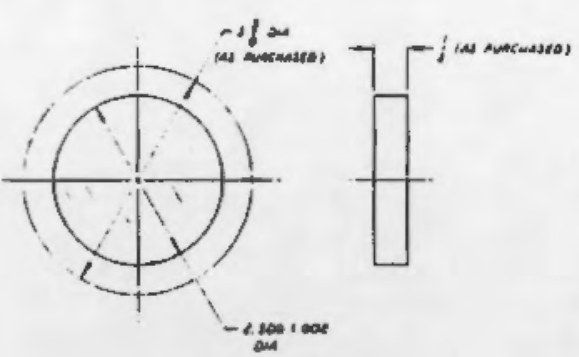

(194) INSULATION YASKKET
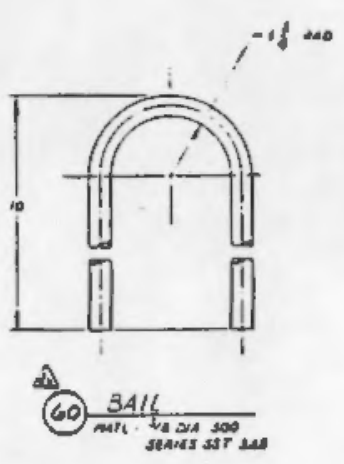

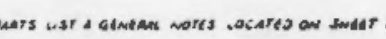

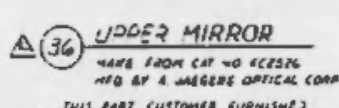

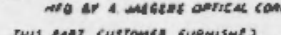

गaen 1093

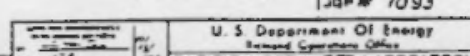

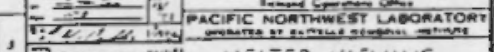

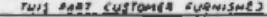




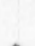


APPENDIX C

CONCEPTUAL DESIGN FOR THE WVDP CAMERA 


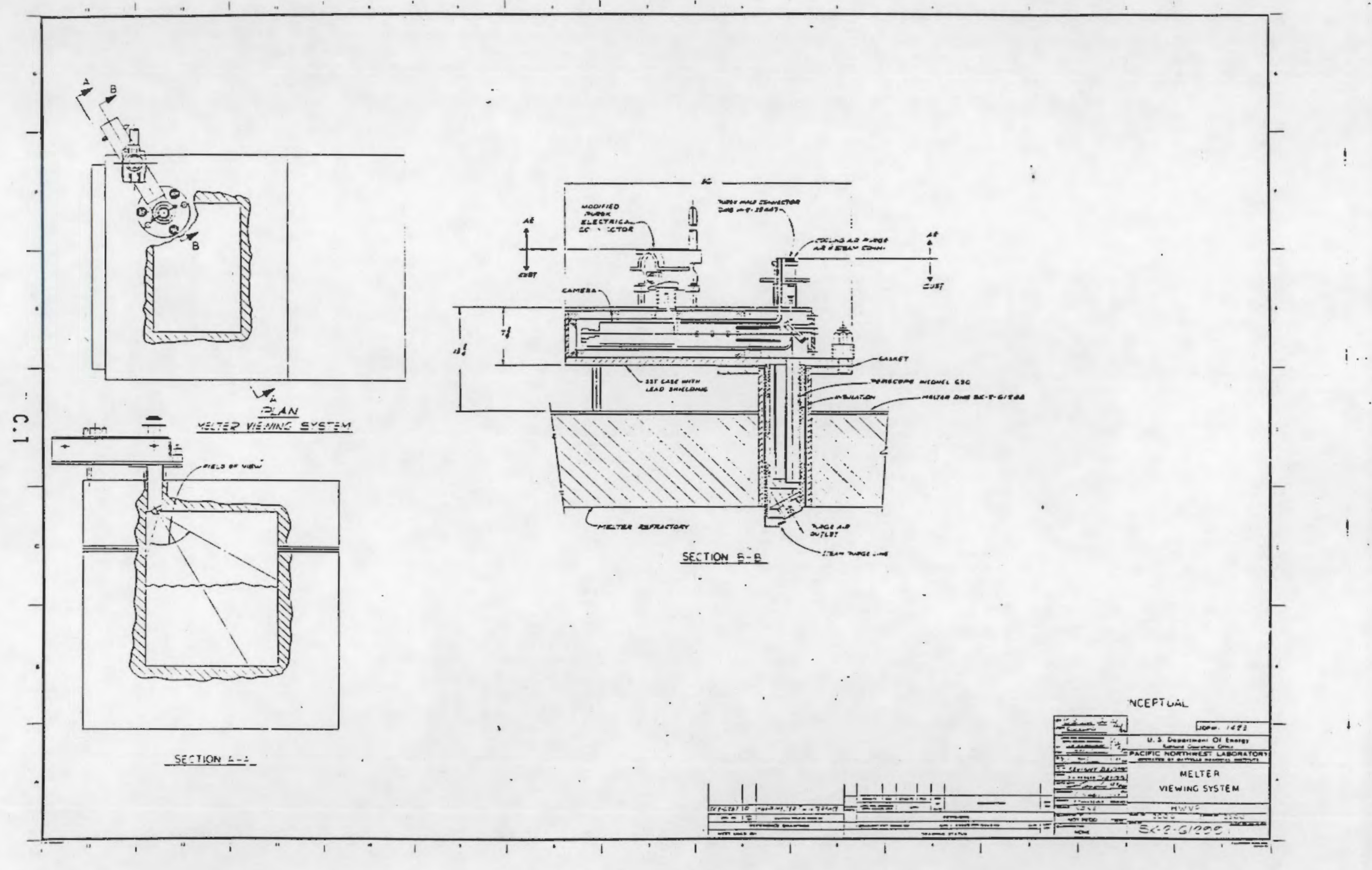




\section{APPENDIX 0}

CONCEPTUAL DESIGN FOR THE HWVP CAMERA 


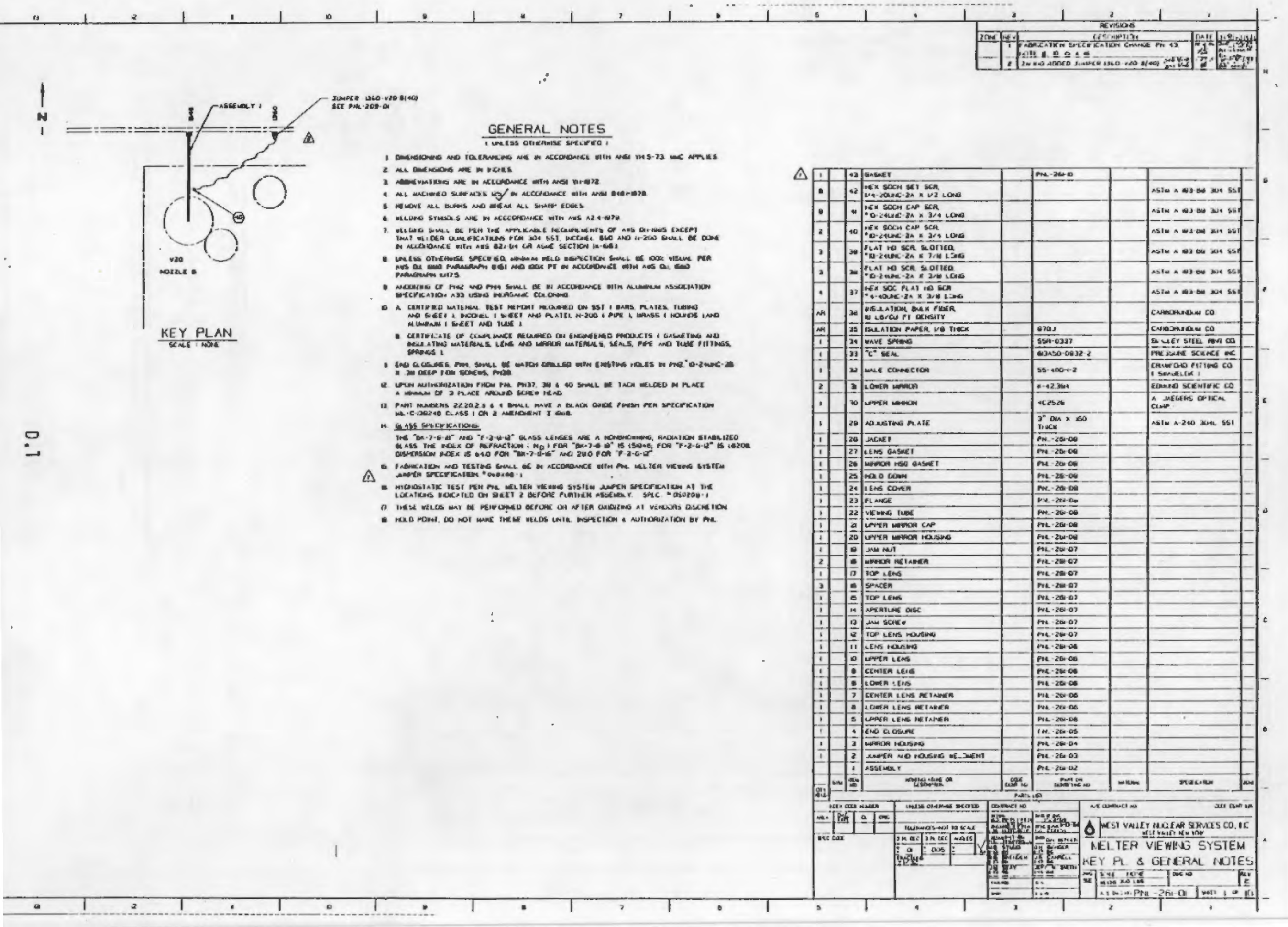




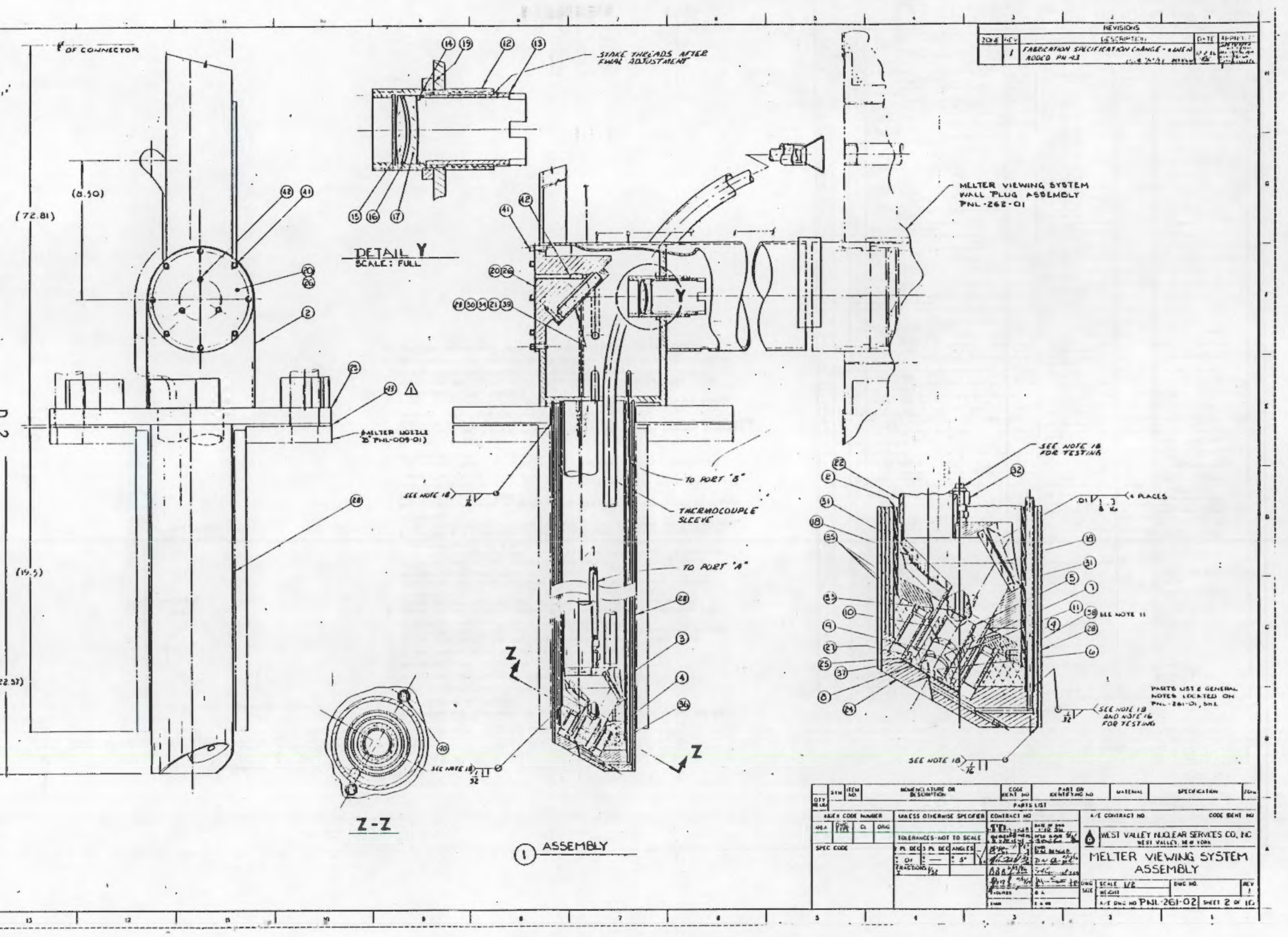



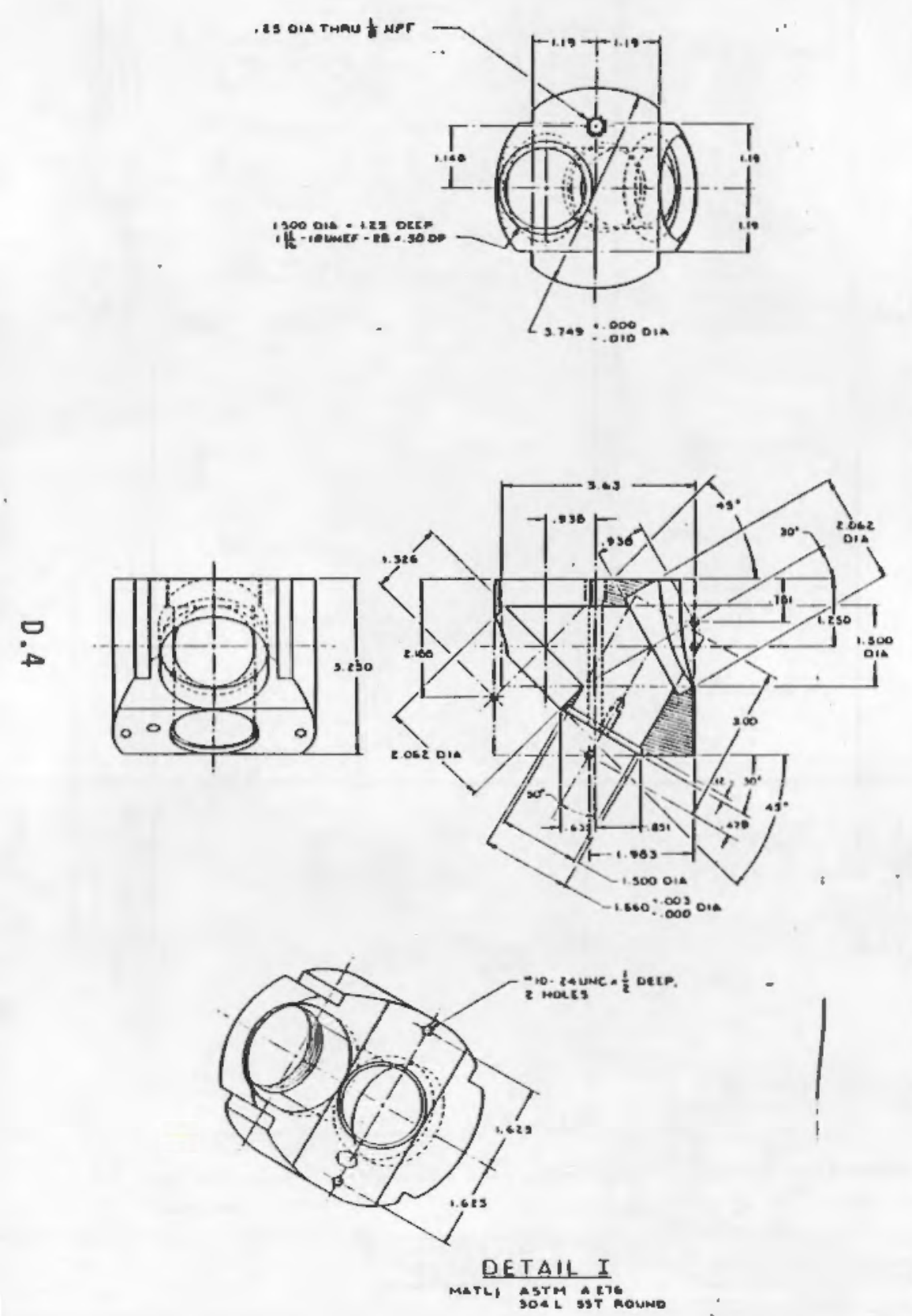

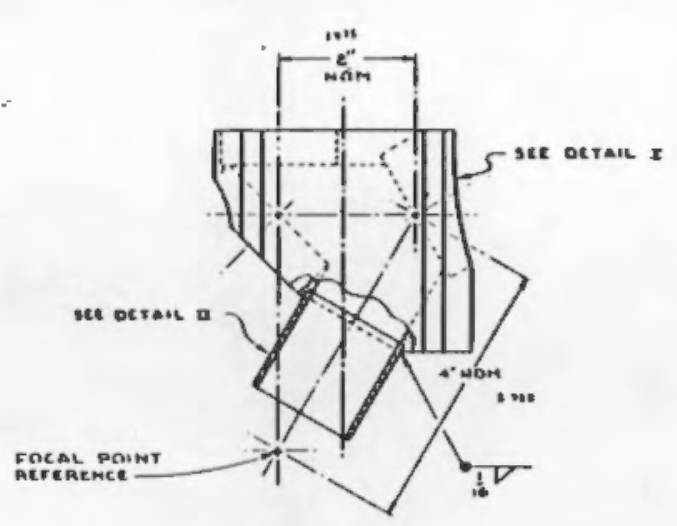

(3) MIRROR HOUSING

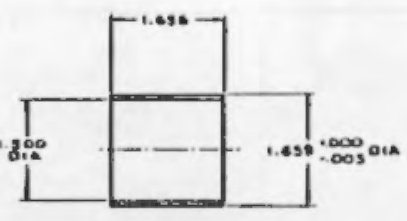

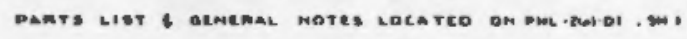

$\frac{\text { DETAIL II }}{\text { math } 900 \text { scenss SST }}$

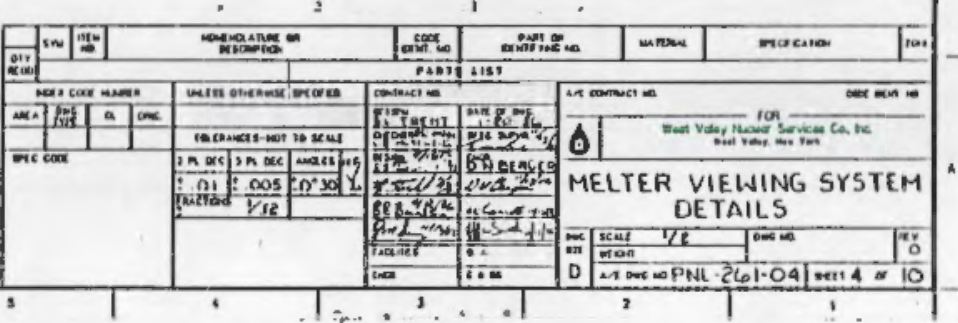




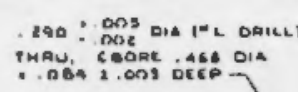

$\cdot-\perp$

1
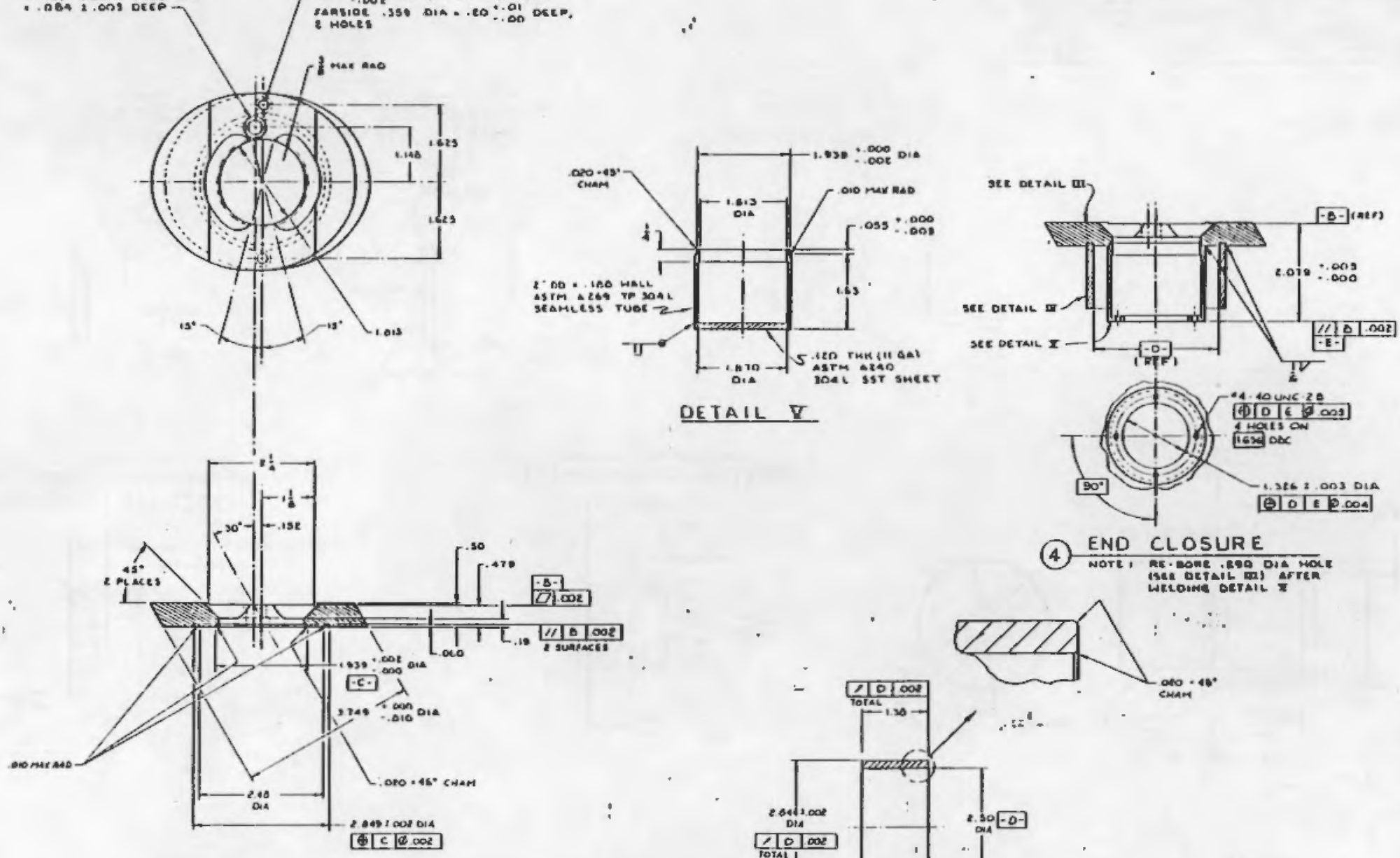

DETAIL III-

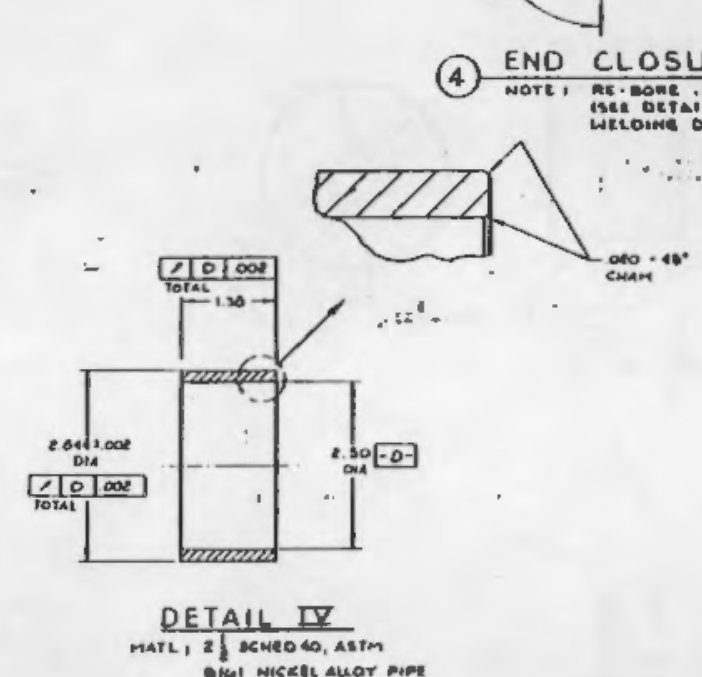

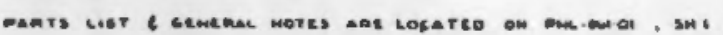

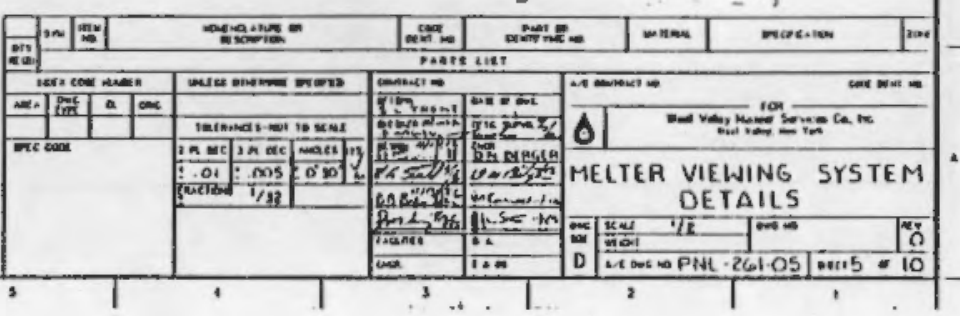




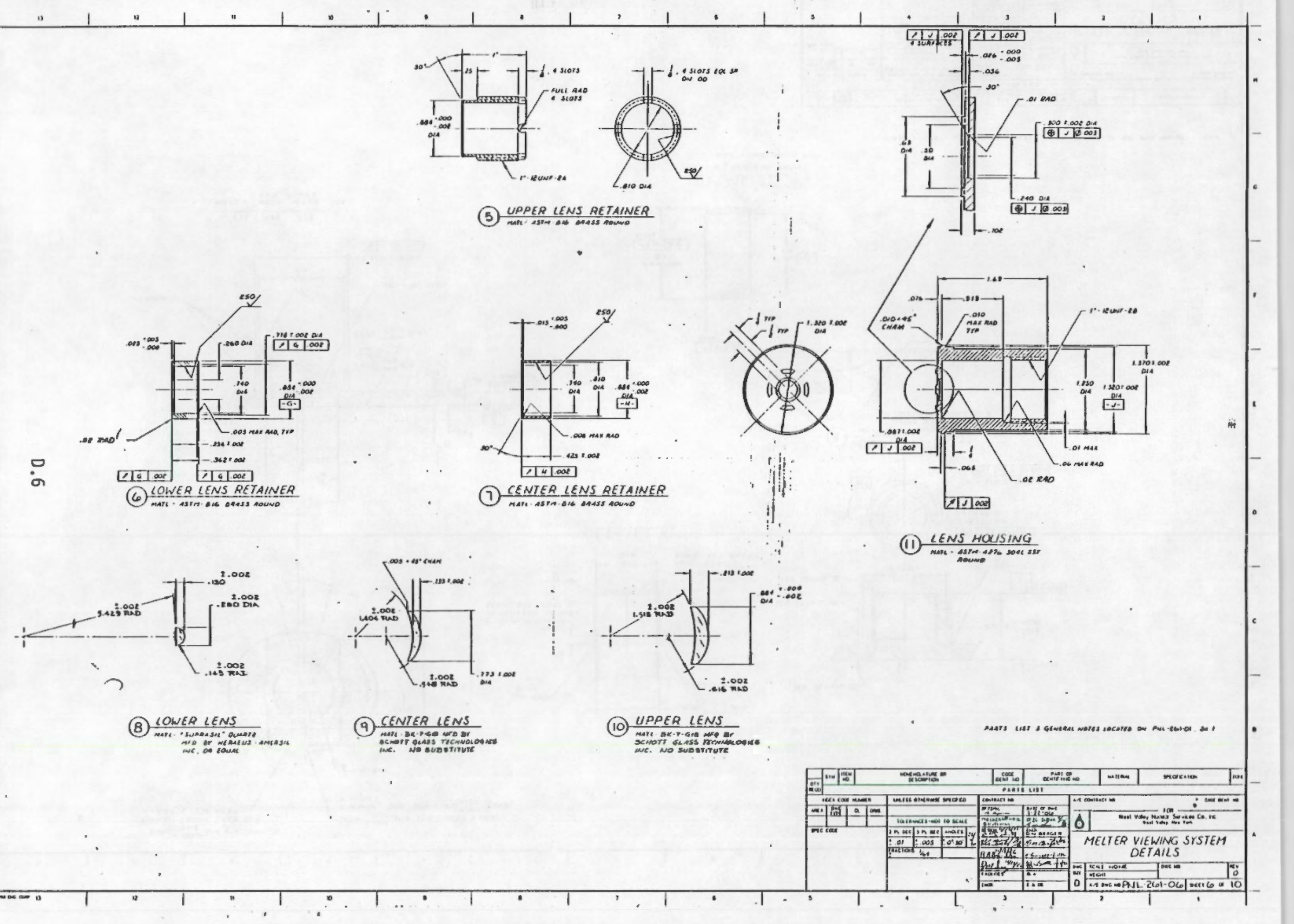



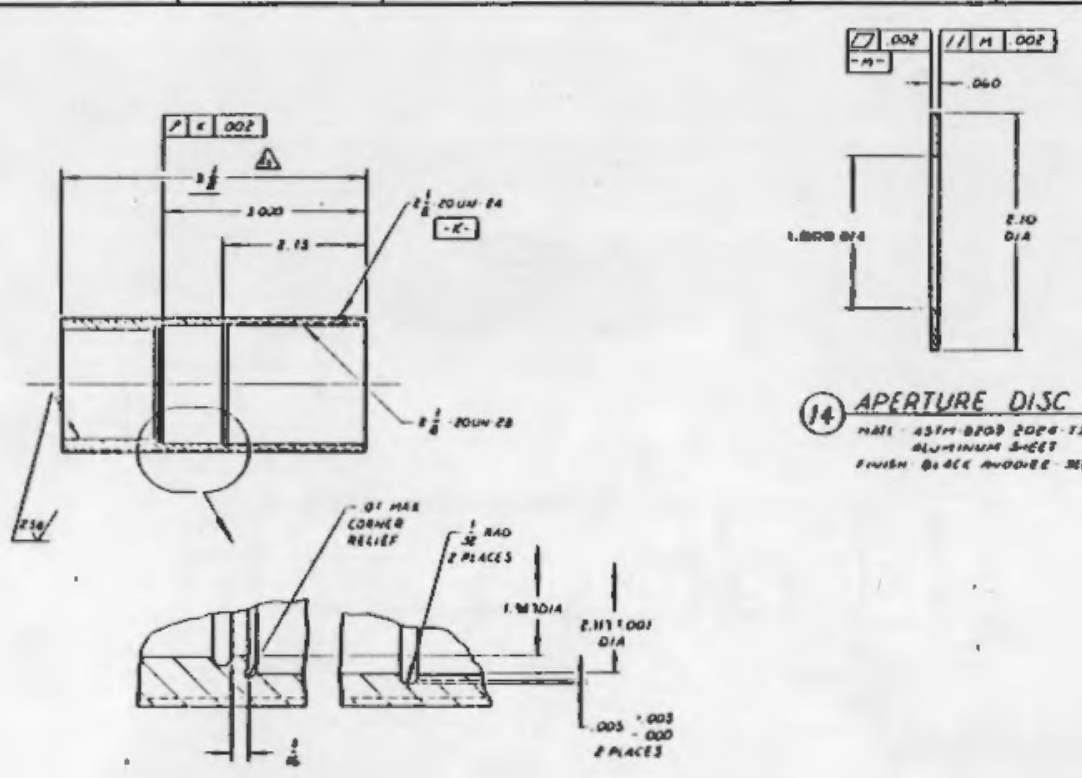

(14) APERTURE DISC

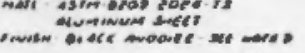
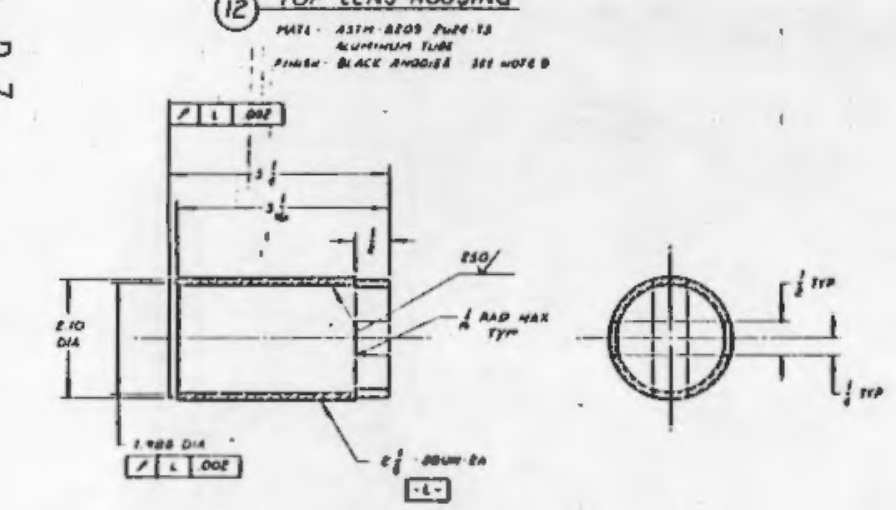

(13) JAM SCREW
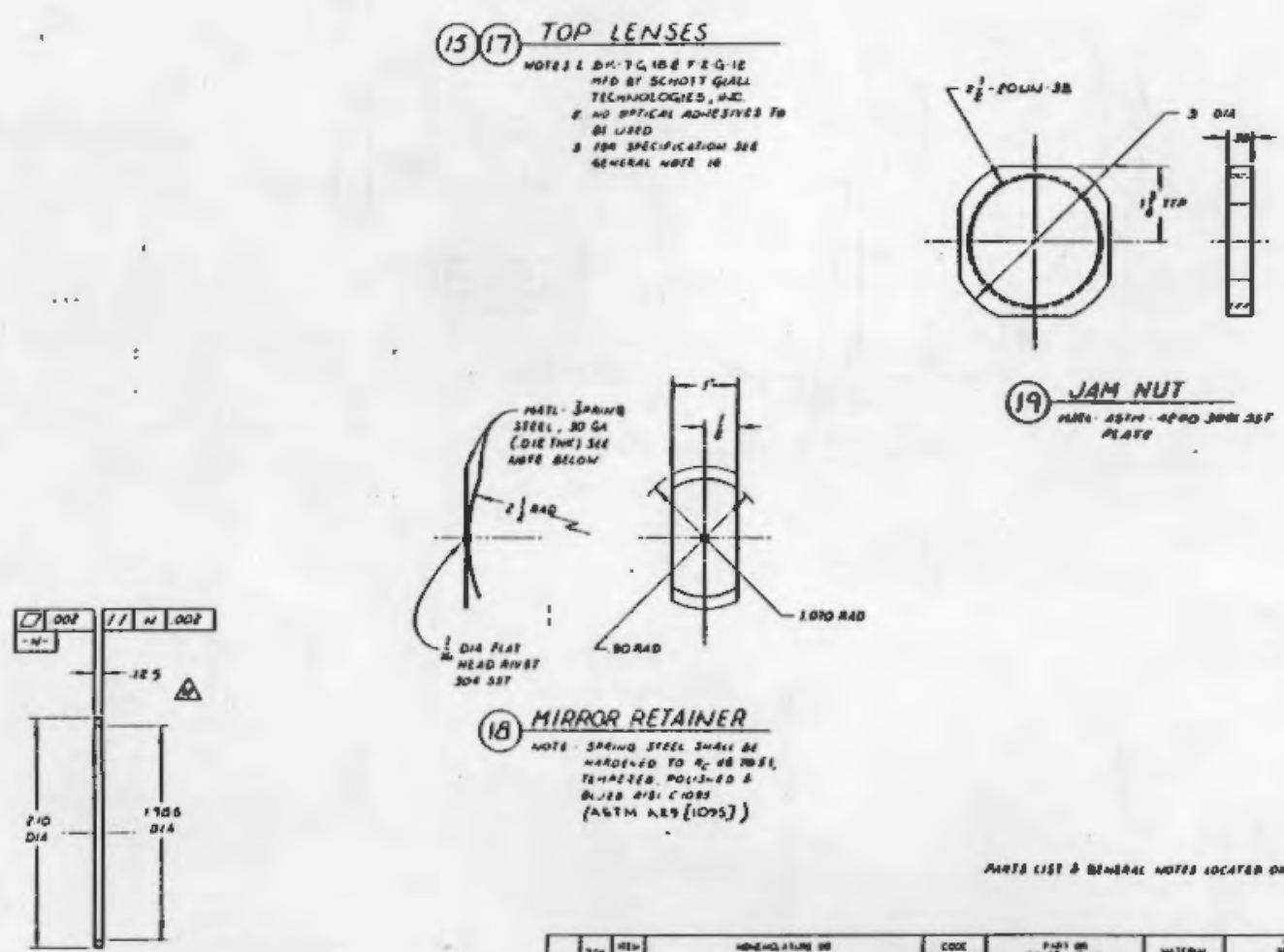

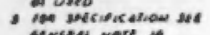

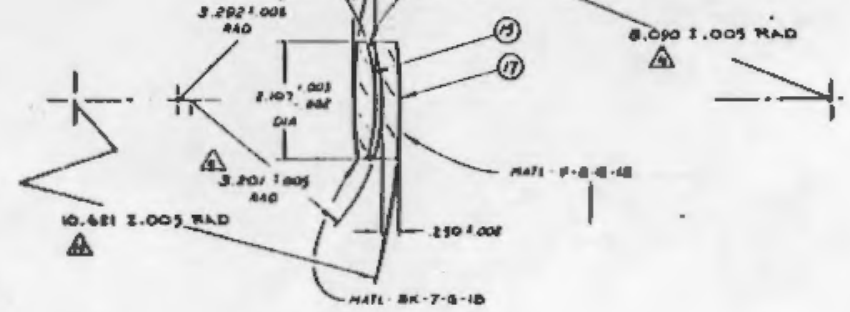

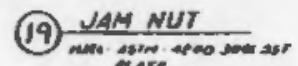

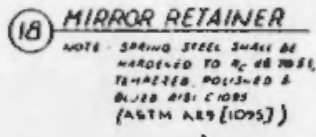

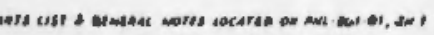




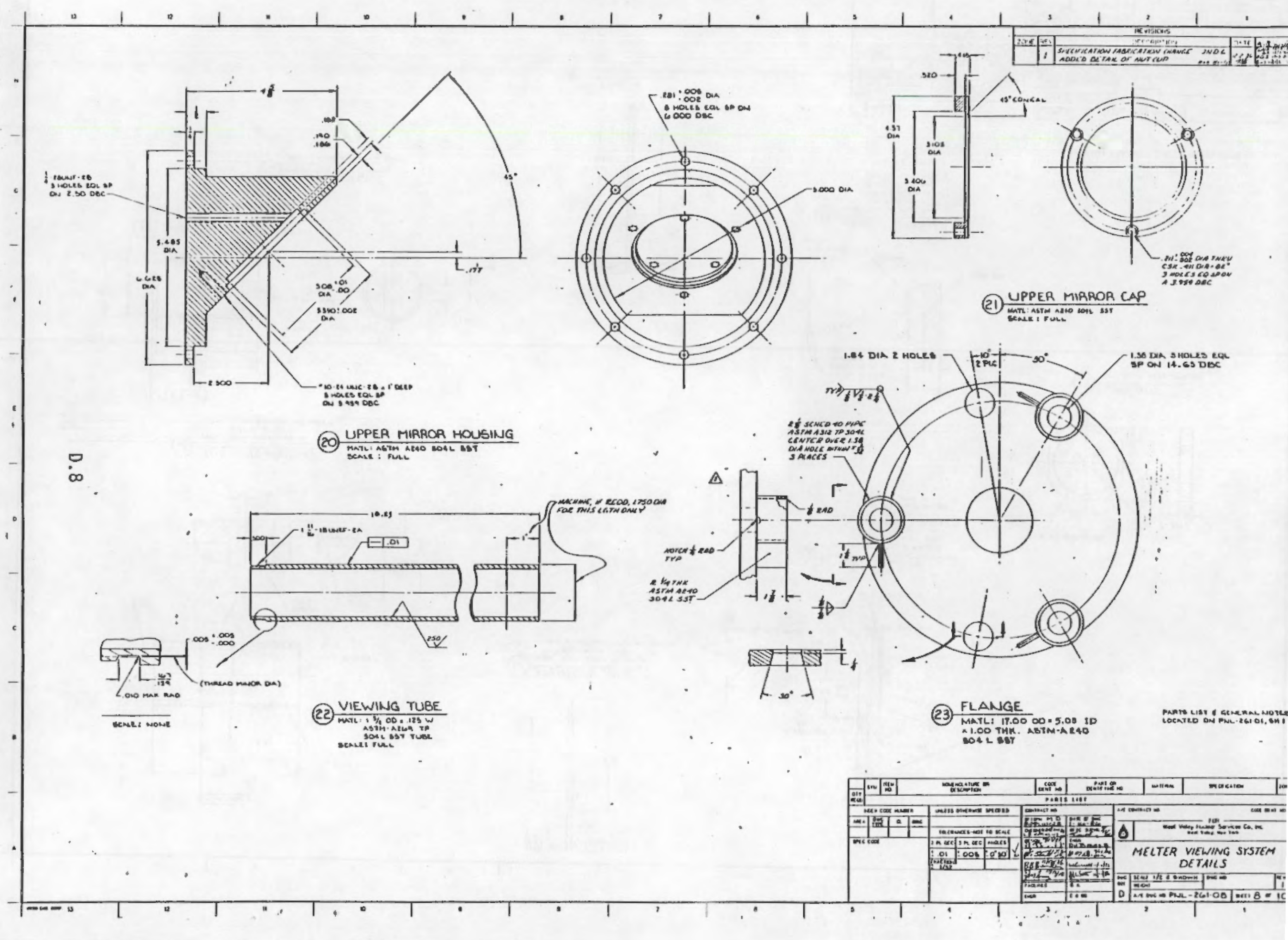




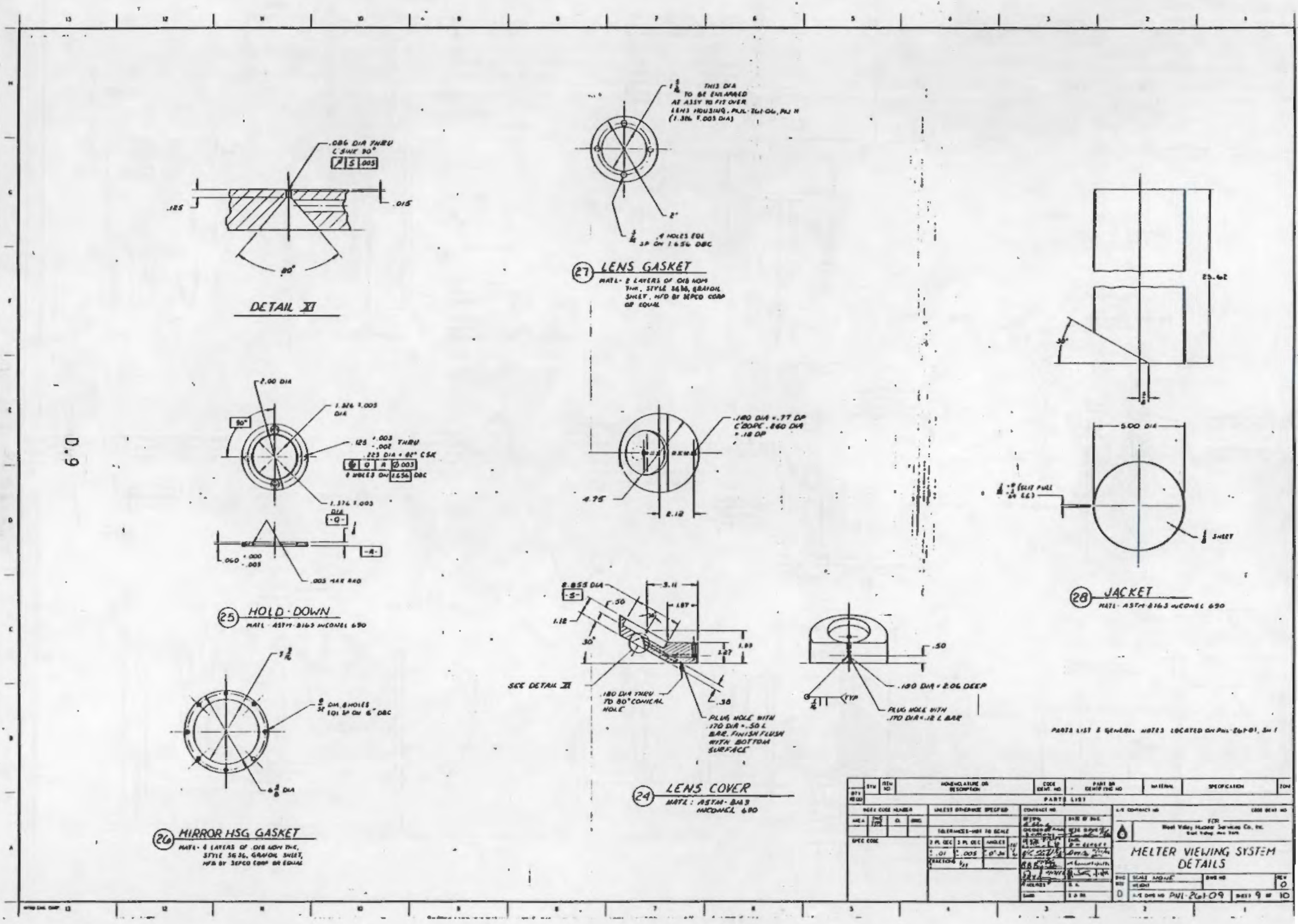




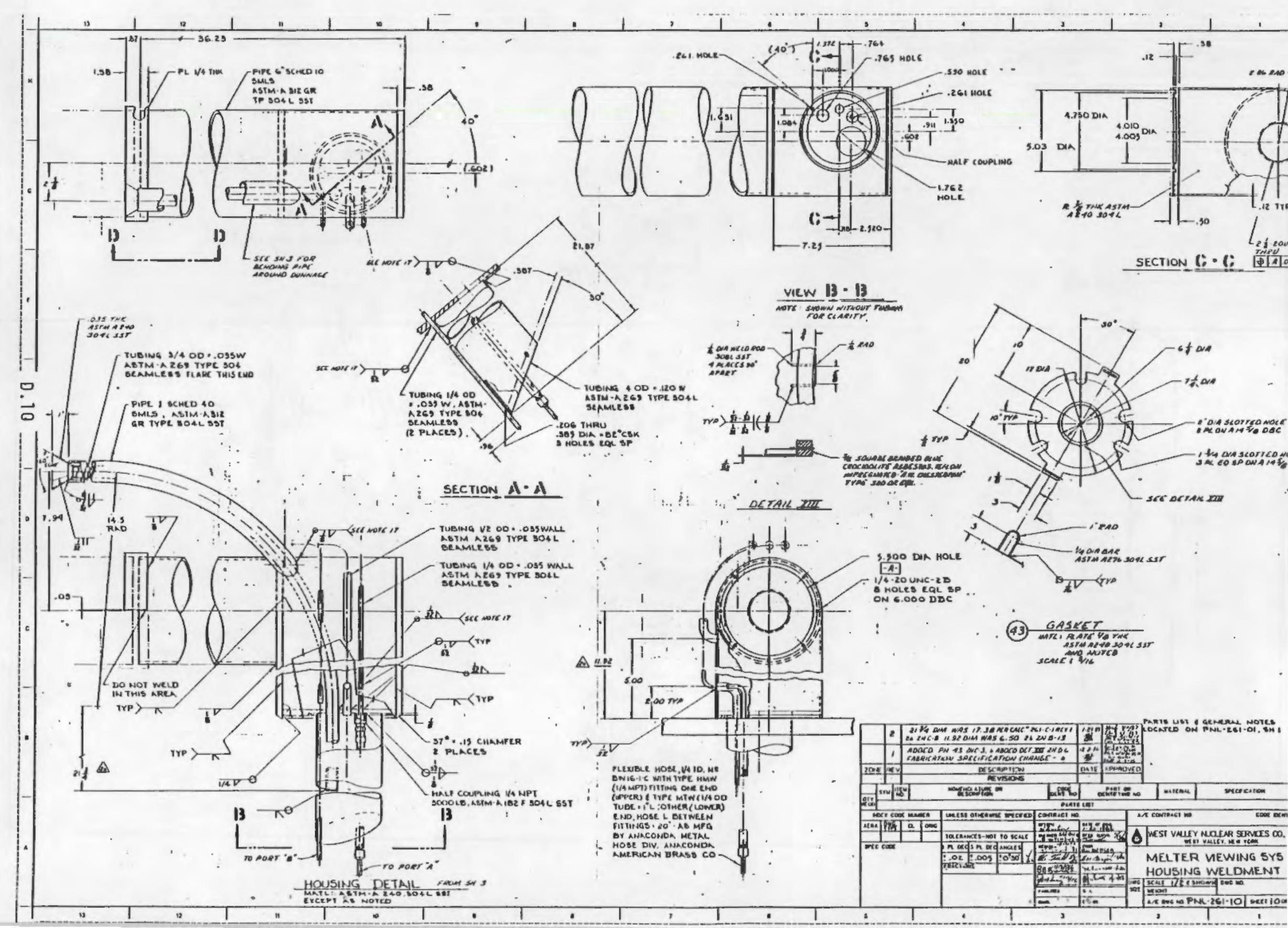




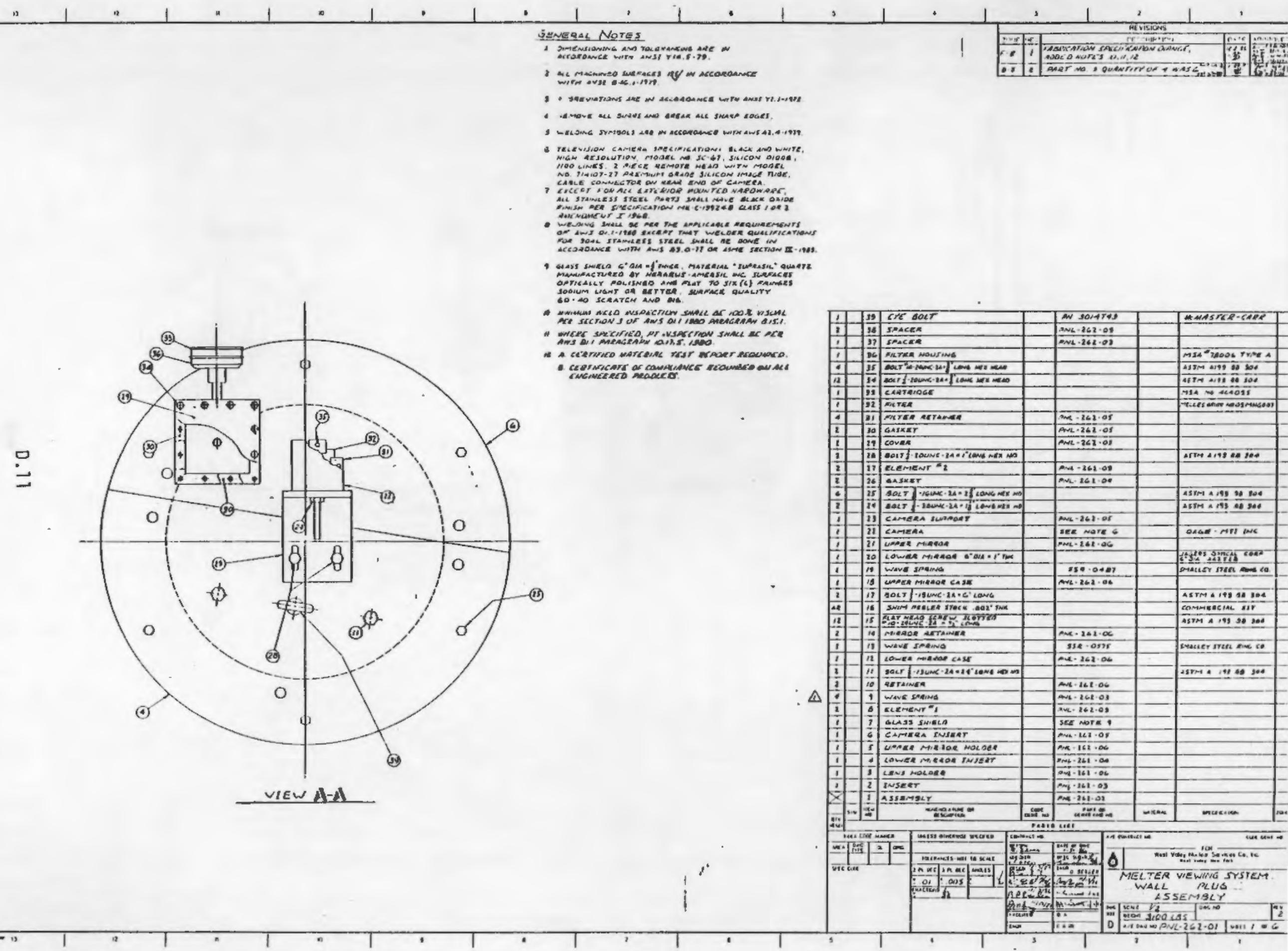




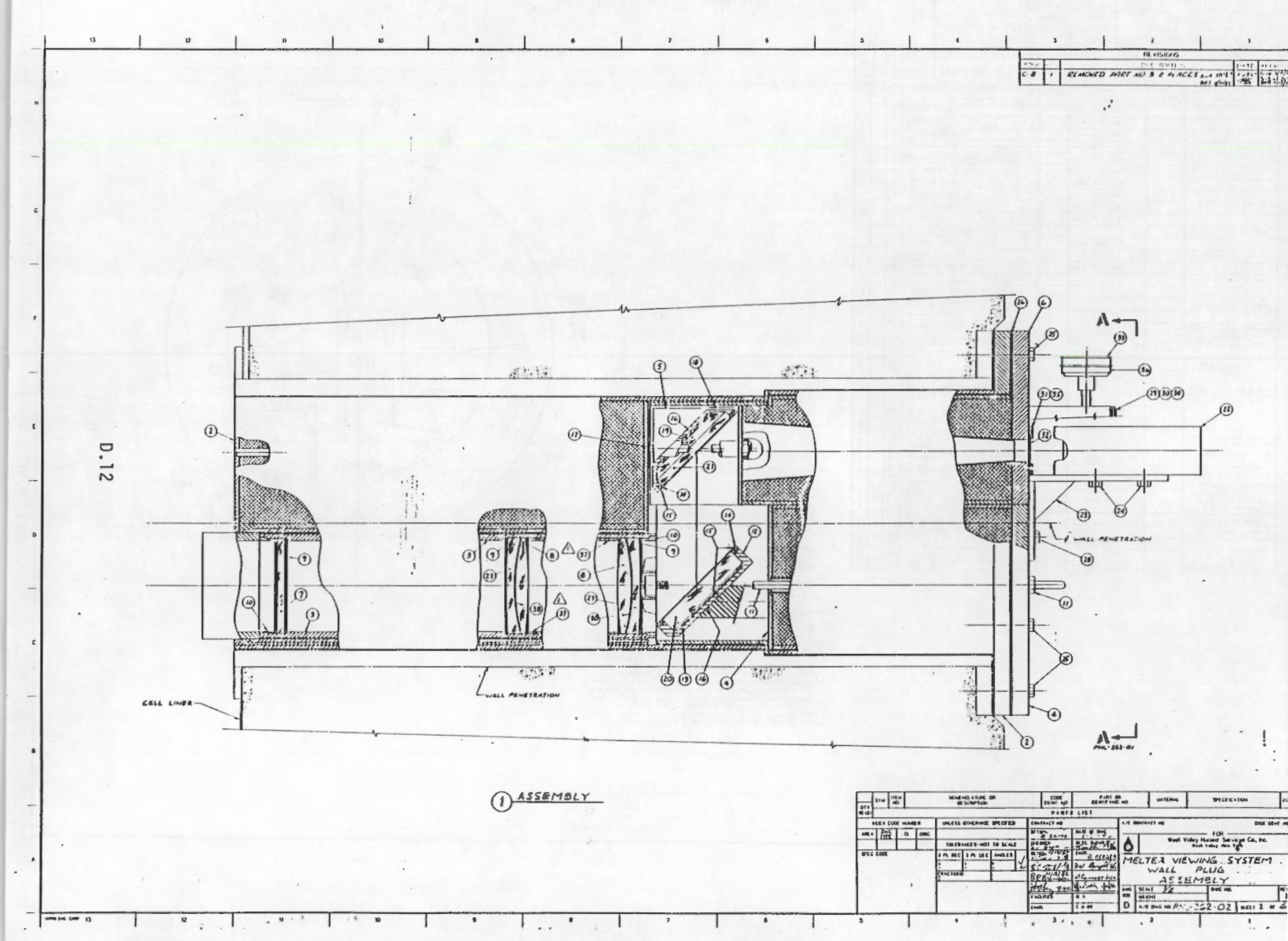




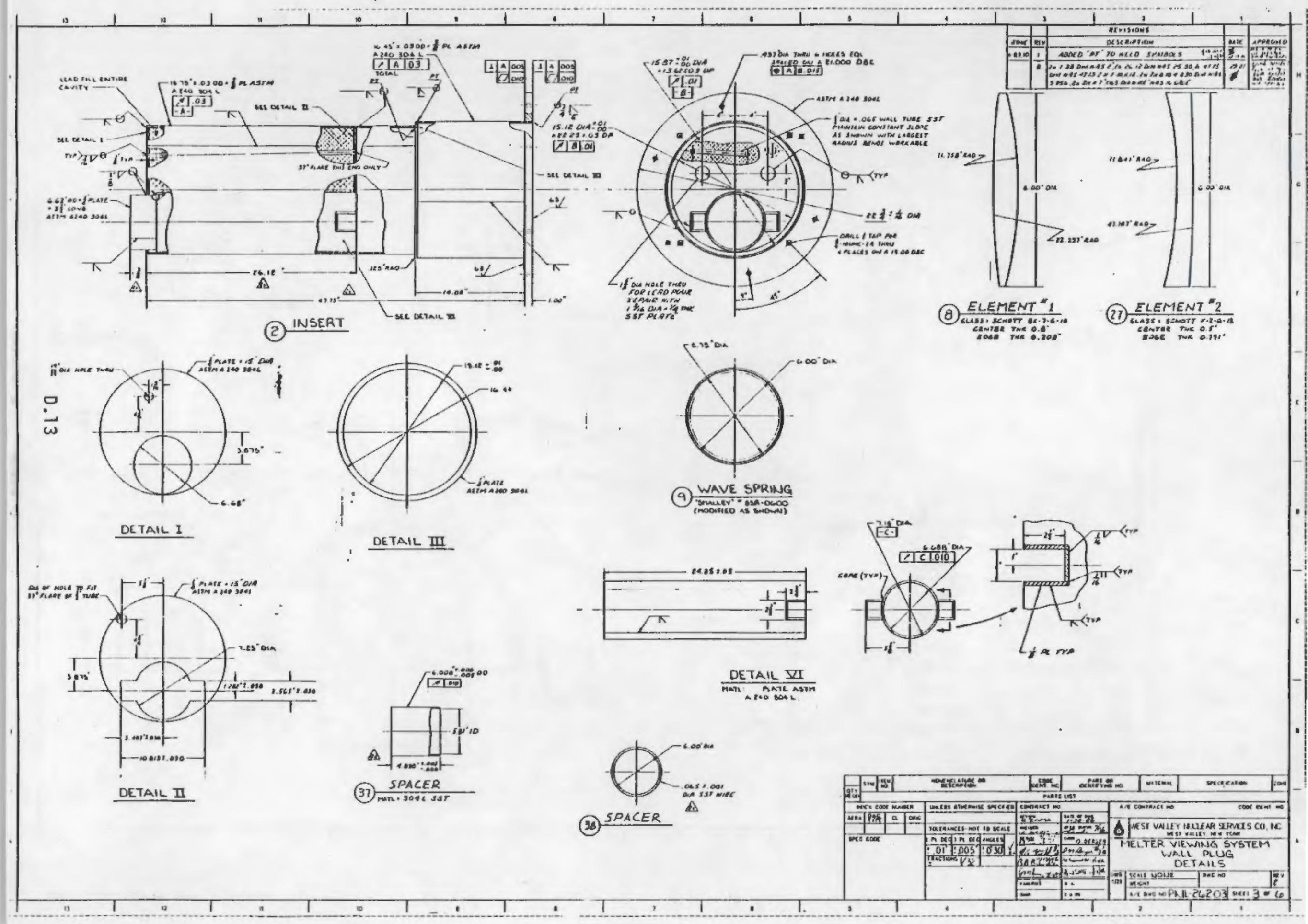




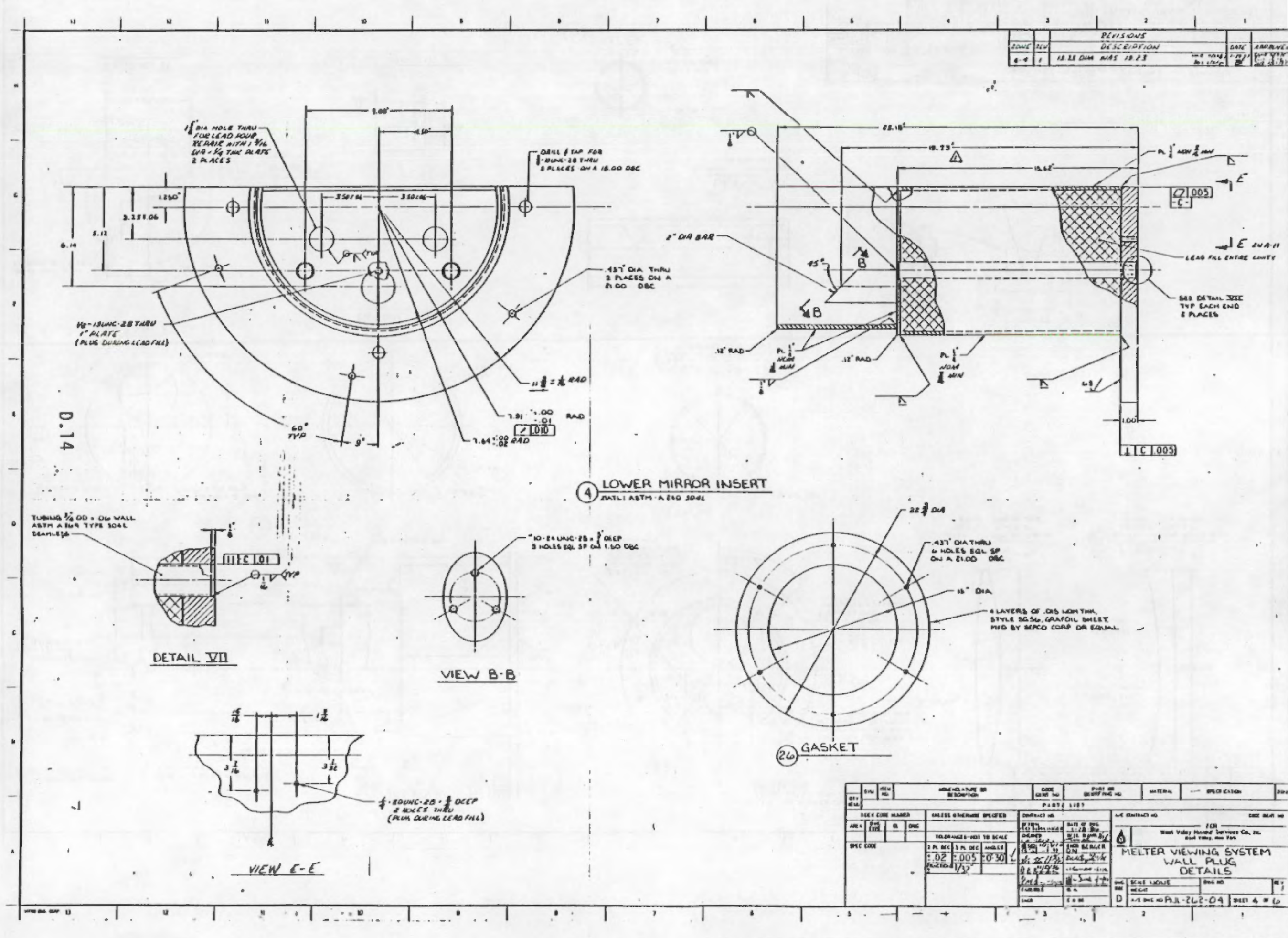




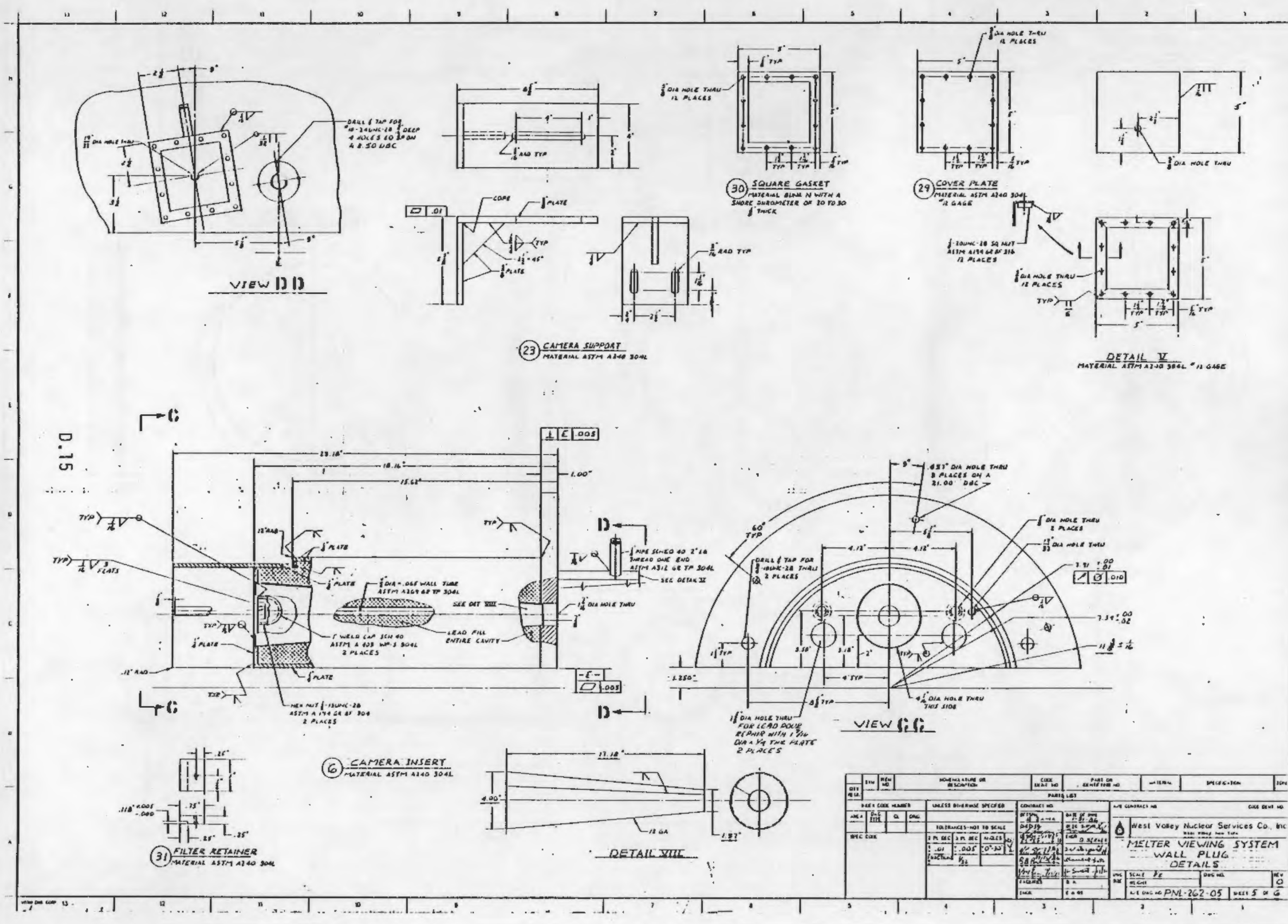




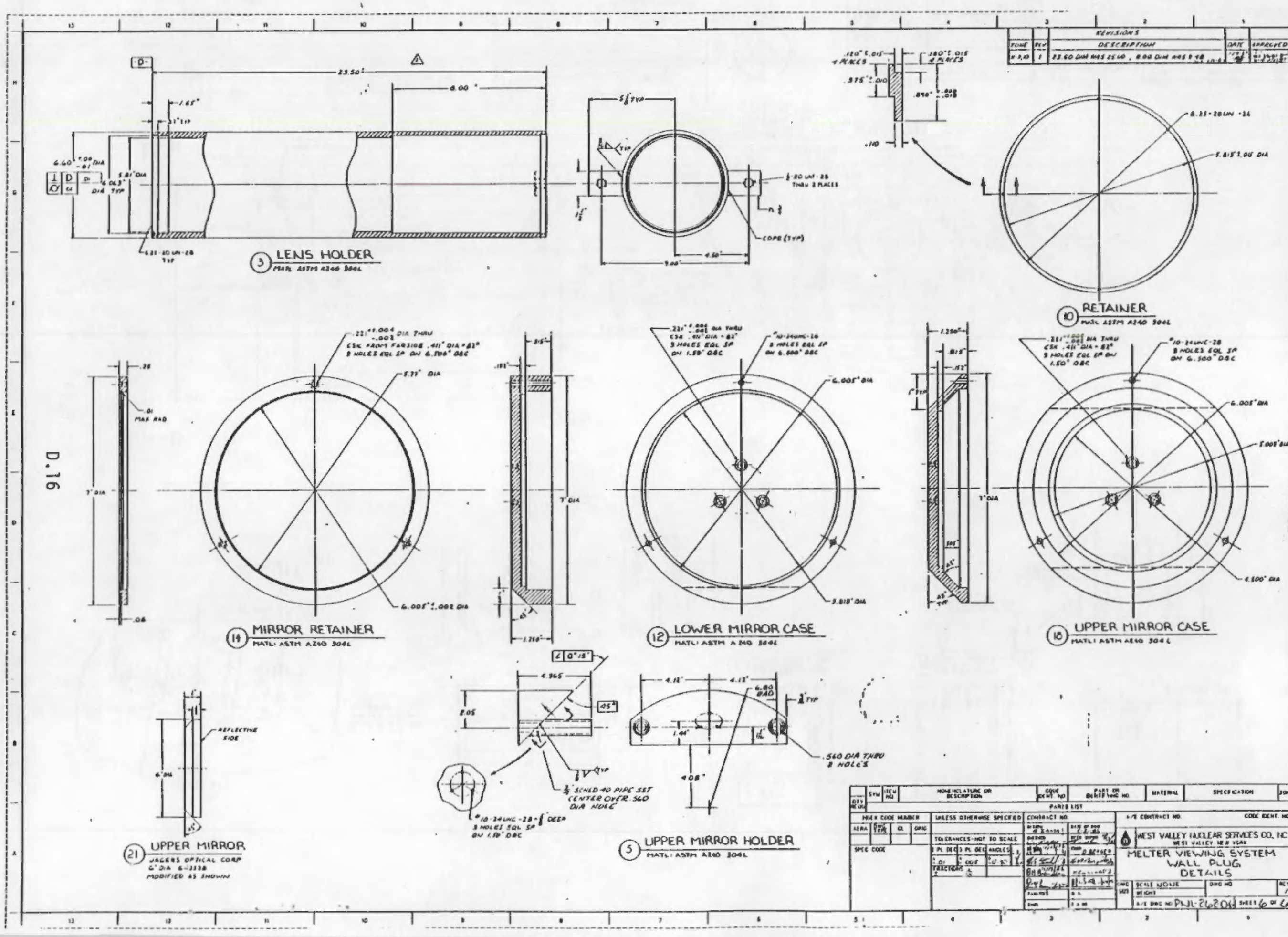




\section{APPENDIX E}

NEW PNL CAMERA DESIGN 


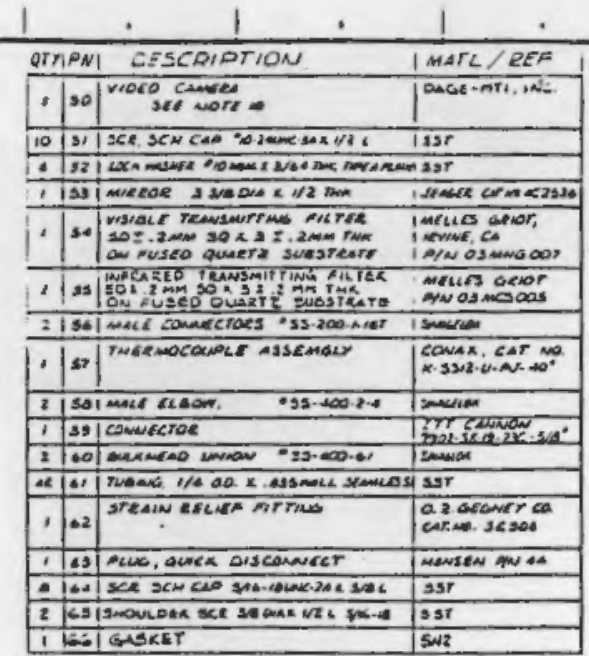

\section{GENERAL NOTES}

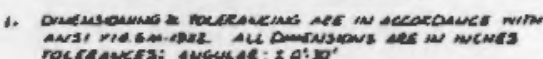

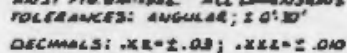

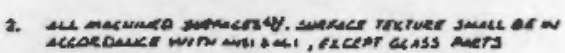

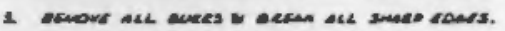

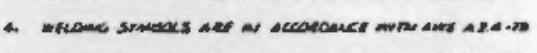

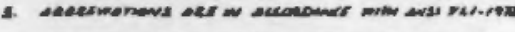

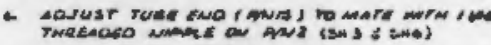

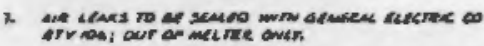

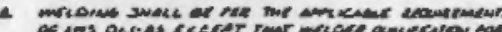

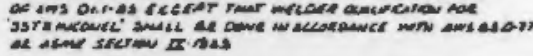

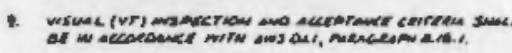

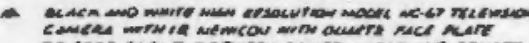

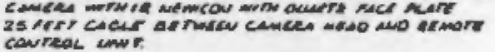

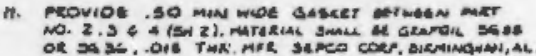

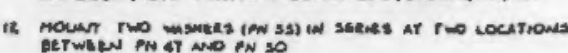

\begin{tabular}{|c|c|c|}
\hline grraw & WI DEẌZIPTION & $1 \mathrm{MATL} / \mathrm{REF}$ \\
\hline 区. & Assemeir & \\
\hline $4:$ & 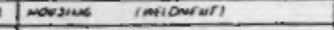 & 300 \\
\hline .13 & coure veore & 20 \\
\hline 1.5 & corke, cumpe & $\sin$ \\
\hline 13 & Tues ciurre & 3046 \\
\hline 2 & 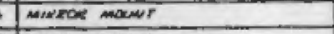 & 3004 \\
\hline & Laws mavsems & sums \\
\hline 18 & Ifars eframse, veofe & $3 \mathrm{sm}$ \\
\hline 1. & 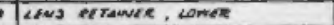 & $2 m s$ \\
\hline 1.0 & 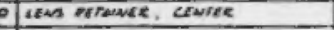 & 3 No \\
\hline & Lfors. comen & \\
\hline $.1 / 2$ & IfENA CENTER & 3 ins \\
\hline 1.13 & afous weree & 20 \\
\hline . I. & 4 thes, arres & sms \\
\hline \begin{tabular}{|l|l|l|}
$1 / 3$ \\
\end{tabular} & 9 Troes, wate & 9me \\
\hline \begin{tabular}{|l|l|l|}
14 \\
\end{tabular} & Rate, afrawing & 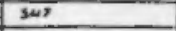 \\
\hline .6 & isumader nume & $\sin$ \\
\hline 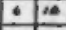 & $1 \sin x=0$ & se7 \\
\hline 19 & jeased & 3207 \\
\hline 1.20 & 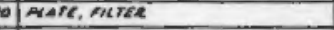 & sw) \\
\hline 122 & 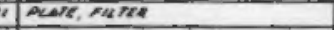 & 320 \\
\hline & 2] 2 ens noestines & $3 \times 8$ \\
\hline 123 & 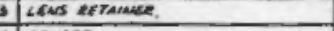 & $\sin 0$ \\
\hline-126 & 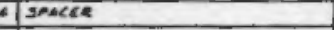 & 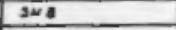 \\
\hline $1 / 28$ & St was samater & $\sin 0$ \\
\hline 416 & 6 ISA3. TOP & $3 \times 8$ \\
\hline 127 & 17. Leas, sorton & 300 \\
\hline $2 \pi$ & 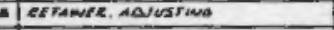 & $\sin 7$ \\
\hline$\pi$ & 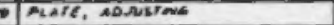 & swos \\
\hline 15 & of mown r, camers. & $\operatorname{sen} 1$ \\
\hline \begin{tabular}{|l|l|l|}
5 \\
\end{tabular} & 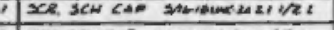 & ssr \\
\hline$-1 / 2$ & 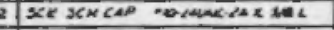 & $23 \%$ \\
\hline-1 as & 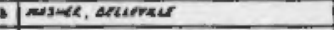 & 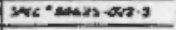 \\
\hline-130 & 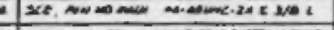 & $3 s \mathbf{r}$ \\
\hline-19 & 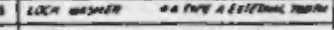 & $33 r$ \\
\hline 1.36 & Nordounc.20 & gyr \\
\hline$\cdot[37$ & 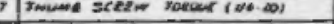 & atros $60 \mathrm{CO}$ \\
\hline[]$^{30}$ & 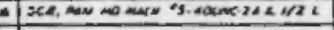 & 然 \\
\hline$-[30$ & CR. Asume.2A & 195 \\
\hline 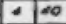 & 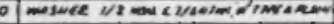 & $33 r$ \\
\hline 3 & 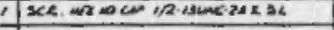 & sar \\
\hline $50 j-2$ & 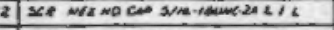 & $23 r$ \\
\hline $24[03$ & 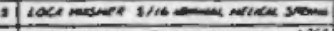 & A3r \\
\hline . 1.0 & A & 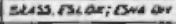 \\
\hline 12 |es & 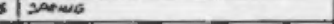 & 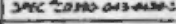 \\
\hline 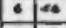 & 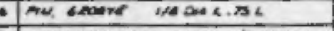 & $2 s r$ \\
\hline 2 & 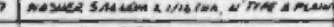 & s5T \\
\hline$[.] \cdot 4$ & 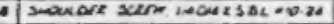 & 357 \\
\hline & 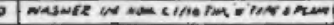 & $3 s 5$ \\
\hline
\end{tabular}




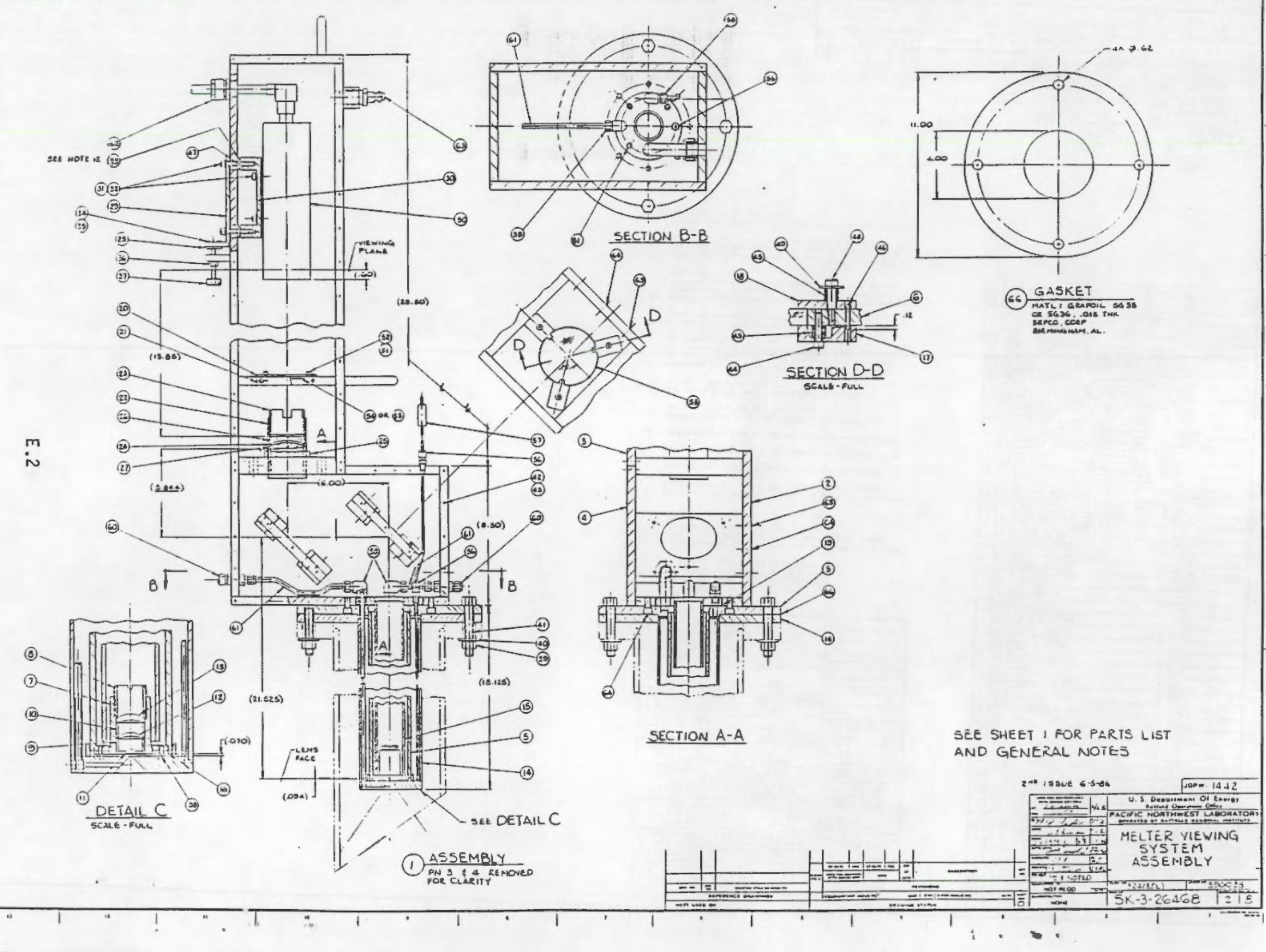




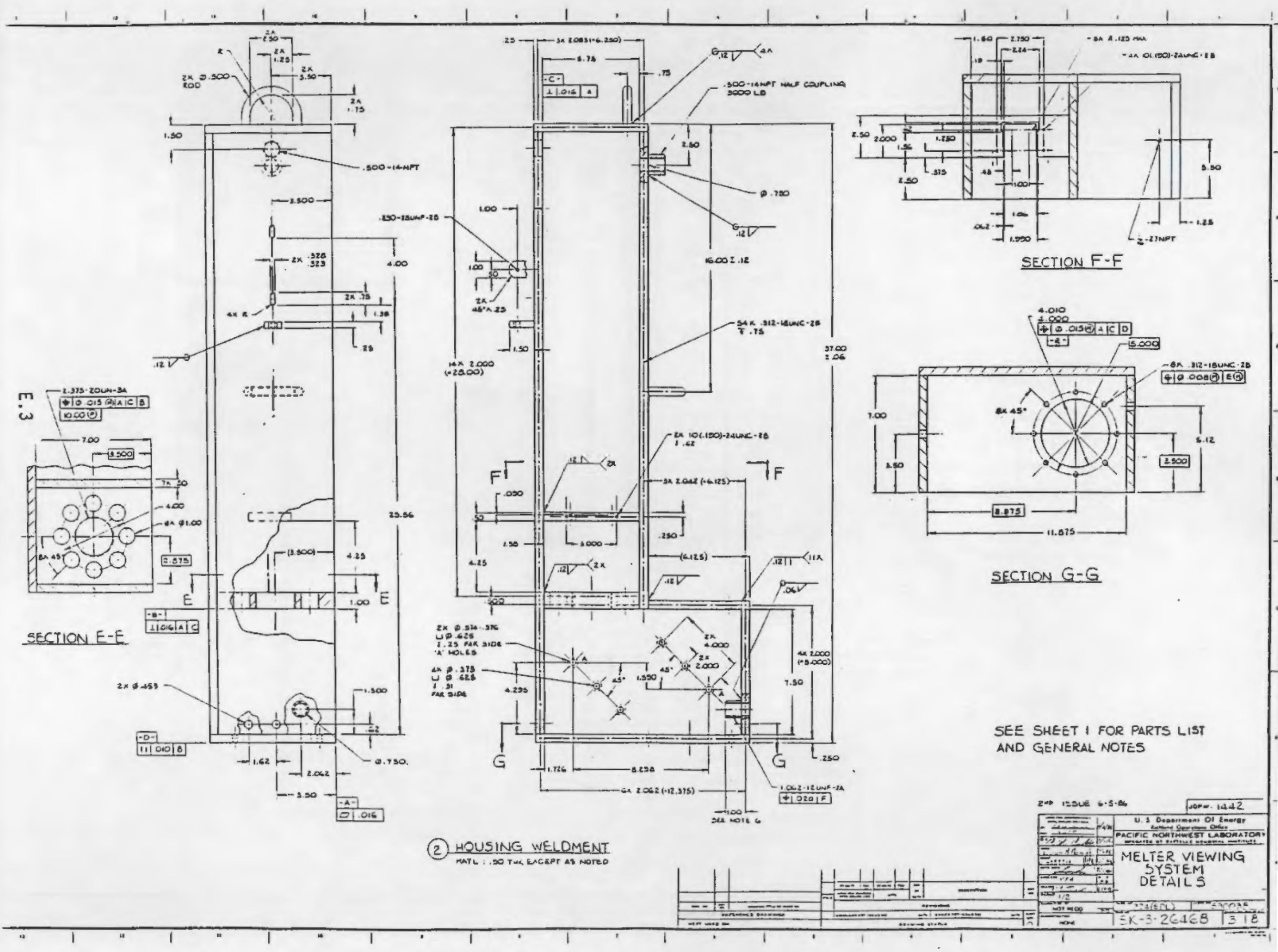




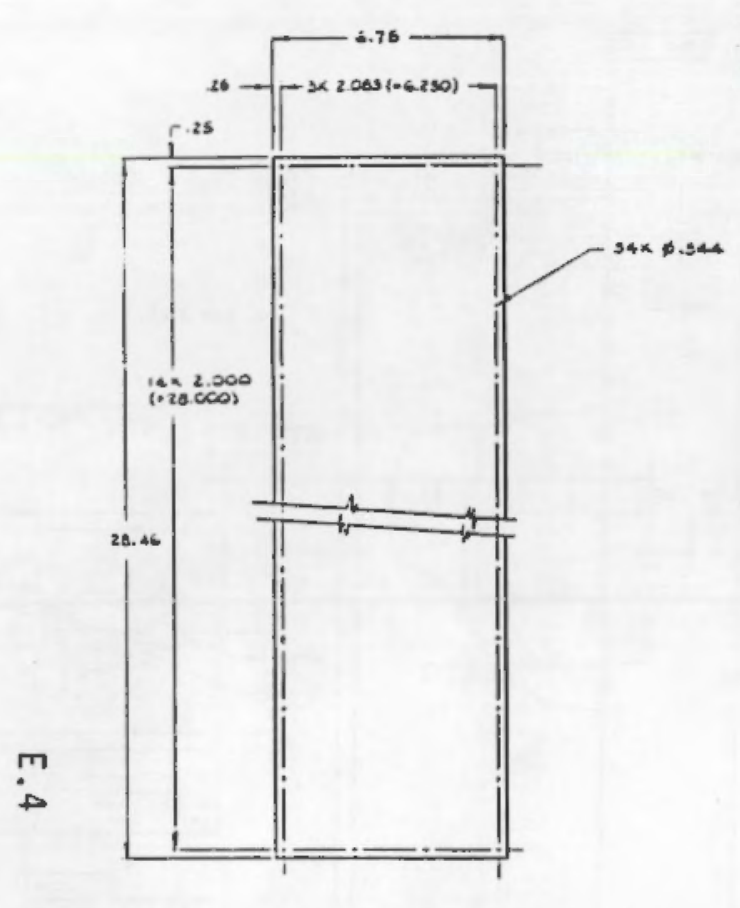

\section{(3) COVER, UPPER}

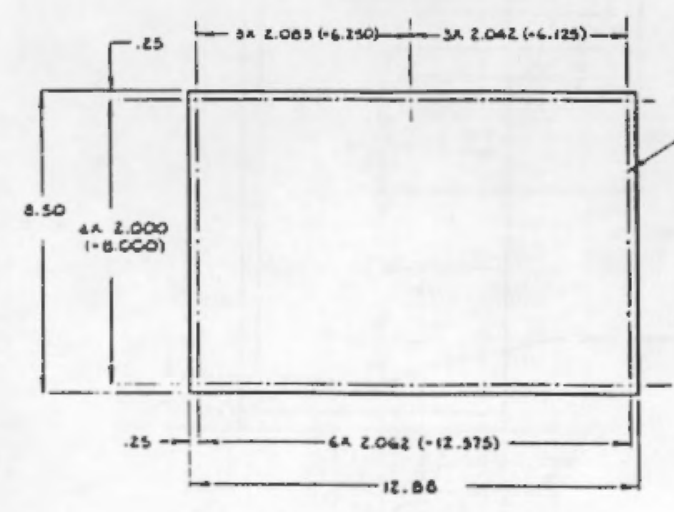

(1) COVER LOWER
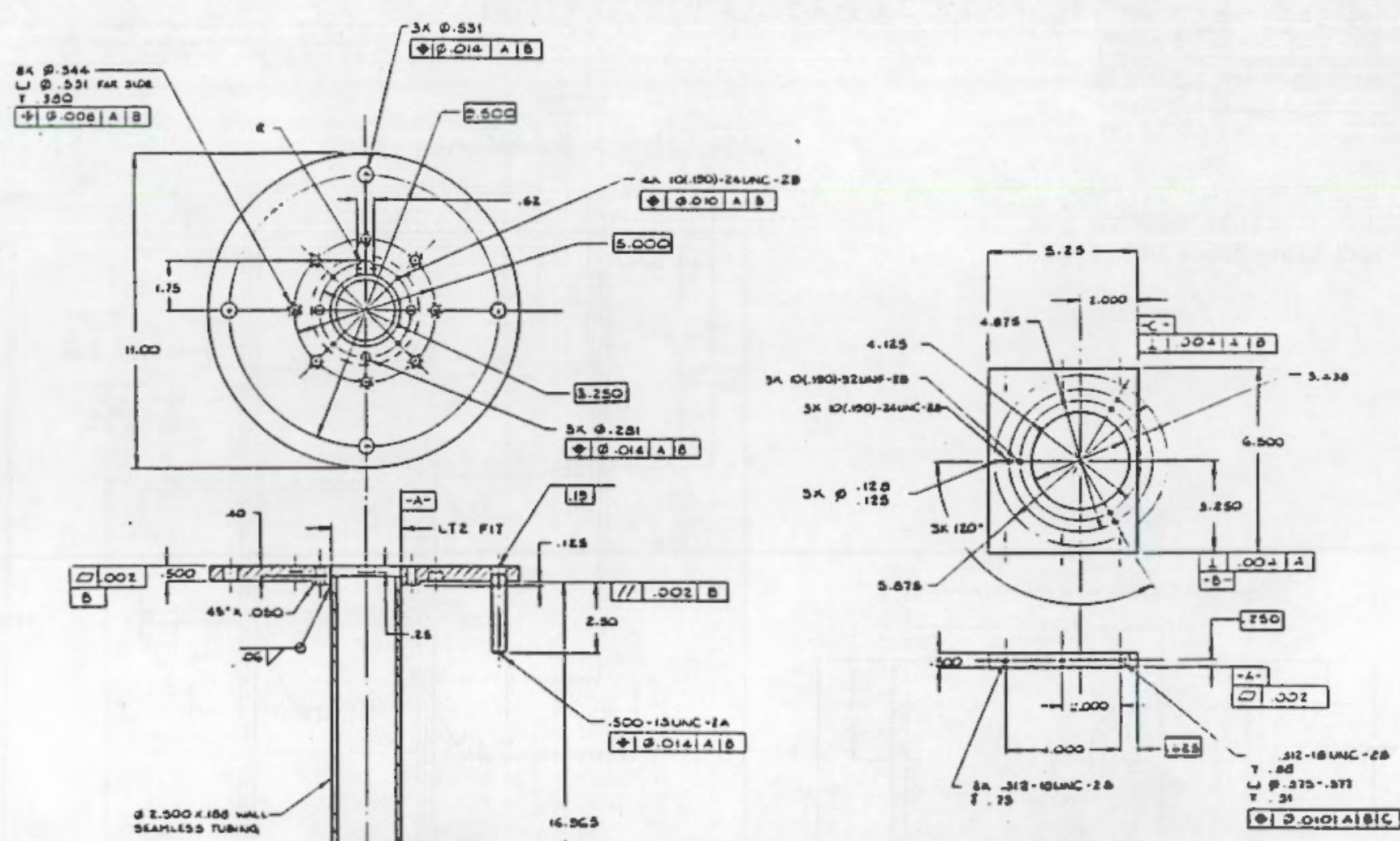

(6) MIRROR MOUNIT

SEE SH I FOR PARTS LIST AND GENERAL NOTES

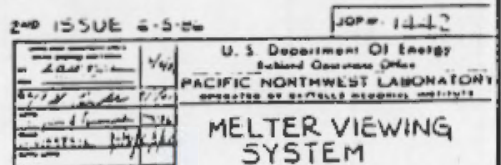
ETH MELTER VIEWIN

(5) TUPE, CENTER

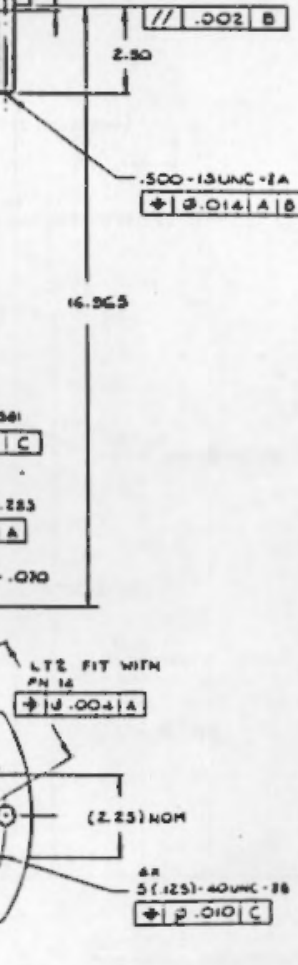

$1=$ DETAILS 

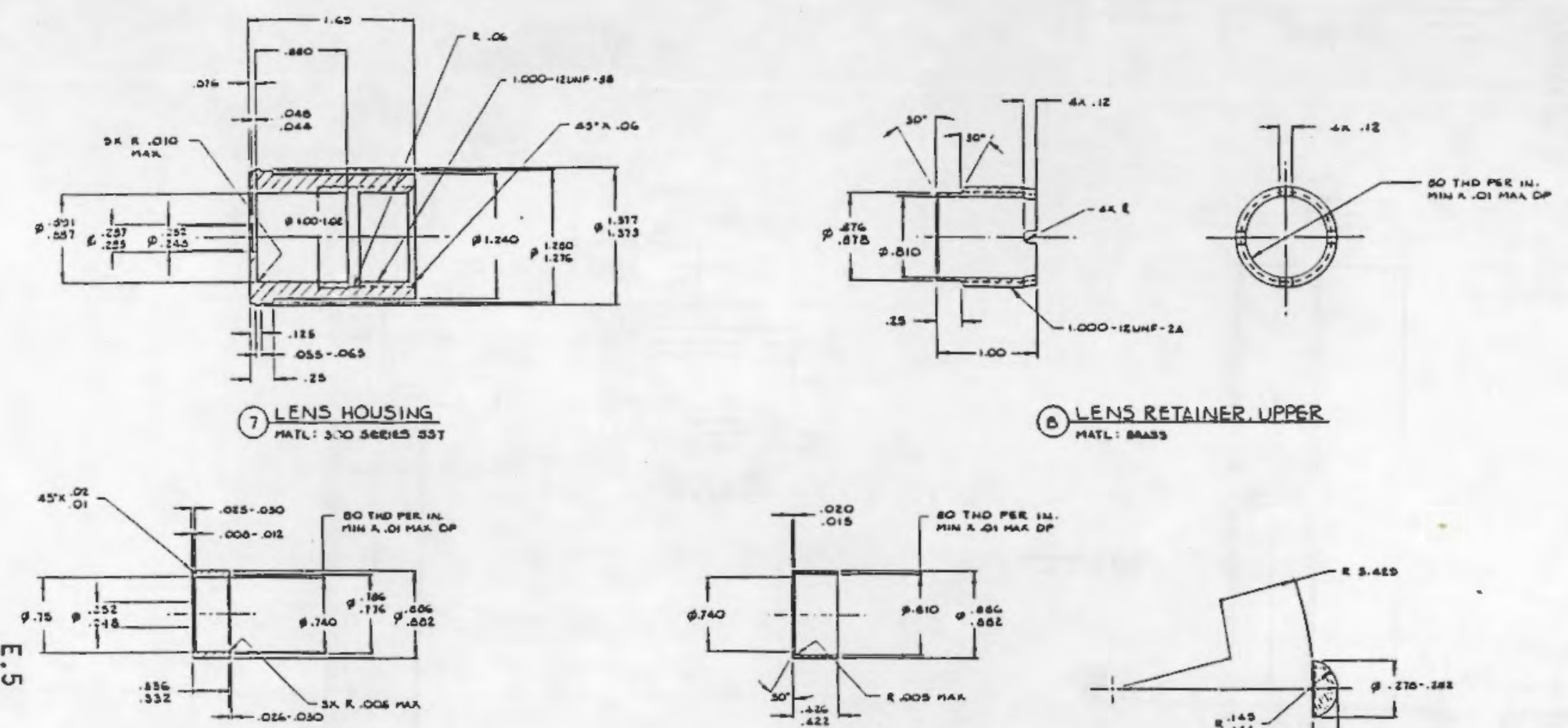

(9) LENS RETAINER, LOWER

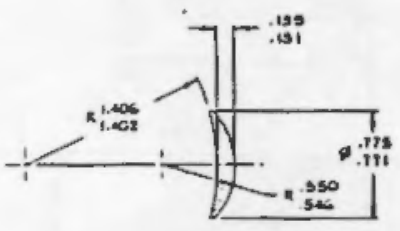

(B) LENS RETAINER, UPPER
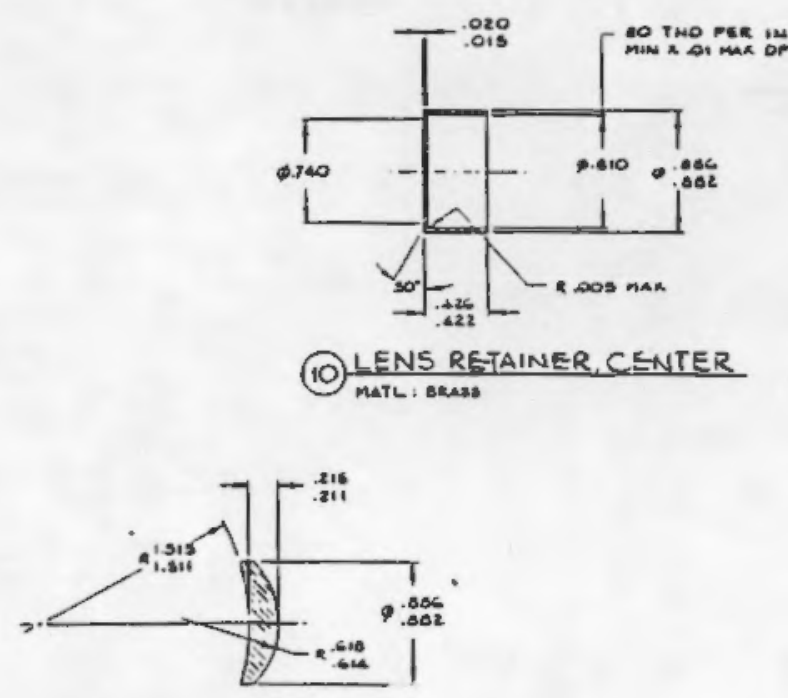
(10) LENS RETAINER, CENTER asc 1

(13) LENS, UPPERR

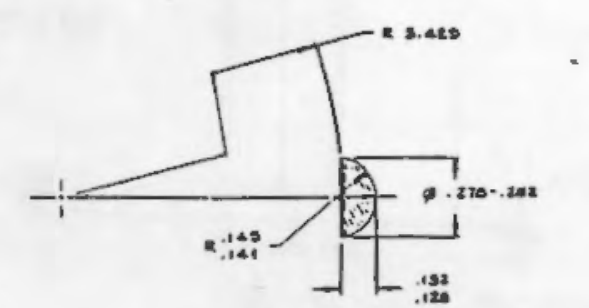

(11) LENS, LOWER

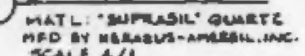

(12) LENS. CENTER (1)

SEE SHEÉT I FOR PARTS LIST AND GENERAL NOTES

20issué 6.5-2.t

rome 1442

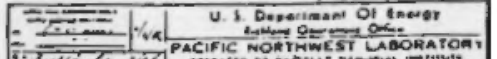

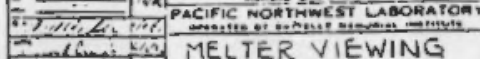
E. MELTER VYM

$H+1=1-1=1$ $1=\frac{2-1}{2-1}$ DETAILS 

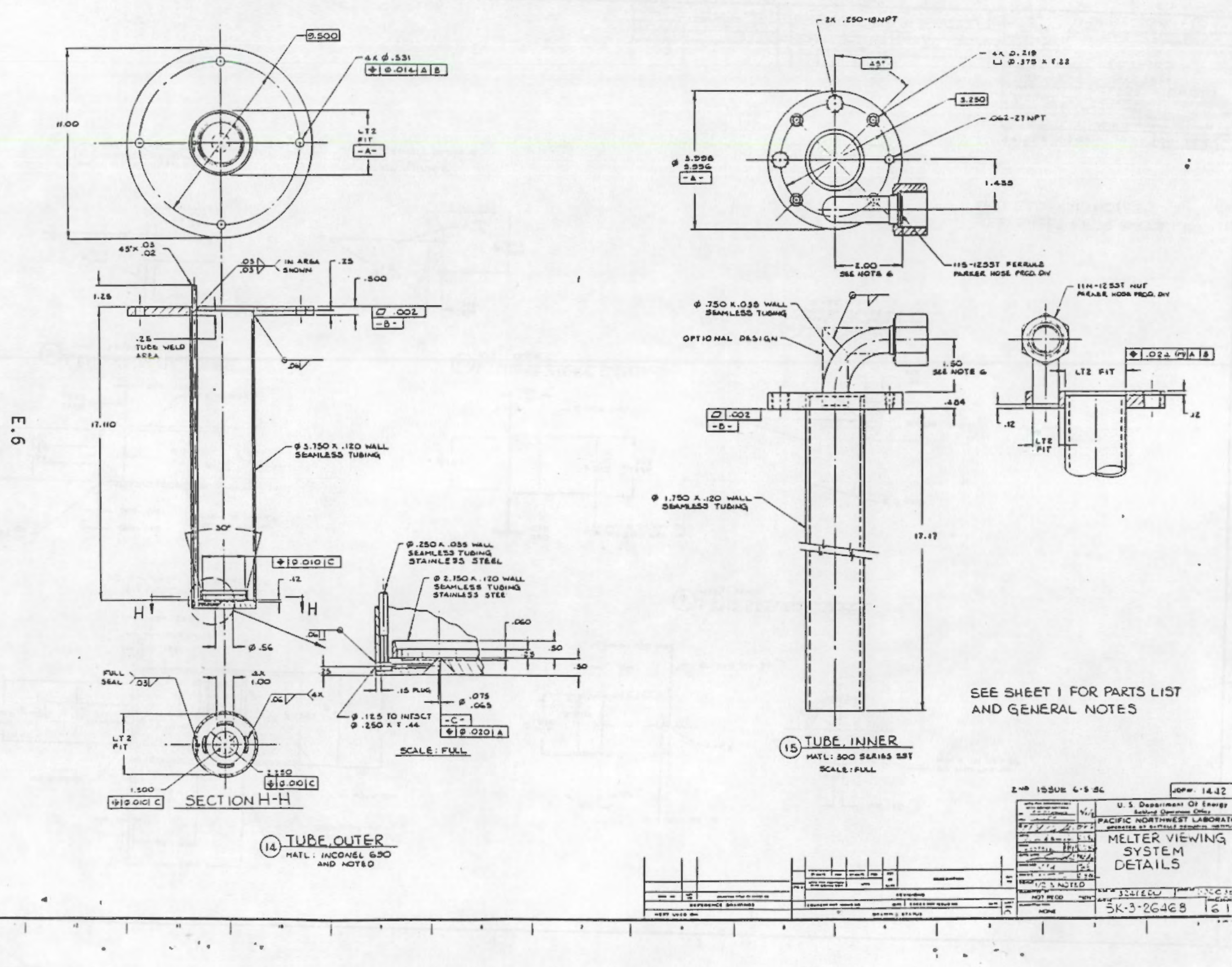


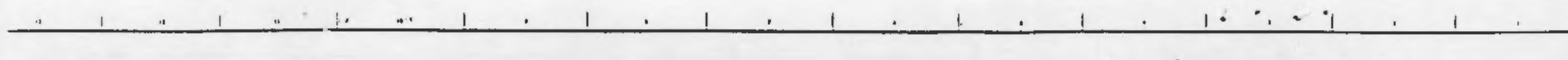

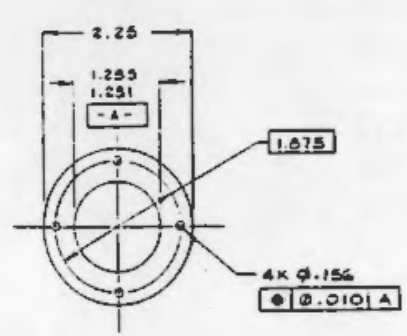

(16) PLATE, RETAINER

m

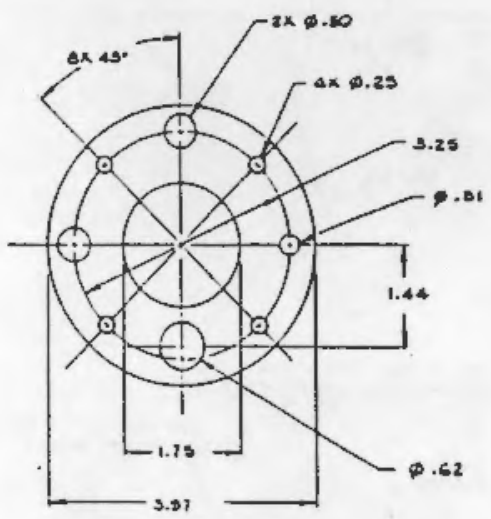
(19) GASKET

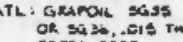

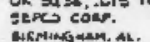
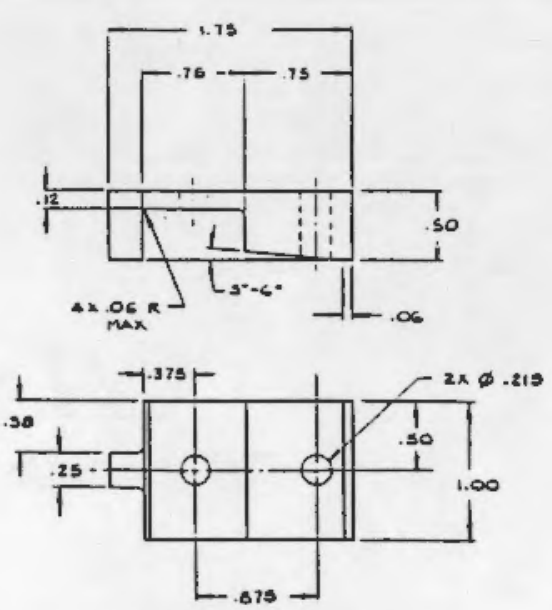

(17) SUPPORT, MIRROR MATL: 300 SERESS SST
SCALE : 24
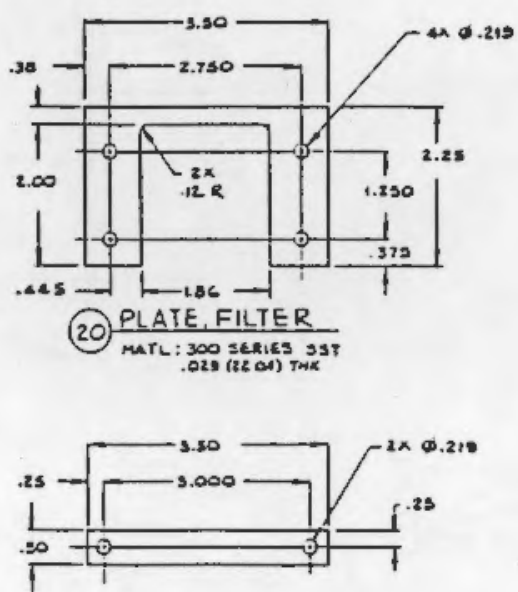

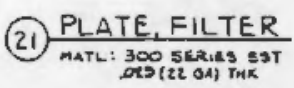

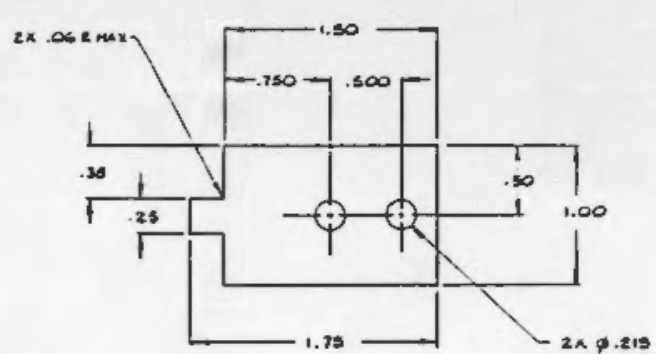

(18) SUPPORT, MIRROR

MATL: 100 SGRils SAT -12 THK serils : 219

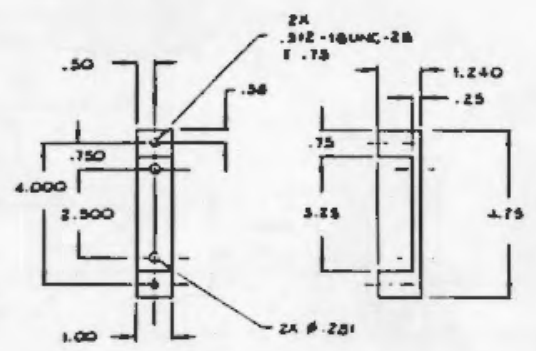

\section{(30) MOUNT, CAMERA}

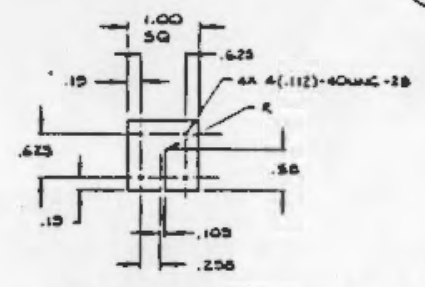

(25) RETAINER, ADUUSTING

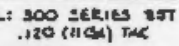

SEE SHEET I FOR PARTS LIST AND GENERAL NOTES 


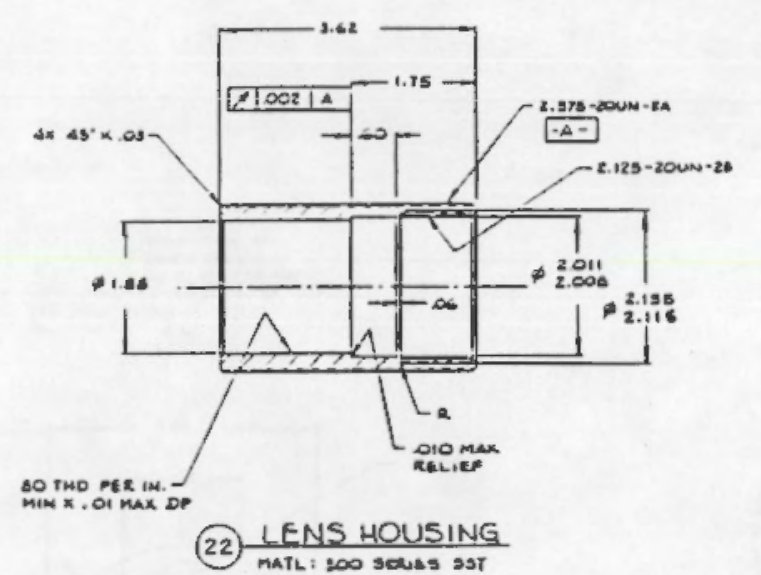

(22) LENS HOUSING

$m$

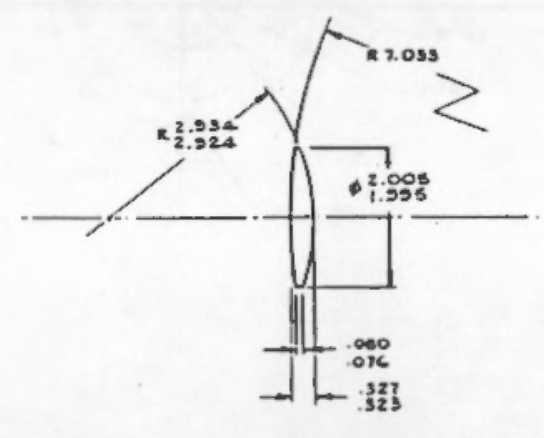

(27) LENS, $20 T$ TOM
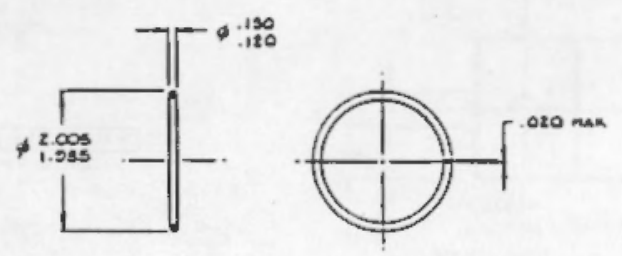

24) $S P A C E R$

mall: 200 sckits

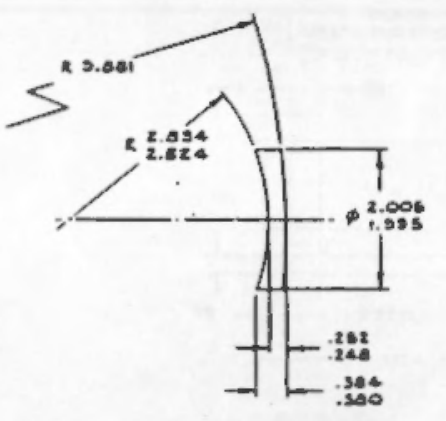

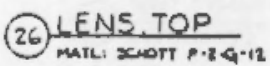
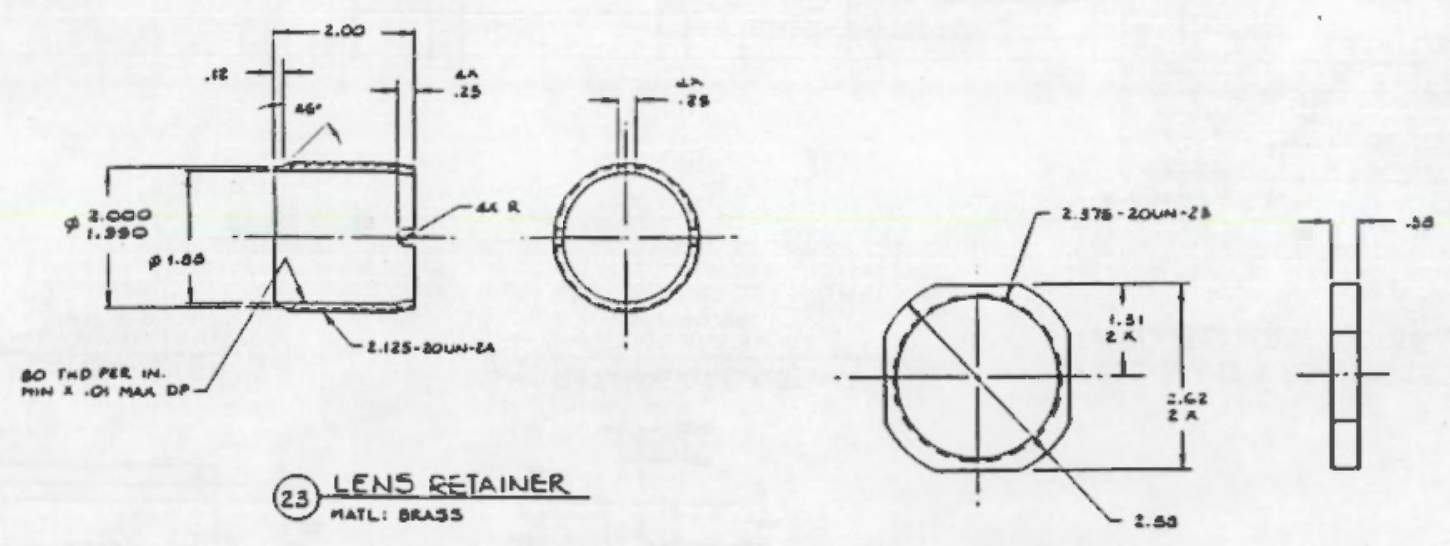

(25) JAM NUT

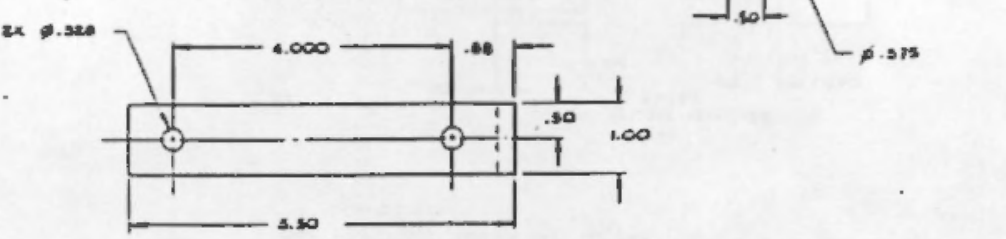

(29) PLATE.ADUUSTING

SEE SHEET I FOR PARTS LIST AND GENERAL NOTES

200. ISSUE 6.3-9. $=2$ MELTER VIEWINE SYSTEM

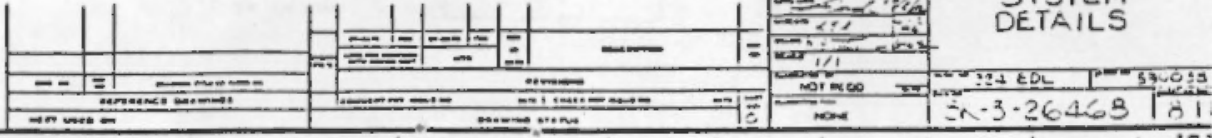

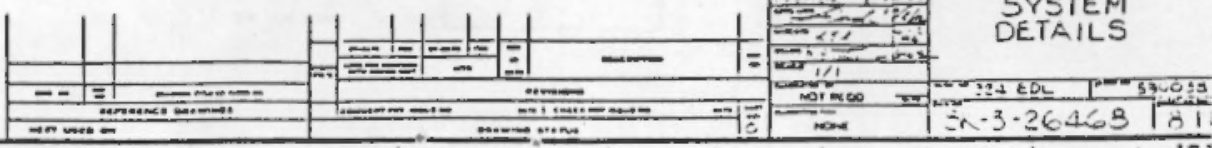

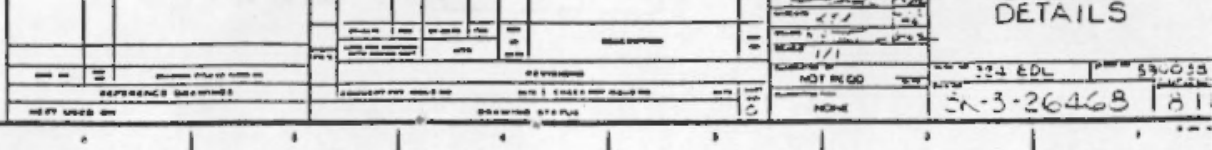




\section{DISTRIBUTION}

No. of

Copies

OFFSITE

30 DOE Technical Information Center

6 DOE office of Civilian

Radioact ive Waste Management Forrestal Building

Washington, DC 20585

ATTN: L. H. Barrett, RW-33

C. R. Cooley, RH-40

J. R. Hilley, RW-30

S. Kale, RW-20

D. E. Sheldor, RH-32

R. Stein, RW-23

4 DoE Office of Defense Waste \& GTN

Transportation Managenent

Washington, $\mathrm{OC} 20545$

ATTN: T. C. Chee, DP -123

K. A. Chorey, DP-123

G. H* Daly, DP -124

J. E. Lyt le, DP-12

4 DOE Office of Remedial Action and Waste Technology GTN

Washington, $D C 20545$

ATTN: J, A. Coleman, NE-24

T. W. McIntosh, NE-24

W. R. Voight, NE-20

H. F. Walter, NE-24

A. T. Clark

Division of Fuel Material Safety

Nuclear Regulatory Conmission

Washington, DC 20555

V. 5 tello

office of the Executive

Director for Operations

Mail Station 6209

Nuclear Regulatory Commission

Washington, DC 20555
No. of

Copies

S. Meyers

Environmental Protection Agency

Office of Radiation Prograns

(ANR-458)

401 M street, S.H.

Washington, DC 20460

J. M. McGough

DOE Albuquerque Operations Office

P.0. Box 5400

Albuquerque, NM 87185

P. G. Hagan

Joint Integration office

Carlmont Executive 1

$430 B$ Carlisle N.E.

Albuquerque, NAM 87107

E. Maestas

DOE West Valley Project office

P.O. Box 191

West Valley, NY 14171

F. T. Fong

DOE San Francisco Operations

133 Broadway

Oakland, $C A 94612$

M. R. Jugan

DOE Oak Ridge Operations Office P.0. Box E

Oak Ridge, TN 37830

W. J. Brumley

DOE Savannah River Operations office

P.O. Box A

Aiken, SC 29801

M. J. Steindler

Argonne National Laboratory

9700 South Cass Ayenue

Argonne, IL 60439 
No. of

Copies

C. \$. Abrams

Argonne National Laboratory

P.0. Box 2528

Idaho Falls, id 83401

3 Battelle Memorial Institute Project Management Division 505 King Avenue

Columbus, OH 43201

ATTV: H. A. Carbeiner

W. S. Madia

Technical Library

L. D. Ramspott

Lawrence Livermore National Laboratory

University of California

P.0. Box 808

Livermore, CA 94550

D. T, Oakley, MS 619

Los Alamos Scientific Laboratory

P.0. Box 1663

Los Alamos, NM 87544

4 Oak Ridge National Laboratory

P.0. BoX Y

Oak Ridge, rN 37830

ATTN: J. 0. Blomeke

W. D. Burch

R. T. Jubin

L. J. Mezga

Sandia Laboratories

Technical Library

P.0. Box 5800

Albuquerque, NH 87185

ATTN: R. W. Lynch

J. R. Berreth

Westinghouse Idaho Nuclear

Co. Inc.

P.0. Box 4000

Idaho Falls, in 83401
No. of

Copies

6 E. I. du Pont de Nemours Company

Savarnah River Laboratory

Aiken, SC 29801

ATTN: R. G. Baxter

M. D. Boersma

J. G. Glasscock

d. R. Knight

M. J. Plodinec

C. T. Randall

E. A. Jennrich

EG\&G Idaho

P.0. Box 1625

Idaho Falls, ID 83415

R. Shaw

Electric Power Research Institute

3412 Hillyiew Avenue

P.0. Box 10412

Palo Alto, CA 94304

5 Hest Valley Nuclear Services

Company

P. 0. Box 191

Hest Valley, NY 14171

ATTH: C. C. Chapman

J. C. Cwynar

J. E. Krauss

5. J. Marchette

J. M. Pope

J. L. White, Chairman

Energy Research \& Development Authority

Empire State Plaza

Albany, NY 12223

QNSITE

11 GoE Richland Operations offle

E. A* Bracken

C. E. Collantes

C. R. Delannoy

J. R. Hunter 
No. of

Copies

DOE Richland Operations Office (contd)

N. T. Karagianes

O. L. Lee

J. M. Peterson

J. L. Rhoades

A. J. Rizzo

M. W. Shupe

J. J. Sutey

7 Westinghouse Hanford Company

J. M. Henderson

R. E. Lerch

H. E. McGuire

J. L. Scott

D. D. Wodrich

R. D. Wojtasek

B. A. Wolfe

41 Pacific Northwest Laboratory

C. R. Allen

W. W. Ballard, Jr.

W. F. Bonner

D. J. Bradley

R. A. Brouns (5)

G. H. Bryan
No. of

Copies

Pacific Northwest Laboratory (contd)

H. C. Burkholder

J. R. Carrell

T. T. Claudson

R. D. Dierks

M. R. Elmore

R. W. Goles

W. 0 . Heath

R. S. Kemper

D. E. Knowlton

M. R. Kreiter/J. E. Mendel

W. L. Kuhn

W. W. Laity

L. T. Lakey

D. E. Larson

J. L. McElroy

R. K. Nakoaka

J. M. Perez, Jr.

M. E. Peterson

J. A. Powell

W. A. Ross

G. J. Sevigny

D. H. Siemens

S. C. Slate

J. H. Westsik, Jr.

Publishing Coordination (2)

Technical Report Files (5) 


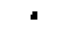

